This document was prepared in conjunction with work accomplished under Contract No. DE-AC09-96SR18500 with the U. S. Department of Energy.

\title{
DISCLAIMER
}

This report was prepared as an account of work sponsored by an agency of the United States Government. Neither the United States Government nor any agency thereof, nor any of their employees, nor any of their contractors, subcontractors or their employees, makes any warranty, express or implied, or assumes any legal liability or responsibility for the accuracy, completeness, or any third party's use or the results of such use of any information, apparatus, product, or process disclosed, or represents that its use would not infringe privately owned rights. Reference herein to any specific commercial product, process, or service by trade name, trademark, manufacturer, or otherwise, does not necessarily constitute or imply its endorsement, recommendation, or favoring by the United States Government or any agency thereof or its contractors or subcontractors. The views and opinions of authors expressed herein do not necessarily state or reflect those of the United States Government or any agency thereof. 


\section{FRIT DEVELOPMENT EFFORTS FOR SLUDGE BATCH 4 (SB4): MODEL-BASED ASSESSMENTS}

D.K. Peeler

T.B. Edwards

March 2005

Immobilization Technology Section Savannah River National Laboratory Aiken, SC 29808 
WSRC-TR-2005-00103

Revision 0

\section{DISCLAIMER}

\section{This report was prepared by Westinghouse Savannah River Company (WSRC) for the} United States Department of Energy under Contract No. DE-AC09-96SR18500 and is an account of work performed under that contract. Neither the United States Department of Energy, nor WSRC, nor any of their employees makes any warranty, expressed or implied, or assumes any legal liability or responsibility for the accuracy, completeness, or usefulness, of any information, apparatus, or product or process disclosed herein or represents that its use will not infringe privately owned rights. Reference herein to any specific commercial product, process, or service by trademark, name, manufacturer or otherwise does not necessarily constitute or imply endorsement, recommendation, or favoring of same by WSRC or by the United States Government or any agency thereof. The views and opinions of the authors expressed herein do not necessarily state or reflect those of the United States Government or any agency thereof.

\section{Printed in the United States of America \\ Prepared For U.S. Department of Energy}

The Savannah River National Laboratory is operated for the U.S. Department of Energy by Westinghouse Savannah River Company. 
Key Words: $D W P F$, projected operating windows, sulfate

Retention: Permanent

\section{FRIT DEVELOPMENT EFFORTS FOR SLUDGE BATCH 4 (SB4): MODEL-BASED ASSESSMENTS}

D.K. Peeler

T.B. Edwards

March 2005

Immobilization Technology Section Savannah River National Laboratory Aiken, SC 29808

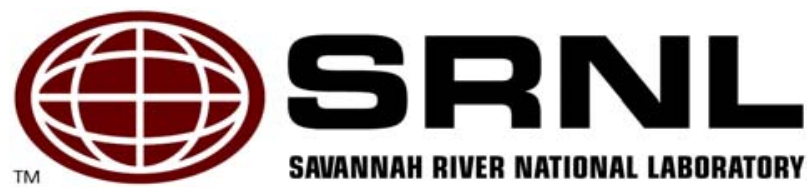




\section{REVIEWS AND APPROVALS}

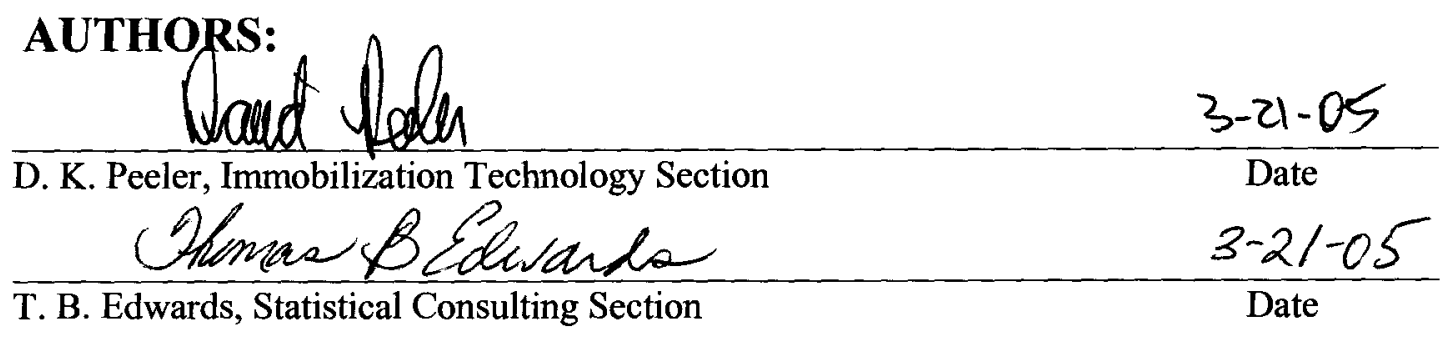

TECHNICAL REVIEWER:

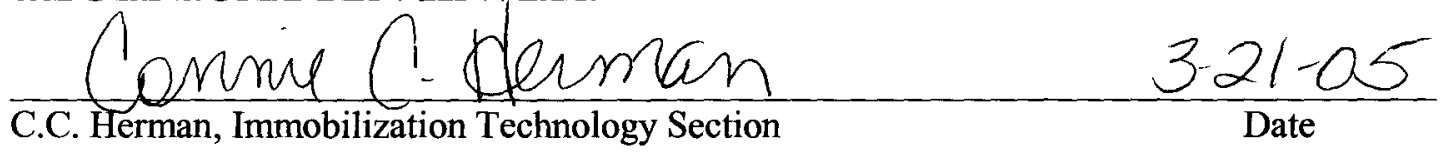

\section{APPROVERS:}

Zn ftaetretents

E. W. Holtzscheifer, Manager, Immobilization Technology Section Shanon forlawa

S. L. Marra, Manager, Glass Formulation \& Process Development

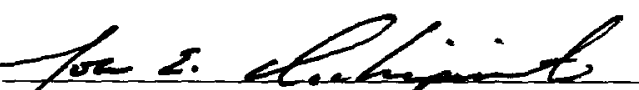

Y. E. Occhipinti, Manager, DWPF Process Engineering
$3-2+200)^{-}$

Date

$3 / 23 / 05$

Date

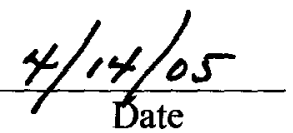


WSRC-TR-2005-00103

Revision 0

\section{EXECUTIVE SUMMARY}

The model-based assessments of nominal Sludge Batch 4 (SB4) compositions suggest that a viable frit candidate does not appear to be a limiting factor as the Closure Business Unit (CBU) considers various tank blending options and/or washing strategies. This statement is based solely on the projected operating windows derived from model predictions and does not include assessments of $\mathrm{SO}_{4}$ solubility or melt rate issues. The viable frit candidates covered a range of $\mathrm{Na}_{2} \mathrm{O}$ concentrations (from $8 \%$ to $13 \%$ - including Frit 418 and Frit 320) using a "sliding $\mathrm{Na}_{2} \mathrm{O}$ scale" concept (i.e., $1 \%$ increase in $\mathrm{Na}_{2} \mathrm{O}$ being balanced by a $1 \%$ reduction in $\mathrm{SiO}_{2}$ ) which effectively balances the alkali content of the incoming sludge with that in the frit to maintain and/or increase the projected operating window size while potentially leading to improved melt rate and/or waste loadings. This strategy or approach allows alternative tank blending strategies and/or different washing scenarios to be considered and accounted for in an effective manner without wholesale changes to the frit composition.

In terms of projected operating windows, in general, the sludge / frit systems evaluated resulted in waste loading intervals from 25 to the mid- $40 \%$ 's or even the mid-50\%'s. The results suggest that a single frit could be selected for use with all 20 options which indicates some degree of frit robustness with respect to sludge compositional variation. In fact, use of Frit 418 or Frit 320 (the "cornerstone" frits given previous processing experience in the Defense Waste Processing Facility (DWPF)) are plausible for most (if not all) options being considered. However, the frit selection process also needs to consider potential processing issues such as melt rate. Based on historical trends between melt rate and total alkali content, one may elect to use the frit with the highest alkali content that still yields an acceptable operating window. However, other constraints may restrict access to higher waste loading or the proposed blending option being considered (e.g., sulfate content of the high-level waste and/or Chemical Processing Cell (CPC) issues may necessitate a more-washed sludge). 


\section{TABLE OF CONTENTS}

\begin{tabular}{|c|c|}
\hline 1.0 & 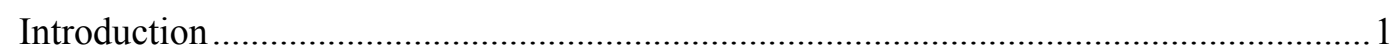 \\
\hline 2.0 & Objective ..................................... \\
\hline 3.0 & 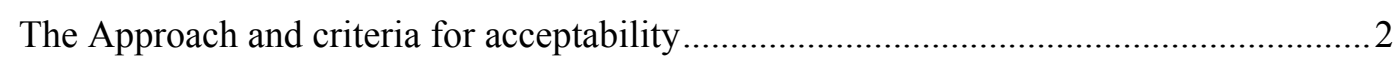 \\
\hline 4.0 & 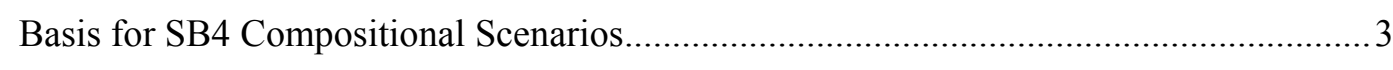 \\
\hline 4.1 & 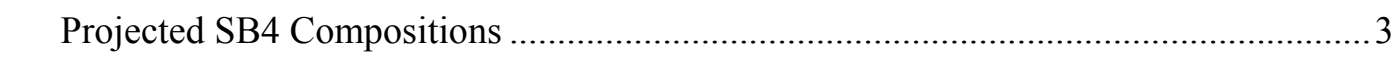 \\
\hline 4.2 & 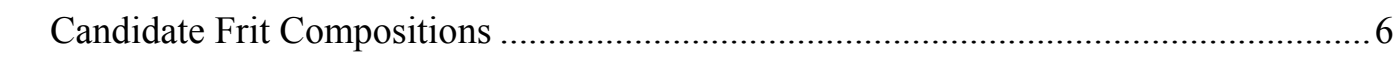 \\
\hline 5.0 & 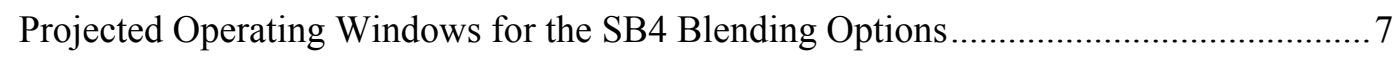 \\
\hline 5.1 & SB4-Only \\
\hline 5.2 & 1100 Canister Options .......................... \\
\hline 5.3 & 1200 Canister Options ...................... \\
\hline 5.4 & Impact of the $\mathrm{SO}_{4}$ Solubility Limit ....... \\
\hline 5.5 & Frittability of Candidate Frits .................................. \\
\hline 5.6 & Impact of Washing ................................... \\
\hline 6.0 & Summary .......................... \\
\hline 7.0 & References .............................. \\
\hline 8.0 & Appendix A. \\
\hline
\end{tabular}




\section{LIST OF ACRONYMS}

$\begin{array}{ll}\text { ASTM } & \text { American Society for Testing and Materials } \\ \text { CBU } & \text { Closure Business Unit } \\ \text { CPC } & \text { Chemical Processing Cell } \\ \text { DWPF } & \text { Defense Waste Processing Facility } \\ \Delta G_{P} & \text { preliminary glass dissolution estimator } \\ \text { MAR } & \text { Measurement Acceptability Region } \\ \text { NL [B] } & \text { normalized boron release (in g/L) } \\ \text { PCCS } & \text { Product Composition Control System } \\ \text { PCT } & \text { Product Consistency Test } \\ \text { SB } & \text { sludge batch } \\ \text { SME } & \text { Slurry Mix Evaporator } \\ \text { SRAT } & \text { Sludge Receipt and Adjustment Tank } \\ \text { SRNL } & \text { Savannah River National Laboratory } \\ \text { SRS } & \text { Savannah River Site } \\ \text { T } & \text { liquidus temperature } \\ \eta & \text { viscosity } \\ \text { WL } & \text { waste loading } \\ \text { WSRC } & \text { Westinghouse Savannah River Company } \\ & \end{array}$




\section{LIST OF TABLES}

Table 4-1. SB4 Blending Options - as Elemental Concentrations (wt\%) (from Lilliston (2005)) ........ 4

Table 4-2. SB4 Blending Options -as Normalized Oxide Concentrations (wt \%)............................ 5

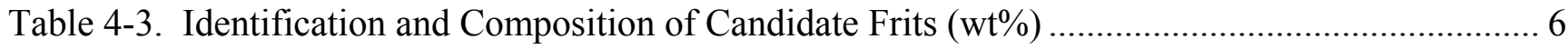

Table 5-1. SB4 Only Options - MAR Results ........................................................................... 8

Table 5-2. 1100 Canister Options - MAR Results ........................................................................ 9

Table 5-3. 1200 Canister Options - MAR Results .................................................................... 12

Table 5-4. Maximum WLs for Each SB4 Options as a Function of the $\mathrm{SO}_{4}$ Solubility Limit............ 13

Table 5-5. 1100 Canister Baseline Option - MAR Results with $\mathrm{SO}_{4}$ Activated............................... 14

Table 5-6. SB4 Blending Options - "1 Less Wash" as Normalized Oxide Concentrations (wt\%)...... 16

Table 5-7. Impact of Washing Strategy on Operating Windows for SB4-Only Options - MAR Results

Table 5-8. Impact of Washing Strategy on Operating Windows for 1100 Canister Options - MAR

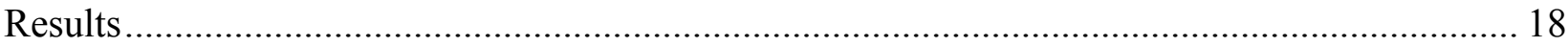

Table 5-9. Impact of Washing Strategy on Operating Windows for 1200 Canister Options - MAR

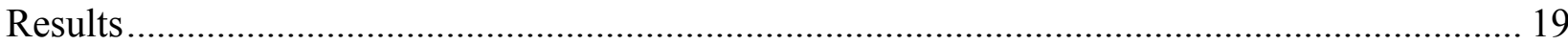

Table 5-10. Impact of Washing on the 1100 Canister Baseline Sludge Options.............................. 20 


\subsection{INTRODUCTION}

The Defense Waste Processing Facility (DWPF) is currently processing Sludge Batch 3 (SB3) as a "sludge-only" composition by combining SB3 with Frit 418, melting the slurry mix of sludge and frit, and pouring the molten glass in stainless steel canisters to create the final waste form for this high-level waste at the Savannah River Site (SRS). In preparation for the qualification and receipt of the next sludge batch, Sludge Batch 4 (SB4), development and definition of the baseline flowsheet have been initiated (Lilliston 2005). Various tank blending strategies are being contemplated for SB4 in an effort to meet critical Closure Business Unit (CBU) objectives including issues associated with the durability of the DWPF glass waste form and the efficiency and effectiveness of the DWPF operation. Critical components of DWPF's operational efficiency and effectiveness include sludge/frit processability, melter attainment (the percentage of time DWPF's melter is pouring), melt rate, waste loading, and canister production rates. An early yet meaningful assessment of the processability of a sludge option and of the durability of the final waste form for candidate frits at various waste loadings is provided by using predictions generated by property/composition models. The models employed are the same as those used by DWPF's Product Composition Control System (PCCS), and this investigation of candidate sludge/frit glass systems may be described as a paper study whose purpose is to identify a viable frit or frits for each sludge option being contemplated. A frit is considered viable if its composition allows for economic fabrication and if, when it is combined with a sludge option under consideration, DWPF's property/composition models indicate that the combination has an operating window (a waste loading interval over which the sludge/frit glass system satisfies processability and durability constraints) that allows DWPF to meet its goals for waste loading and canister production.

The Savannah River National Laboratory (SRNL) has been asked via a technical task request (Washburn 2004) to provide frit development support for SB4. In response, SRNL has issued a task technical and quality assurance plan (Peeler 2004), and it is under the auspices of that plan that this report has been prepared. The purpose of this report is to identify candidate frits and to assess their viability for the 20 options being contemplated for SB4 as provided by Lilliston (2005). The assessments performed are strictly model-based, and no experimental work was conducted to support this task. Specifically, no experiments on melt rate were conducted for the systems explored. Although not included in the scope of this report, such experimental work is planned as part of the support for SB4 (Peeler and Smith 2004) since the results from melt rate studies are a critical input to the final selection of a frit for SB4.

This report summarizes the assessments of 20 SB4 tank blending scenarios that were provided by the CBU. Candidate frits were identified based on a review of each projected sludge composition and assessed using model-based predictions to project operational windows. It should be noted that only the Nominal Stage assessment was performed. That is, given the large number of options, the Variation Stage which introduces variation around the nominal SB4 compositions in an effort to gain insight into the robustness or tolerance of a candidate frit to anticipated compositional variation was not performed. ${ }^{1}$ The information resulting from these efforts will provide part of the technical basis for selecting the blending and/or washing strategy for SB4 processing. It should be noted that a parallel activity is being performed to address other operational issues associated with Sludge Receipt and Adjustment Tank (SRAT) / Slurry Mix Evaporator (SME) processing (e.g., $\mathrm{H}_{2}$ generation issues and acid addition and redox control strategies). Therefore, the results from both

\footnotetext{
${ }^{1}$ Although the Variation Stage was not performed, the 20 nominal SB4 blending options provided by Lilliston (2005) will provide some insight into the ability of a specific frit composition to tolerate some degree of sludge compositional variation.
} 
tasks, as well as melt rate assessments, should be considered prior to formalizing a decision regarding a baseline flowsheet for SB4.

Objectives for this task are specified in Section 2.0. In Section 3.0, a brief review of the strategy or approach for developing and assessing new or existing frits is provided as well as the criteria used to make acceptability decisions. Projected SB4 nominal compositions are summarized in Section 4.0 from which the assessments will be founded. Section 5.0 summarizes the Nominal Stage, Measurement Acceptability Region (MAR) based assessments for the 20 SB4 blending scenarios. Section 6.0 provides a summary of these assessments.

\subsection{OBJECTIVE}

The objective of this task is to provide technical information to the DWPF from which a business decision can be made in terms of identifying candidate frit compositions for the SB4 flowsheet. The information provided in this report is solely focused on model-based projections of the PCCS operational windows for various SB4 blending strategies of interest. Experimental assessments of melt rate or $\mathrm{SO}_{4}$ solubility are not addressed in this report but are being addressed in parallel tasks.

\subsection{THE APPROACH AND CRITERIA FOR ACCEPTABILITY}

To meet the programmatic objectives, the Nominal Stage assessments as proposed by Peeler and Edwards (2002) were used to assess various frit/sludge combinations. The assessment utilized nominal SB4 compositions representing potential tank blending scenarios as outlined by Lilliston (2005). In general, this stage assessed candidate frit compositions with respect to their ability to provide a relatively large projected operating window based solely on a specific nominal composition - no sludge variation was accounted for in this phase. Assessments were made using predictions from models currently implemented in DWPF's PCCS over the waste loading (WL) interval of interest $(25-60 \mathrm{wt} \%)$. The primary property predictions assessed included those for liquidus temperature $\left(T_{L}\right)$, viscosity $(\eta)$, and durability (normalized boron release $-N L[B]$ ).

It is recognized that the Nominal Stage assessments do not account for anticipated compositional variation. However, the compositional projections provided by Lilliston (2005) were based on various percentages of possible tanks that could represent or be included in SB4, along with different heel volumes for SB3. The selected compositions also specifically targeted upper and lower bounds for DWPF affecting elements. Therefore, the compositions do represent or provide a measure of sludge variation that provides some insight into the robustness of candidate frits with respect to compositional variation. If needed, and as the SB4 flowsheet becomes more mature (primary blending options are defined), a formal Variation Stage assessment could be performed to address this issue.

As previously mentioned, the property predictions assessed in this study included durability (Product Consistency Test [PCT] [ASTM 2002] response in terms of the preliminary glass dissolution estimator $\left(\Delta \mathrm{G}_{\mathrm{P}}\right)\left(\right.$ Jantzen et al. 1995)), viscosity at $1150^{\circ} \mathrm{C}\left(\eta_{1150^{\circ} \mathrm{C}}\right), \mathrm{T}_{\mathrm{L}}$, and $\mathrm{Al}_{2} \mathrm{O}_{3}$ and alkali concentrations. Jantzen et al. (1995) and Brown et al. (2001) provide a more detailed discussion on the development of these models. To establish or project operational windows for sludge/frit scenarios of interest, the predicted properties must be assessed relative to established acceptance criteria. Acceptable predicted properties for this assessment were based on satisfying their respective 
MAR limit values. Brown, Postles, and Edwards (2002) provide a detailed discussion of how the MAR limits are utilized in PCCS.

Although the $\mathrm{SO}_{4}$ limit for SB4 has not been established, various $\mathrm{SO}_{4}$ limits can be used (e.g., 0.4, 0.5 , and $0.6 \mathrm{wt} \%$ in glass) to assess if $\mathrm{SO}_{4}$ will have a negative impact on the projected operating window. The $\mathrm{SO}_{4}$ concentrations in glass will be calculated, but an assumed $\mathrm{SO}_{4}$ limit will not be used to restrict the projected operating windows based on the model predictions. Given there is no MAR uncertainty associated with the $\mathrm{SO}_{4}$ concentration, the maximum WL for each SB4 option can be determined as a function of an assumed $\mathrm{SO}_{4}$ solubility limit based strictly on mathematics (i.e., the assumed $\mathrm{SO}_{4}$ solubility limit divided by the $\mathrm{SO}_{4}$ concentration in sludge times 100 ). For example, if the $\mathrm{SO}_{4}$ concentration in sludge was $1.09 \mathrm{wt} \%$ and the assumed $\mathrm{SO}_{4}$ solubility limit was $0.4 \mathrm{wt} \%$ (in glass), then the maximum WL achievable (based strictly on the $\mathrm{SO}_{4}$ solubility limit) would be $\sim 36.7$ wt $\%$. If the $\mathrm{SO}_{4}$ solubility limit was $0.5 \mathrm{wt} \%$, then the maximum achievable WL ((based strictly on the $\mathrm{SO}_{4}$ solubility limit) would be $45.9 \%$. Although one can easily calculate the maximum WL for a given $\mathrm{SO}_{4}$ solubility limit, properties other than $\mathrm{SO}_{4}$ solubility may restrict access to higher WLs. Therefore, a nominal $\mathrm{SO}_{4}$ value has been added to each of the 20 options but a $\mathrm{SO}_{4}$ solubility limit in PCCS was not activated with respect to limiting or imposing restrictions on the MAR based assessments for the initial assessments.

\subsection{BASIS FOR SB4 COMPOSITIONAL SCENARIOS}

Two primary inputs are required to assess the projected operating windows, the waste loading intervals and the robustness to compositional variation. The primary inputs are: sludge (or waste stream) and frit composition(s). Given the focus of this study is to develop and assess frit compositions for SB4, defining the nominal SB4 waste stream(s) is the only required input. For a given waste stream composition, one can select candidate frit compositions and ultimately assess or define glass compositional regions or operating windows based on established acceptance criteria.

\subsection{Projected SB4 Compositions}

Table 5-1 provides the elemental compositions (in weight percent, $\mathrm{wt} \%$ ) of the 20 options outlined by Lilliston (2005) for SB4. It should be noted that Lilliston (2005) did not report anion concentrations (in particular $\mathrm{SO}_{4}$ which is anticipated to be relatively high in SB4). Additional information obtained from the $\mathrm{CBU}$ provided a technical basis for a projected $\mathrm{SO}_{4}$ concentration $(\sim 1.09 \mathrm{wt} \%$ in calcined sludge solids) in SB4 based on the baseline flowsheet. Although Lilliston (2005) did not incorporate $\mathrm{SO}_{4}$ into the 20 options, this study will utilize the nominal $1.09 \mathrm{wt} \%$ value (pre-normalized) in order to assess the potential impact of $\mathrm{SO}_{4}$ solubility on the projected operating windows. ${ }^{2}$ That is, the elemental compositions provided by Lilliston (2005) were converted to oxides by multiplying the concentrations by the appropriate gravimetric factor. The $1.09 \mathrm{wt} \% \mathrm{SO}_{4}$ was then added to this list of oxides. The oxide compositions were then normalized to sum to $100 \mathrm{wt} \%$ for each of the 20 options. The resulting normalized oxide compositions for each of the twenty sludge options are shown in Table 5-2. It should be noted that the $\mathrm{SO}_{4}$ concentration for each of the 20 options is not "constant" given the sum of oxide differences among the various options prior to normalization.

\footnotetext{
${ }^{2}$ Shah et.al. (2004) provided the nominal supernate composition for SB4, which included sulfate. For this study, all of the sulfate was assumed to be soluble and the sulfate in the calcined solids was estimated to be $1.09 \mathrm{wt} \%$ assuming a calcine factor similar to that seen for SB4 simulant flowsheet testing.
} 
Table 4-1. SB4 Blending Options - as Elemental Concentrations (wt\%) (from Lilliston (2005))

\begin{tabular}{|c|c|c|c|c|c|c|c|c|c|c|c|c|c|c|c|c|c|c|c|c|}
\hline & $\begin{array}{c}\text { SB4 } \\
\text { Only } \\
\text { Baseline }\end{array}$ & \begin{tabular}{|c|} 
SB4 Only \\
Min Al, \\
$\mathrm{Na}, \mathrm{Mg}$, \\
$\mathrm{Ti} ; \mathrm{Max}$ \\
$\mathrm{Ce}, \mathrm{Fe}$, \\
$\mathrm{Mg}, \mathrm{Ni}, \mathrm{U}$ \\
\end{tabular} & \begin{tabular}{|c|} 
SB4 Only \\
Max Al, \\
$\mathrm{Na}, \mathrm{Mg}$, \\
$\mathrm{Ti} ; \mathrm{Min} \mathrm{Ce}$, \\
$\mathrm{Fe}, \mathrm{Mn}, \mathrm{Ni}$, \\
$\mathrm{U}$ \\
\end{tabular} & $\begin{array}{c}1100 \\
\text { Can } \\
\text { Baseline }\end{array}$ & \begin{tabular}{|c}
1100 \\
Can 2nd \\
Transfer, \\
Baseline
\end{tabular} & \begin{tabular}{|c|}
1100 \\
$\mathrm{Can} \mathrm{Min}$ \\
$\mathrm{Al}, \mathrm{Na}$ \\
$\mathrm{Max} \mathrm{Ce}$, \\
$\mathrm{Fe}, \mathrm{Mn}$, \\
$\mathrm{U}$ \\
\end{tabular} & \begin{tabular}{|c|}
1100 \\
Can Max \\
$\mathrm{Al}, \mathrm{Na} ;$ \\
$\mathrm{Min} \mathrm{Mn}$, \\
$\mathrm{Ni}, \mathrm{U}$ \\
\end{tabular} & $\begin{array}{c}1100 \\
\mathrm{Can} \mathrm{Min} \\
\mathrm{Ce}, \mathrm{Mg}, \\
\mathrm{Ti}\end{array}$ & $\begin{array}{c}1100 \\
\text { Can Min } \\
\text { Fe }\end{array}$ & $\begin{array}{c}1100 \\
\text { Can Max } \\
\text { Mg }\end{array}$ & $\begin{array}{c}1100 \\
\text { Can Max } \\
\mathrm{Ni}\end{array}$ & $\begin{array}{c}1100 \\
\text { Can Max } \\
\mathrm{Ti}\end{array}$ & $\begin{array}{c}1200 \\
\text { Can } \\
\text { Baseline }\end{array}$ & \begin{tabular}{|c|}
1200 \\
Can 2nd \\
Transfer, \\
Baseline
\end{tabular} & \begin{tabular}{|c|}
1200 \\
$\mathrm{Can} \mathrm{Min}$ \\
$\mathrm{Al}, \mathrm{Na}$ \\
$\mathrm{Max} \mathrm{Ce}$ \\
$\mathrm{Fe}, \mathrm{Mn}$, \\
$\mathrm{U}$ \\
\end{tabular} & \begin{tabular}{|c|}
1200 \\
$\mathrm{Can} \mathrm{Max}$ \\
$\mathrm{Al}, \mathrm{Na} ;$ \\
$\mathrm{Min} \mathrm{Fe}$, \\
$\mathrm{Mn}, \mathrm{Ni}$, \\
$\mathrm{U}$ \\
\end{tabular} & $\begin{array}{c}1200 \\
\text { Can Max } \\
\mathrm{Ni}\end{array}$ & $\begin{array}{c}1200 \\
\text { Can Min } \\
\text { Ce }\end{array}$ & $\begin{array}{c}1200 \\
\text { Can Min } \\
\mathrm{Mg}, \mathrm{Ti}\end{array}$ & $\begin{array}{c}1200 \\
\mathrm{Can} \mathrm{Max} \\
\mathrm{Mg}, \mathrm{Ti}\end{array}$ \\
\hline Cation & $\mathrm{wt} \%$ & wt $\%$ & \begin{tabular}{|l|}
$\mathrm{wt} \%$ \\
\end{tabular} & wt $\%$ & $\mathrm{wt} \%$ & $w t \%$ & $\mathrm{wt} \%$ & $\mathrm{Wt} \%$ & $\mathrm{wt} \%$ & $\mathrm{wt} \%$ & $\mathrm{wt} \%$ & $\mathrm{wt} \%$ & $\mathrm{wt} \%$ & $\mathrm{wt} \%$ & $w t \%$ & wt $\%$ & $\mathrm{wt} \%$ & $\mathrm{wt} \%$ & $\mathrm{wt} \%$ & $\mathrm{wt} \%$ \\
\hline $\mathrm{Al}$ & 16.319 & 13.486 & 24.268 & 11.908 & 13.209 & 10.267 & 16.472 & 13.947 & 14.932 & 11.374 & 11.807 & 14.890 & 12.747 & 13.433 & 10.824 & 17.366 & 11.824 & 15.034 & 13.852 & 15.801 \\
\hline $\mathrm{Ba}$ & 0.166 & 0.202 & 0.071 & 0.144 & 0.150 & 0.158 & 0.095 & 0.165 & 0.139 & 0.144 & 0.178 & 0.101 & 0.147 & 0.150 & 0.165 & 0.092 & 0.178 & 0.139 & 0.164 & 0.097 \\
\hline $\mathrm{Ca}$ & 1.177 & 1.134 & 1.210 & 1.584 & 1.442 & 1.611 & 1.559 & 1.271 & 1.354 & 1.605 & 1.343 & 1.644 & 1.491 & 1.417 & 1.512 & 1.510 & 1.339 & 1.343 & 1.282 & 1.593 \\
\hline $\mathrm{Ce}$ & 0.161 & 0.159 & 159 & 0.176 & 0.170 & 0.178 & 0.173 & 0.162 & 0.164 & 0.176 & 0.166 & 0.177 & 0.172 & 0.169 & 0.173 & 0.170 & 0.165 & 0.163 & 0.162 & 0.174 \\
\hline $\mathrm{Cr}$ & 0.194 & 0.206 & 0.160 & 0.171 & 0.177 & 0.175 & 0.155 & 0.186 & 0.174 & 0.169 & 0.189 & 0.154 & 0.175 & 0.178 & 0.179 & 0.154 & 0.189 & 0.174 & 0.185 & 0.154 \\
\hline $\mathrm{Cu}$ & 0.063 & 0.067 & 0.045 & 0.066 & 0.065 & 0.069 & 0.056 & 0.063 & 0.059 & 0.065 & 0.067 & 0.059 & 0.065 & 0.064 & 0.068 & 0.055 & 0.067 & 0.058 & 0.063 & 0.057 \\
\hline $\mathrm{Fe}$ & 14.160 & 15.310 & 10.457 & 18.051 & 16.678 & 18.994 & 15.685 & 15.420 & 15.359 & 18.415 & 16.842 & 16.902 & 17.153 & 16.432 & 18.205 & 14.988 & 16.813 & 15.252 & 15.522 & 16.188 \\
\hline $\mathrm{K}$ & 1.574 & 1.239 & 2.501 & 0.844 & 1.068 & 0.627 & 1.397 & 1.227 & 1.288 & 0.747 & 0.936 & 1.168 & 0.987 & 1.106 & 0.737 & 1.525 & 0.939 & 1.303 & 1.209 & 1.298 \\
\hline $\mathrm{La}$ & 0.067 & 0.068 & 0.057 & 0.079 & 0.074 & 0.081 & 0.072 & 0.069 & 0.069 & 0.078 & 0.073 & 0.076 & 0.075 & 0.073 & 0.078 & 0.070 & 0.073 & 0.068 & 0.069 & 0.073 \\
\hline $\mathrm{Mg}$ & 0.211 & 0.201 & 0.243 & 1.162 & 0.852 & 1.258 & 1.090 & 0.525 & 0.748 & 1.285 & 0.694 & 1.278 & 0.964 & 0.800 & 1.056 & 0.984 & 0.689 & 0.729 & 0.551 & 1.171 \\
\hline $\mathrm{Mn}$ & 3.941 & 4.568 & 490 & 4.486 & 4.278 & 4.826 & 3.656 & 4.248 & 4.125 & 4.693 & 4.631 & 3.928 & 4.360 & 4.249 & 4.765 & 3.511 & 4.634 & 4.117 & 4.265 & 3.783 \\
\hline $\mathrm{Na}$ & 14.720 & 14.348 & 15.643 & 16.214 & 16.200 & 16.043 & 16.749 & 16.076 & 16.297 & 16.170 & 15.899 & 16.653 & 16.205 & 16.197 & 15.991 & 16.797 & 15.897 & 16.298 & 16.078 & 16.701 \\
\hline $\mathrm{Ni}$ & 4.574 & 6.083 & 0.965 & 2.896 & 3.404 & 3.387 & 1.130 & 4.370 & 3.319 & 2.951 & 4.743 & 1.172 & 3.223 & 3.491 & 3.872 & 1.107 & 4.755 & 3.347 & 4.321 & 1.148 \\
\hline $\mathrm{Pb}$ & 0.184 & 0.160 & 0.242 & 0.153 & 0.161 & 0.139 & 0.185 & 0.163 & 0.168 & 0.145 & 0.148 & 0.174 & 0.158 & 0.162 & 0.142 & 0.191 & 0.148 & 0.168 & 0.163 & 0.180 \\
\hline $\mathrm{Si}$ & 1.117 & 0.951 & 1.549 & 1.267 & 1.210 & 1.214 & 1.478 & 1.108 & 1.242 & 1.276 & 1.063 & 1.472 & 1.233 & 1.202 & 1.163 & 1.485 & 1.063 & 1.241 & 1.114 & 1.479 \\
\hline Th & 0.035 & 0.027 & 0.057 & 0.030 & 0.032 & 0.027 & 0.042 & 0.031 & 0.036 & 0.030 & 0.026 & 0.040 & 0.031 & 0.032 & 0.026 & 0.044 & 0.026 & 0.035 & 0.031 & 0.041 \\
\hline $\mathrm{Ti}$ & 0.008 & 0.006 & 0.013 & 0.013 & 0.011 & 0.012 & 0.015 & 0.009 & 0.011 & 0.013 & 0.009 & 0.015 & 0.012 & 0.011 & 0.011 & 0.015 & 0.009 & 0.011 & 0.009 & 0.015 \\
\hline $\mathrm{U}$ & 7.238 & 9.447 & 0.974 & 7.805 & 7.564 & 8.841 & 4.417 & 7.793 & 6.450 & 7.895 & 9.044 & 5.184 & 7.653 & 7.526 & 8.917 & 3.990 & 9.047 & 6.422 & 7.807 & 4.750 \\
\hline $\mathrm{Zn}$ & 0.091 & 0.101 & 0.051 & 0.102 & $\begin{array}{l}0.098 \\
\end{array}$ & 0.108 & 0.080 & 0.094 & 0.084 & 0.100 & 0.103 & 0.087 & 0.099 & 0.096 & 0.105 & 0.075 & 0.102 & 0.083 & 0.094 & $\begin{array}{l}0.082 \\
\end{array}$ \\
\hline $\mathrm{Zr}$ & 0.233 & 0.250 & 0.171 & 0.205 & 0.212 & 0.210 & 0.174 & 0.221 & 0.198 & 0.197 & 0.228 & 0.176 & 0.208 & 0.212 & 0.215 & 0.172 & 0.227 & 0.197 & 0.220 & 0.173 \\
\hline
\end{tabular}


Table 4-2. SB4 Blending Options -as Normalized Oxide Concentrations (wt \%) ${ }^{3}$

\begin{tabular}{|c|c|c|c|c|c|c|c|c|c|c|c|c|c|c|c|c|c|c|c|c|}
\hline & $\begin{array}{c}\text { SB4 } \\
\text { Only } \\
\text { Baseline }\end{array}$ & \begin{tabular}{|c|} 
SB4 Only \\
Min Al, \\
$\mathrm{Na}, \mathrm{Mg}$, \\
$\mathrm{Ti} ; \mathrm{Max}$ \\
$\mathrm{Ce}, \mathrm{Fe}$, \\
$\mathrm{Mg}, \mathrm{Ni}, \mathrm{U}$ \\
\end{tabular} & \begin{tabular}{|c} 
SB4 Only \\
Max Al, \\
$\mathrm{Na}, \mathrm{Mg}$, \\
$\mathrm{Ti} ; \mathrm{Min} \mathrm{Ce}$, \\
$\mathrm{Fe}, \mathrm{Mn}, \mathrm{Ni}$, \\
$\mathrm{U}$
\end{tabular} & $\begin{array}{c}1100 \\
\text { Can } \\
\text { Baseline }\end{array}$ & $\begin{array}{c}1100 \\
\text { Can 2nd } \\
\text { Transfer, } \\
\text { Baseline }\end{array}$ & \begin{tabular}{|c|}
1100 \\
Can Min \\
$\mathrm{Al}, \mathrm{Na}$ \\
$\mathrm{Max} \mathrm{Ce}$ \\
$\mathrm{Fe}, \mathrm{Mn}$, \\
$\mathrm{U}$ \\
\end{tabular} & $\begin{array}{c}1100 \\
\mathrm{Can} \mathrm{Max} \\
\mathrm{Al}, \mathrm{Na} \\
\mathrm{Min} \mathrm{Mn}, \\
\mathrm{Ni}, \mathrm{U}\end{array}$ & $\begin{array}{c}1100 \\
\text { Can Min } \\
\text { Ce, Mg, } \\
\text { Ti }\end{array}$ & $\begin{array}{c}1100 \\
\text { Can Min } \\
\text { Fe }\end{array}$ & $\begin{array}{c}1100 \\
\text { Can Max } \\
\mathrm{Mg}\end{array}$ & $\begin{array}{c}1100 \\
\text { Can Max } \\
\mathrm{Ni}\end{array}$ & $\begin{array}{c}1100 \\
\text { Can Max } \\
\mathrm{Ti}\end{array}$ & $\begin{array}{c}1200 \\
\text { Can } \\
\text { Baseline }\end{array}$ & \begin{tabular}{|c}
1200 \\
Can 2nd \\
Transfer, \\
Baseline
\end{tabular} & \begin{tabular}{|c|}
1200 \\
$\mathrm{Can} \mathrm{Min}$ \\
$\mathrm{Al}, \mathrm{Na}$; \\
$\mathrm{Max} \mathrm{Ce}$, \\
$\mathrm{Fe}, \mathrm{Mn}$, \\
$\mathrm{U}$ \\
\end{tabular} & \begin{tabular}{|c|}
1200 \\
$\mathrm{Can} \mathrm{Max}$ \\
$\mathrm{Al}, \mathrm{Na} ;$ \\
$\mathrm{Min} \mathrm{Fe}$, \\
$\mathrm{Mn}, \mathrm{Ni}$, \\
$\mathrm{U}$ \\
\end{tabular} & $\begin{array}{c}1200 \\
\text { Can Max } \\
\mathrm{Ni}\end{array}$ & $\begin{array}{c}1200 \\
\text { Can Min } \\
\text { Ce }\end{array}$ & $\begin{array}{c}1200 \\
\text { Can Min } \\
\text { Mg, Ti }\end{array}$ & $\begin{array}{c}1200 \\
\text { Can Max } \\
\mathrm{Mg}, \mathrm{Ti}\end{array}$ \\
\hline Oxide & $\mathrm{wt} \%$ & wt $\%$ & $\mathrm{wt} \%$ & $\mathrm{wt} \%$ & $\mathrm{wt} \%$ & wt $\%$ & wt $\%$ & $\mathrm{Wt} \%$ & $\mathrm{wt} \%$ & $\mathrm{wt} \%$ & $\mathrm{wt} \%$ & $\mathrm{wt} \%$ & $\mathrm{wt} \%$ & $\mathrm{wt} \%$ & $\mathrm{wt} \%$ & $w t \%$ & $\mathrm{wt} \%$ & $\mathrm{wt} \%$ & $\mathrm{wt} \%$ & $\mathrm{wt} \%$ \\
\hline $\mathrm{Al}_{2} \mathrm{O}_{3}$ & 31.074 & .590 & 46.666 & 22.675 & 25.149 & 19.523 & 31.529 & 26.528 & 28.471 & 21.659 & 22.422 & 28.476 & 24.273 & 25.576 & 20.573 & 33.258 & 22.454 & 28.666 & 26.350 & 30.234 \\
\hline $\mathrm{BaO}$ & & 26 & 081 & 162 & 68 & 177 & 108 & 185 & 157 & 162 & 0.200 & 0.114 & 0.166 & .169 & 0.185 & 0.104 & .200 & 0.157 & 0.184 & 0.110 \\
\hline $\mathrm{CaO}$ & 1.659 & 594 & 1.722 & 2.233 & 2.034 & 2.268 & 2.210 & 1.791 & 1.912 & 2.263 & 1.889 & 2.328 & 2.102 & 1.997 & 2.129 & 2.141 & 1.883 & 1.897 & 1.806 & 2.257 \\
\hline $\mathrm{Ce}_{2} \mathrm{O}_{3}$ & 190 & 187 & .189 & 0.208 & 0.201 & 0.209 & 0.205 & 0.191 & 0.194 & 0.208 & 0.195 & 0.210 & 0.203 & 0.199 & 0.203 & 0.202 & 0.195 & 0.193 & 0.191 & 0.206 \\
\hline $\mathrm{Cr}_{2} \mathrm{O}_{3}$ & 0.286 & 0.303 & 0.238 & 0.252 & 0.261 & 0.257 & 0.229 & 0.274 & 0.256 & 0.249 & 0.277 & 0.228 & 0.257 & 0.262 & 0.264 & 0.229 & 0.277 & 0.256 & 0.273 & 0.228 \\
\hline $\mathrm{CuO}$ & 079 & 084 & .057 & 0.084 & .082 & 0.087 & .072 & 0.080 & 0.074 & 0.082 & 0.085 & 0.075 & 0.082 & 0.081 & 0.086 & 0.069 & .084 & 0.074 & 0.080 & 0.073 \\
\hline $\mathrm{Fe}_{2} \mathrm{O}_{3}$ & 20.401 & 21.980 & 15.216 & 26.009 & 24.026 & 27.328 & 22.717 & 22.192 & 22.159 & 26.533 & 24.200 & 24.457 & 24.714 & 23.673 & 26.183 & 21.718 & 24.158 & 22.005 & 22.341 & 23.439 \\
\hline $\mathrm{K}_{2} \mathrm{O}$ & 912 & 499 & .067 & 1.025 & 1.297 & 0.760 & 1.706 & 1.488 & 1.566 & 0.908 & 1.134 & 1.424 & 1.199 & 1.343 & 0.893 & 1.863 & 1.137 & 1.584 & 1.467 & 1.584 \\
\hline $\mathrm{La}_{2} \mathrm{O}_{3}$ & 0.079 & 0.080 & 0.068 & 0.093 & 0.088 & 0.095 & 0.086 & 0.082 & 0.081 & 0.093 & 0.086 & 0.090 & 0.089 & 0.087 & 0.092 & 0.083 & 0.086 & 0.081 & 0.082 & 0.087 \\
\hline $\mathrm{MgO}$ & 353 & 0.334 & 0.410 & 1.942 & 1.424 & 2.099 & 1.830 & 0.876 & 1.251 & 2.147 & 1.156 & 2.145 & 1.610 & 1.336 & 1.761 & 1.654 & 1.148 & 1.220 & 0.919 & 1.966 \\
\hline $\mathrm{MnO}$ & 127 & 923 & 3.272 & 5.838 & 5.566 & 6.271 & 4.782 & 5.521 & 5.375 & 6.106 & 6.010 & 5.134 & 5.674 & 5.528 & 6.189 & 4.595 & 6.014 & 5.364 & 5.545 & 4.946 \\
\hline $\mathrm{Na}_{2} \mathrm{O}$ & 19.996 & 19.422 & 21.461 & 22.028 & 22.005 & 21.763 & 22.871 & 21.814 & 22.169 & 21.967 & 21.539 & 22.721 & 22.014 & 22.001 & 21.683 & 22.949 & 21.538 & 22.170 & 21.819 & 22.799 \\
\hline $\mathrm{NiO}$ & 5.866 & 7.773 & 1.249 & 3.715 & 4.365 & 4.337 & 1.456 & 5.598 & 4.262 & 3.785 & 6.065 & 1.509 & 4.133 & 4.476 & 4.957 & 1.427 & 6.081 & 4.298 & 5.536 & 1.480 \\
\hline $\mathrm{PbO}$ & 0.200 & 0.173 & 0.265 & 0.166 & 0.175 & 0.151 & 0.202 & 0.177 & 0.183 & 0.157 & 0.160 & 0.190 & 0.171 & 0.176 & 0.153 & 0.209 & 0.160 & 0.183 & 0.176 & 0.196 \\
\hline $\mathrm{SO}_{4}$ & 1.098 & 1.095 & 1.109 & 1.099 & 1.098 & 1.097 & 1.104 & 1.097 & 1.100 & 1.099 & 1.095 & 1.103 & 1.098 & 1.098 & 1.096 & 1.105 & 1.095 & 1.100 & 1.097 & 1.104 \\
\hline $\mathrm{SiO}_{2}$ & 2.407 & 2.044 & 3.373 & 2.732 & 2.607 & 2.615 & 3.204 & 2.385 & 2.681 & 2.751 & 2.285 & 3.187 & 2.659 & 2.591 & 2.504 & 3.220 & 2.286 & 2.679 & 2.400 & 3.205 \\
\hline $\mathrm{ThO}_{2}$ & 0.040 & 0.031 & 0.066 & 0.035 & 0.036 & 0.030 & 0.049 & 0.036 & 0.041 & 0.034 & 0.030 & 0.046 & 0.035 & 0.036 & 0.030 & 0.051 & 0.030 & 0.041 & 0.035 & 0.047 \\
\hline $\mathrm{TiO}_{2}$ & 0.013 & 0.010 & 0.021 & 0.021 & 0.018 & 0.021 & 0.025 & 0.015 & 0.019 & 0.022 & 0.015 & 0.026 & 0.020 & 0.018 & 0.019 & 0.025 & 0.015 & 0.019 & 0.015 & 0.026 \\
\hline $\mathrm{U}_{3} \mathrm{O}_{8}$ & 8.601 & 11.187 & 1.169 & 9.276 & 8.988 & 10.491 & 5.276 & 9.251 & 7.674 & 9.382 & 10.718 & 6.187 & 9.095 & 8.942 & 10.577 & 4.769 & 10.722 & 7.642 & 9.267 & 5.673 \\
\hline $\mathrm{ZnO}$ & 0.114 & 0.126 & 0.065 & 0.128 & 0.123 & 0.135 & 0.101 & 0.117 & 0.106 & 0.125 & 0.129 & 0.109 & 0.124 & 0.121 & 0.132 & 0.095 & 0.128 & 0.105 & 0.117 & 0.103 \\
\hline $\mathrm{ZrO}_{2}$ & 0.317 & 0.339 & 0.235 & 0.279 & 0.289 & 0.285 & 0.238 & 0.301 & 0.270 & 0.268 & 0.309 & 0.240 & 0.283 & 0.289 & 0.291 & 0.235 & 0.308 & 0.268 & 0.299 & 0.236 \\
\hline Total & 100.00 & 100.00 & 100.00 & 100.00 & 100.00 & 100.00 & 100.00 & 100.00 & 100.00 & 100.00 & 100.00 & 100.00 & 100.00 & 100.00 & 100.00 & 100.00 & 100.00 & 100.00 & 100.00 & 100.0 \\
\hline
\end{tabular}

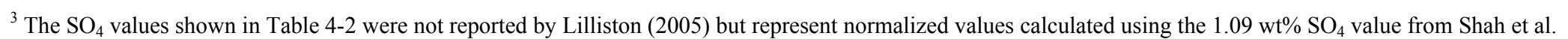
(2005).
} 


\subsection{Candidate Frit Compositions}

Based upon preliminary assessments of the SB4 compositions, six candidate frits were identified (see Table 5-3) for consideration with each of the normalized sludge oxide compositions of Table 5-2. The glass system formed by combining a frit candidate with a sludge option was explored at 36 different WLs, from 25 to $60 \%$ in increments of 1 . Thus for the 20 SB 4 options, six frit candidates, and 36 WLs, there were 4320 glass compositions generated.

A closer review of the frits listed in Table 5-3 indicates fixed concentrations of $\mathrm{B}_{2} \mathrm{O}_{3}$ and $\mathrm{Li}_{2} \mathrm{O}$ at $8 \mathrm{wt} \%$ with only the $\mathrm{Na}_{2} \mathrm{O}$ and $\mathrm{SiO}_{2}$ concentrations varying. In general, the frit compositions increase in $\mathrm{Na}_{2} \mathrm{O}$ by $1 \%$ and decrease respectively in $\mathrm{SiO}_{2}$ proceeding from Frit 418 (the most refractory frit being considered) to Frit 431. Throughout this report, this system will be referred to as a "sliding $\mathrm{Na}_{2} \mathrm{O}$ scale" concept which has been developed to accommodate potential $\mathrm{Na}_{2} \mathrm{O}$ concentration differences in the sludge as a result of varying blending and/or washing strategies being considered. ${ }^{4}$ More specifically, frit development and selection would like to take advantage of the "cornerstone" DWPF frits (Frit 320 and Frit 418) that were developed to improve WL and/or melt rate for SB2 and SB3, respectively. A primary difference between SB2 and SB3 was the washing endpoint which resulted in a dramatic difference in $\mathrm{Na}_{2} \mathrm{O}$ concentrations (i.e., SB2 was considered to be an "overwashed" sludge having a much lower $\mathrm{Na}_{2} \mathrm{O}$ content than $\mathrm{SB} 3$ which was considered to be "underwashed"). Frit development efforts accommodated this shift in $\mathrm{Na}_{2} \mathrm{O}$ content between SB2 and SB3 by a reduction in $\mathrm{Na}_{2} \mathrm{O}$ content in the frit - transitioning from Frit 320 (with $12 \% \mathrm{Na}_{2} \mathrm{O}$ ) to Frit 418 (with $8 \% \mathrm{Na}_{2} \mathrm{O}$ ). This shift or "sliding $\mathrm{Na}_{2} \mathrm{O}$ scale" concept has proven effective for DWPF as waste throughputs for SB3 with Frit 418 have been at their highest since radioactive operations began. If possible, frit development efforts for SB4 would like to continue the use of this concept given DWPF has process history with the cornerstone frits and their use (or slight modifications to their compositions) would hopefully minimize the risk or "unknowns" of using a frit with drastically different ratios and/or new oxides. If the projected operating windows do not meet expectations (i.e., in terms of upper WL or range of WLs) with the frits listed in Table 5-3, alternative frit compositions will be developed. However, if the "sliding $\mathrm{Na}_{2} \mathrm{O}$ scale" approach is successful for SB4, ${ }^{5}$ consideration of these frits may have their advantages (if only based on lower perceived risks).

Table 4-3. Identification and Composition of Candidate Frits (wt\%)

\begin{tabular}{||c|c|c|c|c||}
\hline \hline Frit ID & $\mathbf{B}_{2} \mathbf{O}_{3}$ & $\mathbf{L i}_{\mathbf{2}} \mathbf{O}$ & $\mathbf{N a}_{\mathbf{2}} \mathbf{O}$ & $\mathbf{S i O}_{2}$ \\
\hline 418 & 8 & 8 & 8 & 76 \\
\hline 426 & 8 & 8 & 9 & 75 \\
\hline 425 & 8 & 8 & 10 & 74 \\
\hline 417 & 8 & 8 & 11 & 73 \\
\hline 320 & 8 & 8 & 12 & 72 \\
\hline 431 & 8 & 8 & 13 & 71 \\
\hline
\end{tabular}

\footnotetext{
${ }^{4}$ The 20 SB4 options outlined by Lilliston (2005) are based on various blending strategies represented by various percentages of the tank volumes/masses. The projected nominal composition do not specifically address the possibly of different washing options that could be performed in the tank farm. In this report, gross assumptions are made regarding the washing impacts and are used to assess this impact on the frit selection process (see Section 5.6).

5 "Success" being defined based on the ability of this concept to effectively compensate for the various blending and/or washing strategies developed by the CBU to produce operating windows (in terms of model predictions) meeting DWPF expectations.

${ }^{6}$ Frit 441 , which contains $15 \% \mathrm{Na}_{2} \mathrm{O}\left(69 \% \mathrm{SiO}_{2}\right)$, is not shown in Table 4-3 but will be utilized in some of the MAR assessments to demonstrate the continual concept of the "sliding $\mathrm{Na}_{2} \mathrm{O}$ scale". The projected operating windows for Frit 441 are not summarized but details can be found in Appendix A which are discussed in the text for some blending options.
} 


\subsection{PROJECTED OPERATING WINDOWS FOR THE SB4 BLENDING OPTIONS}

Each of the 4320 glass compositions was assessed against the MAR criteria of PCCS. Table A1 in the Appendix provides a summary of the outcomes from this investigation by providing the MAR results for each sludge option/frit candidate combination. For each sludge / frit system, these results are indicated relative to WL. That is, the "Min WL" and "Max WL" columns represent the minimum and maximum WLs, respectively, which met all MAR criteria thus establishing the projected operating window. The "limited below by" and "limited above by" columns indicates the property (or properties) that limit access to lower or higher WLs, respectively. The next six columns represent the predicted durability, viscosity, and $\mathrm{T}_{\mathrm{L}}$ at the minimum and maximum WL, respectively. As previously mentioned, although a nominal $\mathrm{SO}_{4}$ concentration of $1.09 \mathrm{wt} \%$ was added to each of the 20 pre-normalized compositions, an assumed $\mathrm{SO}_{4}$ limit was not activated, therefore, no $\mathrm{SO}_{4}$ restrictions are imposed on the projected operating windows.

Numerous comparisons can be made among the 20 SB4 blending scenarios. The authors have elected to highlight some of the more interesting comparisons within each primary classification (i.e., SB4-only, 1100 canister, and 1200 canister options). ${ }^{7}$ Comparisons among these primary classifications will be made as warranted.

\subsection{SB4-Only}

Table 5-1 provides a summary of the results for model-based MAR assessments for the SB4 Only options (Baseline, Max Al, and Min Al) with each candidate frit. Also shown in Table 5-1 is the wt $\% \mathrm{Na}_{2} \mathrm{O}$ for each frit. The projected operating windows in terms of upper and lower WLs that satisfy the MAR constraints for the specific sludge / frit blend as well as the property that limits access to higher WLs are also provided. ${ }^{8}$ For example, consider the Frit 418 - SB4 Only Baseline case. The projected operating window is $33-36 \%$ WL with predictions of high viscosity $(\eta)$ and liquidus temperature $\left(\mathrm{T}_{\mathrm{L}}\right)$ limiting access to WLs of $<33 \%$ and $>37 \%$, respectively. As the $\mathrm{Na}_{2} \mathrm{O}$ concentration in the frit gradually increases (transitioning from Frit 426 to Frit 320), the higher alkali content gradually reduces predictions of viscosity and $\mathrm{T}_{\mathrm{L}}$ which have a positive impact on the operating window size. For example, Frit 320 (with $12 \% \mathrm{Na}_{2} \mathrm{O}$ ) results in an operating window from $25-40 \% \mathrm{WL}$ with predictions of $\mathrm{T}_{\mathrm{L}}$ limiting access to higher WLs. Transitioning from Frit 320 (with $12 \% \mathrm{Na}_{2} \mathrm{O}$ ) to Frit 431 (with $13 \% \mathrm{Na}_{2} \mathrm{O}$ ) indicates no advantage in terms of the projected operating window - perhaps an advantage in terms of melt rate given the higher alkali content. Given the gradual trend of increasing upper WLs with increasing $\mathrm{Na}_{2} \mathrm{O}$ concentrations in the frit, the obvious question to ask is what happens if frit composition with $>13 \% \mathrm{Na}_{2} \mathrm{O}$ are used - in terms of the projected operating window. Although not shown in Table Table 5-1, Frit 441, with $15 \% \mathrm{Na}_{2} \mathrm{O}$, was coupled with the SB4-only Baseline option and the result was an operating window from $30-42 \% \mathrm{WL}$ (see Table A1). Predictions of durability restrict access to WLs $<30 \%$ while $\mathrm{T}_{\mathrm{L}}$ limits access to WLs $>42 \%$. Although there are potential advantages with Frit $441(42 \%$ upper WL), the disadvantage may be the loss of robustness to compositional variation.

\footnotetext{
${ }^{7}$ Lilliston (2005) uses the SB4-only, 1100 canister and 1200 canister options to denote the various volumes or mass of the SB3 heel to be blended with SB4. The SB4-only case assumes no SB3 heel is blended. The 1100 and 1200 canister options refer to the volume or mass of SB3 remaining after 1100 and 1200 canisters have been produced.

${ }^{8}$ Liquidus temperature is denoted by $T_{L}$ and high viscosity by high $\eta$. In addition, for two of the Frit 418 - SB4-Only Baseline cases, high $\eta$ also restricts access to lower WLs.
} 
The last column of Table 5-1 provides the frit and maximum WL as determined by Lilliston (2005) using the limits for durability currently in DWPF's PCCS and a $20^{\circ} \mathrm{C}$ "offset" for the $\mathrm{T}_{\mathrm{L}}$ MAR. ${ }^{9}$ For the assessments of this paper study, the new, proposed durability limits (Edwards et al., 2003) and the "true" $\mathrm{T}_{\mathrm{L}}$ MAR were used. Use of the new durability limits allows for consideration of frits with higher alkali content for a given sludge composition which provides access to compositional regions which have been shown to improve melt rate and/or waste loading - both critical factors in defining waste throughput for DWPF. More will be said regarding the potential impact on the frit selection process based on the use of the current versus proposed durability limits. For now it suffices to say that Lilliston identified the use of Frit 431 as a leading candidate for all three SB4-only options. The results of the MAR-based assessments agree quite well.

Table 5-1. SB4 Only Options - MAR Results

\begin{tabular}{||c|c|c|c|c|c|c|c||}
\hline \hline & Frit 418 & Frit 426 & Frit 425 & Frit 417 & Frit 320 & Frit 431 & $\begin{array}{c}\text { Lilliston } \\
(2005)\end{array}$ \\
\hline $\begin{array}{c}\% \mathrm{Na}_{2} \mathrm{O} \\
\text { (in frit) }\end{array}$ & 8 & 9 & 10 & 11 & 12 & 13 & \\
\hline Baseline & $\begin{array}{c}(\text { high } \eta) \\
33-36 \\
\left(\mathrm{~T}_{\mathrm{L}}\right)\end{array}$ & $\begin{array}{c}25-37 \\
\left(\mathrm{~T}_{\mathrm{L}}\right)\end{array}$ & $\begin{array}{c}25-38 \\
\left(\mathrm{~T}_{\mathrm{L}}\right)\end{array}$ & $\begin{array}{c}25-39 \\
\left(\mathrm{~T}_{\mathrm{L}}\right)\end{array}$ & $\begin{array}{c}25-40 \\
\left(\mathrm{~T}_{\mathrm{L}}\right)\end{array}$ & $\begin{array}{c}25-40 \\
\left(\mathrm{~T}_{\mathrm{L}}\right)\end{array}$ & $\begin{array}{c}\text { Frit 431, } \\
39.4 \%\end{array}$ \\
\hline Max Al & - & - & - & - & $25-60$ & $25-60$ & $\begin{array}{c}\text { Frit 431, } \\
61.3 \%\end{array}$ \\
\hline Min Al & $\begin{array}{c}(\text { high } \eta) \\
27-32 \\
\left(\mathrm{~T}_{\mathrm{L}}\right)\end{array}$ & $\begin{array}{c}25-33 \\
\left(\mathrm{~T}_{\mathrm{L}}\right)\end{array}$ & $\begin{array}{c}25-34 \\
\left(\mathrm{~T}_{\mathrm{L}}\right)\end{array}$ & $\begin{array}{c}25-35 \\
\left(\mathrm{~T}_{\mathrm{L}}\right)\end{array}$ & $\begin{array}{c}25-35 \\
\left(\mathrm{~T}_{\mathrm{L}}\right)\end{array}$ & $\begin{array}{c}25-36 \\
\left(\mathrm{~T}_{\mathrm{L}}\right)\end{array}$ & $\begin{array}{c}\text { Frit 431, } \\
35.5 \%\end{array}$ \\
\hline
\end{tabular}

The "Max Al" option is extremely interesting. Model based predictions restrict the use of Frits 418, 426, 425 , and 417 - predictions of high viscosity result in no operating windows over the entire $25-60 \% \mathrm{WL}$ interval. However, a $1 \%$ shift in the $\mathrm{Na}_{2} \mathrm{O}$ content of the frit transitions from a system with no operating window (with Frit 417) to one that is not restricted over the entire $25-60 \%$ WL interval (with Frit 320). This demonstrates the sensitivity of the PCCS model interactions to slight changes in frit composition and the need to consider robustness to compositional variation during the frit selection process.

The "red" shading in Table 5-1 indicates that the SB4-only "Min Al" case is somewhat troubling from the paper study perspective, since it has consistently smaller windows as compared to the other options. Use of the term "troublesome" is subjective but it reflects the inability of the existing frits to obtain upper WLs of at least $40 \%$. For the "Min Al" case, the maximum upper WL obtained is $36 \%$ with the use of Frit 431 (the highest $\mathrm{Na}_{2} \mathrm{O}$ containing frit at 13\%). As with the SB4-Only baseline case, the use of higher alkali containing frits (Frit 441 with $15 \% \mathrm{Na}_{2} \mathrm{O}$ ) may be beneficial in terms of broadening the projected operating window. However, use of Frit 441 with the "Min Al" case results in almost complete elimination of the window as predictions of durability and low viscosity restrict the operating window to $36-38 \%$ WL (refer to Table A1). It should be noted that the "Min Al" case (as it is being referred to) also has the minimum $\mathrm{Na}_{2} \mathrm{O}$ concentration for the three SB4-only options (see Table 5-1). Therefore, the use of higher alkali frits to balance the $\mathrm{Na}_{2} \mathrm{O}$-deficient sludge was expected to be less effective. ${ }^{10}$

\footnotetext{
${ }^{9}$ Yellow shading is used to highlight the "candidate" frit that was identified by Lilliston (2005) during his assessment of the various SB4 options.

${ }^{10}$ Although not a primary focus of this report, previous assessments of preliminary SB4 compositional projections have provided insight into the impact of the $\mathrm{Na}_{2} \mathrm{O}$ concentration in the sludge versus that in the frit on the ability of frit development effort to compensate or retain similar projected operating windows. Preliminary assessments of SB4 compositions (referred to as Set \#2 in WSRC-NB-200400134 with much lower $\mathrm{Na}_{2} \mathrm{O}$ concentrations for all 20 options) indicate that the ability of the " $\mathrm{Na}_{2} \mathrm{O}$ sliding scale" concept to account for or balance the alkali content was less effective when the $\mathrm{Na}_{2} \mathrm{O}$ concentration in the sludge was less than that in the frit. If $\mathrm{Na}_{2} \mathrm{O}$
} 


\subsection{Canister Options}

Table 5-2 provides a summary of the MAR results for the 1100 Canister Options. ${ }^{11}$ The shading of the table provides some general insight into the frit selection process as well as the impact of the current versus proposed durability limits. Yellow shading is used to highlight the frit that was identified by Lilliston (2005) during his assessment of the various SB4 options. Green is used to highlight the frit that provides the "maximum" upper WL (with a relatively large window). Blue is used to highlight a frit / sludge combination with a relatively large operating window (albeit subjective) and that has a relatively high alkali content, which may help improve melt rate. If there is no "blue" cell in a row, then the "green" cell is considered to meet this criterion.

Table 5-2. 1100 Canister Options - MAR Results

\begin{tabular}{|c|c|c|c|c|c|c|c|}
\hline & Frit 418 & Frit 426 & Frit 425 & Frit 417 & Frit 320 & Frit 431 & $\begin{array}{c}\text { Lilliston } \\
\text { (2005) }\end{array}$ \\
\hline $\begin{array}{l}\% \mathrm{Na}_{2} \mathrm{O} \\
\text { (in frit) }\end{array}$ & 8 & 9 & 10 & 11 & 12 & 13 & \\
\hline Baseline & $\begin{array}{c}25-42 \\
\left(\mathrm{~T}_{\mathrm{L}}\right)\end{array}$ & $\begin{array}{c}25-43 \\
\left(T_{L}\right)\end{array}$ & $\begin{array}{c}25-44 \\
\left(\mathrm{~T}_{\mathrm{L}}\right)\end{array}$ & $\begin{array}{c}25-45 \\
\left(T_{L}\right)\end{array}$ & $\begin{array}{l}25-44 \\
\text { (low } \eta)\end{array}$ & $\begin{array}{c}\left(\Delta \mathrm{G}_{\mathrm{P}}\right) \\
27-41 \\
(\text { low } \eta)\end{array}$ & $\begin{array}{c}\text { Frit } 418, \\
40.5 \%\end{array}$ \\
\hline $\begin{array}{c}2^{\text {nd }} \\
\text { transfer } \\
\text { baseline }\end{array}$ & $\begin{array}{c}25-40 \\
\left(\mathrm{~T}_{\mathrm{L}}\right)\end{array}$ & $\begin{array}{c}25-41 \\
\left(T_{L}\right)\end{array}$ & $\begin{array}{c}25-42 \\
\left(\mathrm{~T}_{\mathrm{L}}\right)\end{array}$ & $\begin{array}{c}25-43 \\
\left(\mathrm{~T}_{\mathrm{L}}\right)\end{array}$ & $\begin{array}{c}25-44 \\
\left(T_{L}\right)\end{array}$ & $\begin{array}{l}25-43 \\
(\text { low } \eta)\end{array}$ & $\begin{array}{c}\text { Frit } 418, \\
39.3 \%\end{array}$ \\
\hline Min Al & $\begin{array}{c}25-40 \\
\left(T_{L}\right)\end{array}$ & $\begin{array}{c}25-41 \\
\left(\mathrm{~T}_{\mathrm{L}}\right)\end{array}$ & $\begin{array}{c}25-42 \\
\left(\mathrm{~T}_{\mathrm{L}}\right)\end{array}$ & $\begin{array}{c}25-43 \\
\left(T_{L}\right)\end{array}$ & $\begin{array}{l}25-41 \\
(\text { low } \eta)\end{array}$ & - & $\begin{array}{c}\text { Frit } 418, \\
38.9 \%\end{array}$ \\
\hline Max Al & $\begin{array}{c}\text { (high } \eta \text { ) } \\
27-51 \\
\left(T_{L}\right)\end{array}$ & $\begin{array}{c}25-52 \\
\left(T_{L}\right)\end{array}$ & $\begin{array}{c}25-53 \\
\left(\mathrm{~T}_{\mathrm{L}}\right)\end{array}$ & $\begin{array}{c}25-54 \\
\left(T_{L}\right)\end{array}$ & $\begin{array}{l}25-53 \\
(\text { low } \eta)\end{array}$ & $\begin{array}{l}25-50 \\
(\text { low } \eta)\end{array}$ & $\begin{array}{c}\text { Frit } 418, \\
49.4 \%\end{array}$ \\
\hline Min $\mathrm{Ce}$ & $\begin{array}{c}25-38 \\
\left(\mathrm{~T}_{\mathrm{L}}\right) \\
\end{array}$ & $\begin{array}{c}25-39 \\
\left(\mathrm{~T}_{\mathrm{L}}\right) \\
\end{array}$ & $\begin{array}{c}25-40 \\
\left(\mathrm{~T}_{\mathrm{L}}\right) \\
\end{array}$ & $\begin{array}{c}25-41 \\
\left(\mathrm{~T}_{\mathrm{L}}\right) \\
\end{array}$ & $\begin{array}{c}25-41 \\
\left(\mathrm{~T}_{\mathrm{L}}\right) \\
\end{array}$ & $\begin{array}{c}25-42 \\
\left(\mathrm{~T}_{\mathrm{L}}\right)\end{array}$ & $\begin{array}{c}\text { Frit } 418, \\
36.8 \% \\
\end{array}$ \\
\hline Min Fe & $\begin{array}{c}\text { (high } \eta \text { ) } \\
26-41 \\
\left(T_{L}\right)\end{array}$ & $\begin{array}{c}25-42 \\
\left(\mathrm{~T}_{\mathrm{L}}\right)\end{array}$ & $\begin{array}{c}25-43 \\
\left(\mathrm{~T}_{\mathrm{L}}\right)\end{array}$ & $\begin{array}{c}25-44 \\
\left(\mathrm{~T}_{\mathrm{L}}\right)\end{array}$ & $\begin{array}{c}25-45 \\
\left(T_{L}\right)\end{array}$ & $\begin{array}{c}25-46 \\
\left(T_{L}\right)\end{array}$ & $\begin{array}{c}\text { Frit } 418, \\
40.0 \%\end{array}$ \\
\hline Max Mg & $\begin{array}{c}25-41 \\
\left(\mathrm{~T}_{\mathrm{L}}\right)\end{array}$ & $\begin{array}{c}25-42 \\
\left(\mathrm{~T}_{\mathrm{L}}\right)\end{array}$ & $\begin{array}{c}25-43 \\
\left(\mathrm{~T}_{\mathrm{L}}\right)\end{array}$ & $\begin{array}{c}25-44 \\
\left(T_{L}\right)\end{array}$ & $\begin{array}{l}25-43 \\
(\text { low } \eta)\end{array}$ & $\begin{array}{c}\left(\Delta \mathrm{G}_{\mathrm{P}}\right) \\
32-40 \\
(\text { low } \eta)\end{array}$ & $\begin{array}{c}\text { Frit } 418, \\
40.2 \%\end{array}$ \\
\hline Max Ni & $\begin{array}{c}25-36 \\
\left(\mathrm{~T}_{\mathrm{L}}\right)\end{array}$ & $\begin{array}{c}25-37 \\
\left(\mathrm{~T}_{\mathrm{L}}\right)\end{array}$ & $\begin{array}{c}25-38 \\
\left(\mathrm{~T}_{\mathrm{L}}\right) \\
\end{array}$ & $\begin{array}{c}25-39 \\
\left(\mathrm{~T}_{\mathrm{L}}\right)\end{array}$ & $\begin{array}{c}25-40 \\
\left(\mathrm{~T}_{\mathrm{L}}\right)\end{array}$ & $\begin{array}{c}25-41 \\
\left(\mathrm{~T}_{\mathrm{L}} / \text { low } \eta\right)\end{array}$ & $\begin{array}{c}\text { Frit } 418, \\
35.5 \% \\
\end{array}$ \\
\hline Max Ti & $\begin{array}{c}25-50 \\
\left(\mathrm{~T}_{\mathrm{L}}\right)\end{array}$ & $\begin{array}{c}25-51 \\
\left(\mathrm{~T}_{\mathrm{L}}\right)\end{array}$ & $\begin{array}{c}25-52 \\
\left(\mathrm{~T}_{\mathrm{L}}\right)\end{array}$ & $\begin{array}{l}25-52 \\
\text { (low } \eta)\end{array}$ & $\begin{array}{l}25-49 \\
\text { (low } \eta)\end{array}$ & $\begin{array}{l}25-46 \\
(\text { low } \eta)\end{array}$ & $\begin{array}{c}\text { Frit } 418, \\
48.0 \%\end{array}$ \\
\hline
\end{tabular}

concentration in the sludge is greater than that in the frit, then as WL increases, the $\mathrm{Na}_{2} \mathrm{O}$ content in the glass increases which (in general) should reduce $\mathrm{T}_{\mathrm{L}}$ and provide access to higher WLs for $\mathrm{T}_{\mathrm{L}}$ limited systems. If the $\mathrm{Na}_{2} \mathrm{O}$ content in the sludge is less than that in the frit, as WL increases the glass (in general) becomes more refractory, and predictions of $\mathrm{T}_{\mathrm{L}}$ and/or high viscosity not only restrict access to higher WLs but begin to collapse the projected operating window altogether.

${ }^{11}$ See Table A1 for more details associated with these systems. In addition, Table A1 includes the use of Frit $441\left(15 \% \mathrm{Na}_{2} \mathrm{O}\right)$ with all SB4 options which are not summarized in Table 5-2. 
The first general observation is the difference between Frit 418, the frit that Lilliston (2005) identified as the primary frit for each of the 1100 canister options (see "yellow" cells and last column), and the "green" or "blue" shaded cells which represent systems based on higher alkali frits which increased the projected operating window size and/or have the potential to improve melt rate. This difference is solely based on the durability limits utilized. Lilliston (2005) used the current (more conservative) limits while this assessment used those limits proposed by Edwards et al. (2003). As previously mentioned, the proposed limits allow the use of higher alkali frits (for a given sludge composition) which have been shown to improve melt rate and/or waste loading. As an example, consider the 1100 Canister Baseline option. Lilliston (2005) suggested the use of Frit 418 while this assessment allows either the use of Frit 417 or Frit 320 (both higher alkali frits) which may improve melt rate and/or waste throughput. Assuming the historical trend between melt rate and total alkali content holds for the SB4 system, selection of a "primary" frit candidate may depend on the sludge option being considered. That is, one may elect to use Frit 320 for the 1100 Canister Baseline option, but Frit 431 for the 1100 Canister, $2^{\text {nd }}$ Transfer Baseline option. The challenge for the frit selection process will be to assess the robustness of a candidate frit to anticipated compositional changes and then use experimental melt rate data to select an optimal frit that is robust and yields high waste throughputs.

In general, the results for the 1100 canister options suggest that typical operating windows cover WLs from 25 to the mid-40\%'s or low-50\%'s. For most of the sludge options (all but 2 - "Min Ce" and "Min Fe"), as higher alkali frits are used, the resulting glass systems transition from being $\mathrm{T}_{\mathrm{L}}$ limited at the maximum WL to being low $\eta$ limited systems. This trend was expected as higher alkali systems typically result in lower $T_{L}$ and lower viscosity predictions with the anticipated result being a reduction in $T_{L}$ which gradually allows higher WLs to be obtained up to the point where predictions of low viscosity become limiting. It is interesting to note that both $\mathrm{T}_{\mathrm{L}}$ and low viscosity limit access to higher WLs in the Frit 431 - "Max Ni" option which may be indicative of an "optimized" system for that specific blending option. In general terms, the use of the "sliding $\mathrm{Na}_{2} \mathrm{O}$ scale" concept does allow one to compensate or balance the $\mathrm{Na}_{2} \mathrm{O}$ through frit selection to maximize the projected operating windows. The desire to push the frit $\mathrm{Na}_{2} \mathrm{O}$ concentrations to their highest must be balanced with the $\mathrm{Na}_{2} \mathrm{O}$ content in the sludge. This compensation is realized in the fact that some maximum operating windows are obtained with an "intermediate" $\mathrm{Na}_{2} \mathrm{O}$-based frit (e.g., the Frit 417 - 1100 Can Baseline option).

Another general observation is the fact that most of the candidate frits appear to provide some measure of robustness with respect to the various sludge blending options. More specifically, consider the cornerstone frits (Frit 418 and Frit 320). These two frits provide operating windows (perhaps not optimal) for all nine SB4 1100 Canister options being considered based on model predictions. The identification of a primary frit for a specific sludge option will ultimately be based not only on the operating window size but also robustness and melt rate - two inputs not addressed in this study.

In addition to the general comparisons noted above, there are a few specific systems that should be mentioned.

$>$ Based on the model predictions, it appears that a frit change would not be required between the SB4 1100 canister baseline and the $2^{\text {nd }}$ transfer baseline. For example, Frit 320 provides identical projected operating windows for both sludge options.

$>$ The "Min Al" case demonstrates the "collapse" of the "sliding $\mathrm{Na}_{2} \mathrm{O}$ scale" concept as one transitions from a $25-41 \%$ WL interval with Frit 320 to the complete elimination of the operating window with a $1 \%$ increase in $\mathrm{Na}_{2} \mathrm{O}$ content in the frit. The difference is that Frit 431 has $1 \mathrm{wt} \%$ higher $\mathrm{Na}_{2} \mathrm{O}$ (and $1 \mathrm{wt} \%$ lower $\mathrm{SiO}_{2}$ ) than Frit 320, which demonstrates the sensitivity of the PCCS model interactions to slight changes in frit composition and the need to consider robustness to compositional variation during the frit selection process. 
$>$ The "Max Al" and "Max Ti" sludge options provide operating windows from $25 \%$ WL to the low-to-mid 50\%'s. These options may be attractive from a paper study perspective but issues associated with melt rate need to be addressed prior to further exploring these blending options or scenarios. More specifically, the high $\mathrm{Al}_{2} \mathrm{O}_{3}$ content of the "Max $\mathrm{Al}$ " could impede melt rate which may make that blending strategy less attractive.

$>$ In terms of a "troublesome" sludge option, there do not appear to be any 1100 Canister blending options that meet this subjective criterion (i.e., maximum upper $\mathrm{WL}$ of $\leq 40 \%$ for all frits).

\subsection{Canister Options}

Table 5-3 provides a summary of the MAR results for the 1200 Canister Options. ${ }^{12}$ The shading of the table follows the pattern used in Table 5-2. As with the 1100 canister options, the use of the proposed durability limits allows higher alkali frits to be investigated relative to the use of the current limits. This is demonstrated by Lilliston's (2005) identifying Frit 418 as a "leading" candidate (yellow shaded cells) for all eight 1200 canister options with the current durability limits while this assessment against the proposed limits allows the use higher alkali frits for each sludge option. Based on model predictions, use of the higher alkali frits does allow higher WLs to be obtained for all 1200 canister options. A second potential advantage may be an improved melt rate given historical trends between melt rate and total alkali in the frit.

In general, the results for the 1200 canister options suggest that typical operating windows cover WLs from 25 to the mid-40\%'s or low-50\%'s. For most of the sludge options (all but 2 - "Min Ce" and "Min $\mathrm{Mg}$ "), as higher alkali frits are used, the resulting glass systems transition from being $\mathrm{T}_{\mathrm{L}}$ limited at the maximum WL to being low $\eta$ limited. Again, this trend was anticipated with the use of the "sliding $\mathrm{Na}_{2} \mathrm{O}$ scale" concept. As in previous assessments, as one transitions toward the more alkali-rich frits, the gradual reduction in $\mathrm{T}_{\mathrm{L}}$ allows higher WLs to be accessed until predictions of low viscosity become the limiting property.

As with the 1100 canister options, the cornerstone frits (Frit 418 and Frit 320) also show robustness as their use does result in projected operating windows (perhaps not optimal) for all eight options being considered. The challenge for the frit selection process will be to assess the robustness of a candidate frit to anticipated compositional changes and then use experimental melt rate data to select an optimal system that is robust and yields high throughputs.

In addition to the general comparisons noted above, there are a few specific systems in the 1200 canister options that should be mentioned or discussed.

$>$ Based on the model predictions, it appears that a frit change would not be required between the SB4 1200 canister baseline and the $2^{\text {nd }}$ transfer baseline.

$>$ The "Min Al" case demonstrates the "collapse" of the "sliding $\mathrm{Na}_{2} \mathrm{O}$ scale" concept as one transitions from a $25-42 \%$ WL interval with Frit 320 to almost complete elimination of the operating window $(35-39 \% \mathrm{WL})$ with a $1 \%$ increase in $\mathrm{Na}_{2} \mathrm{O}$ content in the frit (Frit 431). Again, this highlights the sensitivity of the PCCS model interactions to slight changes in frit composition and the need to consider robustness to compositional variation during the frit selection process.

$>$ The "Max Al" and "Max Mg" sludge options provide operating windows from $25 \% \mathrm{WL}$ to the low-to-mid 50\%'s. These options may be attractive from a paper study perspective, but

\footnotetext{
${ }^{12}$ See Table A1 for more details associated with these systems. In addition, Table A1 includes the use of Frit $441\left(15 \% \mathrm{Na}_{2} \mathrm{O}\right) \mathrm{with}$ all SB4 options which are not summarized in Table 5-3.
} 
issues associated with melt rate need to be addressed prior to these blending options or scenarios being explored further. More specifically, the high $\mathrm{Al}_{2} \mathrm{O}_{3}$ content of the "Max Al" could impede melt rate which may make that blending strategy less attractive.

$>$ In terms of a "troublesome" sludge option, there does not appear to be any 1200 Canister blending option that meets this subjective criterion (i.e., maximum upper WL of $\leq 40 \%$ for all frits). That is, a frit can be selected for each option to provide a relatively large operating window that has an upper WLs that exceeds the $40 \%$ mark.

Table 5-3. 1200 Canister Options - MAR Results

\begin{tabular}{|c|c|c|c|c|c|c|c|}
\hline & Frit 418 & Frit 426 & Frit 425 & Frit 417 & Frit 320 & Frit 431 & $\begin{array}{c}\text { Lilliston } \\
(2005)\end{array}$ \\
\hline $\begin{array}{l}\% \mathrm{Na}_{2} \mathrm{O} \\
\text { (in frit) } \\
\end{array}$ & 8 & 9 & 10 & 11 & 12 & 13 & \\
\hline Baseline & $\begin{array}{c}25-41 \\
\left(T_{L}\right)\end{array}$ & $\begin{array}{c}25-42 \\
\left(T_{L}\right)\end{array}$ & $\begin{array}{c}25-43 \\
\left(T_{L}\right)\end{array}$ & $\begin{array}{c}25-44 \\
\left(T_{L}\right)\end{array}$ & $\begin{array}{c}25-45 \\
\left(T_{L} / \text { low } \eta\right)\end{array}$ & $\begin{array}{l}25-42 \\
(\text { low } \eta)\end{array}$ & $\begin{array}{c}\text { Frit 418, } \\
39.7 \%\end{array}$ \\
\hline $\begin{array}{c}2^{\text {nd }} \\
\text { transfer } \\
\text { baseline }\end{array}$ & $\begin{array}{c}25-40 \\
\left(T_{L}\right)\end{array}$ & $\begin{array}{c}25-41 \\
\left(\mathrm{~T}_{\mathrm{L}}\right)\end{array}$ & $\begin{array}{c}25-42 \\
\left(T_{L}\right)\end{array}$ & $\begin{array}{c}25-43 \\
\left(\mathrm{~T}_{\mathrm{L}}\right)\end{array}$ & $\begin{array}{c}25-44 \\
\left(T_{L}\right)\end{array}$ & $\begin{array}{l}25-44 \\
(\text { low } \eta)\end{array}$ & $\begin{array}{c}\text { Frit } 418, \\
39.1 \%\end{array}$ \\
\hline Min Al & $\begin{array}{c}25-39 \\
\left(T_{L}\right)\end{array}$ & $\begin{array}{c}25-40 \\
\left(\mathrm{~T}_{\mathrm{L}}\right)\end{array}$ & $\begin{array}{c}25-40 \\
\left(T_{L}\right)\end{array}$ & $\begin{array}{c}25-41 \\
\left(\mathrm{~T}_{\mathrm{L}}\right)\end{array}$ & $\begin{array}{c}25-42 \\
\left(T_{L} / \text { low } \eta\right)\end{array}$ & $\begin{array}{c}\left(\Delta \mathrm{G}_{\mathrm{P}}\right) \\
35-39 \\
(\text { low } \eta)\end{array}$ & $\begin{array}{c}\text { Frit } 418, \\
37.6 \%\end{array}$ \\
\hline $\operatorname{Max} \mathrm{Al}$ & $\begin{array}{c}\text { (high } \eta) \\
29-53 \\
\left(T_{L}\right)\end{array}$ & $\begin{array}{c}25-54 \\
\left(T_{L}\right)\end{array}$ & $\begin{array}{c}25-54 \\
\left(T_{L}\right)\end{array}$ & $\begin{array}{c}25-55 \\
\left(T_{L}\right)\end{array}$ & $\begin{array}{c}25-56 \\
\left(T_{L} / \text { low } \eta\right)\end{array}$ & $\begin{array}{l}25-53 \\
(\text { low } \eta)\end{array}$ & $\begin{array}{c}\text { Frit } 418, \\
50.3 \%\end{array}$ \\
\hline Max Ni & $\begin{array}{c}25-36 \\
\left(T_{L}\right)\end{array}$ & $\begin{array}{c}25-37 \\
\left(T_{L}\right)\end{array}$ & $\begin{array}{c}25-38 \\
\left(T_{L}\right)\end{array}$ & $\begin{array}{c}25-39 \\
\left(\mathrm{~T}_{\mathrm{L}}\right)\end{array}$ & $\begin{array}{c}25-40 \\
\left(T_{L}\right)\end{array}$ & $\begin{array}{c}25-41 \\
\left(T_{L} / \text { low } \eta\right)\end{array}$ & $\begin{array}{c}\text { Frit } 418, \\
35.4 \%\end{array}$ \\
\hline Min $\mathrm{Ce}$ & $\begin{array}{c}\text { high } \eta) \\
26-41 \\
\left(T_{L}\right)\end{array}$ & $\begin{array}{c}25-42 \\
\left(\mathrm{~T}_{\mathrm{L}}\right)\end{array}$ & $\begin{array}{c}25-43 \\
\left(T_{L}\right)\end{array}$ & $\begin{array}{c}25-44 \\
\left(T_{L}\right)\end{array}$ & $\begin{array}{c}25-45 \\
\left(T_{L}\right)\end{array}$ & $\begin{array}{c}25-46 \\
\left(T_{L}\right)\end{array}$ & $\begin{array}{c}\text { Frit } 418, \\
40.0 \%\end{array}$ \\
\hline Min Mg & $\begin{array}{c}25-38 \\
\left(\mathrm{~T}_{\mathrm{L}}\right)\end{array}$ & $\begin{array}{c}25-39 \\
\left(\mathrm{~T}_{\mathrm{L}}\right) \\
\end{array}$ & $\begin{array}{c}25-40 \\
\left(T_{L}\right)\end{array}$ & $\begin{array}{c}25-41 \\
\left(T_{L}\right)\end{array}$ & $\begin{array}{c}25-42 \\
\left(T_{L}\right)\end{array}$ & $\begin{array}{c}25-42 \\
\left(T_{L}\right)\end{array}$ & $\begin{array}{c}\text { Frit } 418, \\
36.9 \% \\
\end{array}$ \\
\hline Max Mg & $\begin{array}{c}\text { (high } \eta) \\
26-51 \\
\left(T_{L}\right)\end{array}$ & $\begin{array}{c}25-52 \\
\left(\mathrm{~T}_{\mathrm{L}}\right)\end{array}$ & $\begin{array}{c}25-53 \\
\left(T_{L}\right)\end{array}$ & $\begin{array}{c}25-54 \\
\left(T_{L} / \text { low } \eta\right)\end{array}$ & $\begin{array}{l}25-51 \\
(\text { low } \eta)\end{array}$ & $\begin{array}{l}25-48 \\
(\text { low } \eta)\end{array}$ & $\begin{array}{c}\text { Frit } 418, \\
48.8 \%\end{array}$ \\
\hline
\end{tabular}

\subsection{Impact of the $\mathrm{SO}_{4}$ Solubility Limit}

The projected operational windows shown in Table 5-1 through Table 5-3 were based on MAR assessments of the predicted properties. As previously noted, a $\mathrm{SO}_{4}$ solubility limit was not activated for this assessment and therefore did not or could not restrict or influence the projected operating windows. Previous $\mathrm{SO}_{4}$ solubility limits (in glass) have been set at $0.4 \mathrm{wt} \%$ (for SB1 and $\mathrm{SB} 2$ ) and $0.6 \mathrm{wt} \%$ (for SB3). The $0.6 \mathrm{wt} \%$ limit was specifically established for the Frit 418 - SB3 system (Peeler et al. (2004)) and may not be applicable for the SB4 system. A program is currently in progress to set the $\mathrm{SO}_{4}$ solubility limit for SB4, which is highly dependent upon the overall glass composition (sludge composition, frit selection, and WL all play a role). Table 5-4 provides guidance on the impact of the $\mathrm{SO}_{4}$ solubility limit on projected operating windows for SB4. In this table, the $\mathrm{SO}_{4}$ limit is varied from 0.4 to $0.6 \mathrm{wt} \%$ (in $0.1 \%$ increments) and the maximum WL that could be obtained (based solely on the assumed 
$\mathrm{SO}_{4}$ limit) is calculated based on the nominal $\mathrm{SO}_{4}$ content in sludge. For example, consider the SB4-only Baseline option where the normalized $\mathrm{SO}_{4}$ concentration in sludge is $1.098 \mathrm{wt} \%$ (see Table 4-2). If the $\mathrm{SO}_{4}$ solubility limit were set at $0.4 \mathrm{wt} \%$ (in glass), a maximum $\mathrm{WL}$ of $36.4 \%$ would be achievable (i.e., $0.4 / 1.098 * 100=36.4 \%$ ) at which higher WLs would exceed the $0.4 \mathrm{wt} \%$ limit. Comparing this upper WL to those projected in Table 5-1 through Table 5-3, the $0.4 \mathrm{wt} \% \mathrm{SO}_{4}$ limit would further restrict the projected operating windows for almost all frit/sludge combinations.

Table 5-4. Maximum WLs for Each SB4 Options as a Function of the $\mathrm{SO}_{4}$ Solubility Limit.

\begin{tabular}{|c|c|c|c|c||}
\hline \hline & $\begin{array}{c}\text { Sludge } \\
\text { SO }_{\mathbf{4}}\end{array}$ & $\begin{array}{c}\text { MAX } \\
\text { WL }\end{array}$ & $\begin{array}{c}\text { MAX } \\
\text { WL }\end{array}$ & $\begin{array}{c}\text { MAX } \\
\text { WL }\end{array}$ \\
\hline Type & $\mathbf{( w t ~} \mathbf{n})^{\mathbf{0 . 4}}$ & $\mathbf{0 . 5}$ & $\mathbf{0 . 6}$ \\
\hline SB4 Only Baseline & 1.098 & 36.4 & 45.5 & 54.6 \\
\hline SB4 Only Min Al & 1.095 & 36.5 & 45.7 & 54.8 \\
\hline SB4 Only Max Al & 1.109 & 36.1 & 45.1 & 54.1 \\
\hline & & & & \\
\hline 1100 Can Baseline & 1.099 & 36.4 & 45.5 & 54.6 \\
\hline 1100 Can 2nd Transfer, Baseline & 1.098 & 36.4 & 45.5 & 54.6 \\
\hline 1100 Can Min & 1.097 & 36.5 & 45.6 & 54.7 \\
\hline 1100 Can Max Al & 1.104 & 36.2 & 45.3 & 54.3 \\
\hline 1100 Can Min Ce & 1.097 & 36.5 & 45.6 & 54.7 \\
\hline 1100 Can Min Fe & 1.100 & 36.4 & 45.5 & 54.5 \\
\hline 1100 Can Max Mg & 1.099 & 36.4 & 45.5 & 54.6 \\
\hline 1100 Can Max Ni & 1.095 & 36.5 & 45.6 & 54.8 \\
\hline 1100 Can Max Ti & 1.103 & 36.3 & 45.3 & 54.4 \\
\hline & & & & \\
\hline 1200 Can Baseline & 1.098 & 36.4 & 45.5 & 54.6 \\
\hline Can 2nd Transfer, Baseline & 1.098 & 36.4 & 45.5 & 54.6 \\
\hline 1200 Can Min Al & 1.096 & 36.5 & 45.6 & 54.7 \\
\hline 1200 Can Max Al & 1.105 & 36.2 & 45.3 & 54.3 \\
\hline 1200 Can Max Ni & 1.095 & 36.5 & 45.6 & 54.8 \\
\hline 1200 Can Min Ce & 1.100 & 36.4 & 45.5 & 54.5 \\
\hline 1200 Can Min Mg & 1.097 & 36.5 & 45.6 & 54.7 \\
\hline 1200 Can Max Mg & 1.104 & 36.2 & 45.3 & 54.4 \\
\hline
\end{tabular}

Table 5-5 summarizes the impact of the $\mathrm{SO}_{4}$ solubility limit on the 1100 canister baseline option. The first column (labeled $\mathrm{SO}_{4}$ ) indicates the assumed $\mathrm{SO}_{4}$ limit (either "not activated", 0.4, 0.5, or 0.6). When the $\mathrm{SO}_{4}$ limit is "not activated", the projected operating windows are identical to those shown in Table 5-2 (typical WL intervals from 25 - mid- $40 \%$ 's). When a $0.4 \mathrm{wt} \% \mathrm{SO}_{4}$ limit is imposed in PCCS, the impact is significant as $\mathrm{SO}_{4}$ becomes the upper WL limiting property for this option (i.e., regardless of the frit selection, the maximum WLs would be limited to $36 \%$ ). Imposing a 0.5 or $0.6 \mathrm{wt} \% \mathrm{SO}_{4}$ limit in PCCS does not limit the projected windows for the 1100 canister baseline option (these systems remain either $T_{L}$ or low viscosity limited - the one exception is the Frit 417, 1100 Canister Baseline option with a $0.5 \mathrm{wt} \%$ $\mathrm{SO}_{4}$ limit). For this system, the projected operating window remains the same (relative to the "not activated" case) but now both $\mathrm{T}_{\mathrm{L}}$ and $\mathrm{SO}_{4}$ are limiting properties at $46 \% \mathrm{WL}$. 
WSRC-TR-2005-00103

Revision 0

Table 5-5. 1100 Canister Baseline Option - MAR Results with $\mathrm{SO}_{4}$ Activated

\begin{tabular}{||c|c|c|c|c|c|c||}
\hline \hline SO $_{4}$ & Frit 418 & Frit 426 & Frit 425 & Frit 417 & Frit 320 & Frit 431 \\
\hline $\begin{array}{c}\text { Not } \\
\text { activated }\end{array}$ & $\begin{array}{c}25-42 \\
\left(\mathrm{~T}_{\mathrm{L}}\right)\end{array}$ & $\begin{array}{c}25-43 \\
\left(\mathrm{~T}_{\mathrm{L}}\right)\end{array}$ & $\begin{array}{c}25-44 \\
\left(\mathrm{~T}_{\mathrm{L}}\right)\end{array}$ & $\begin{array}{c}25-45 \\
\left(\mathrm{~T}_{\mathrm{L}}\right)\end{array}$ & $\begin{array}{c}25-44 \\
(\text { low } \eta)\end{array}$ & $\begin{array}{c}\left(\Delta \mathrm{G}_{\mathrm{P}}\right) \\
27-41 \\
(\text { low } \eta)\end{array}$ \\
\hline $\mathbf{0 . 4}$ & $25-36$ & $25-36$ & $25-36$ & $25-36$ & $25-36$ & $\left(\Delta \mathrm{G}_{\mathrm{P}}\right)$ \\
& $\left(\mathrm{SO}_{4}\right)$ & $\left(\mathrm{SO}_{4}\right)$ & $\begin{array}{c}\left(\mathrm{SO}_{4}\right) \\
\left(\mathrm{SO}_{4}\right)\end{array}$ & $\begin{array}{c}\left.\mathrm{SO}_{4}\right) \\
27-36 \\
\left(\mathrm{SO}_{4}\right)\end{array}$ \\
\hline $\mathbf{0 . 5}$ & $25-42$ & $25-43$ & $25-44$ & $25-45$ & $25-44$ & $\left(\Delta \mathrm{G}_{\mathrm{P}}\right)$ \\
& $\left(\mathrm{T}_{\mathrm{L}}\right)$ & $\left(\mathrm{T}_{\mathrm{L}}\right)$ & $\left(\mathrm{T}_{\mathrm{L}}\right)$ & $\left(\mathrm{T}_{\mathrm{L}} / \mathrm{SO}_{4}\right)$ & $\begin{array}{c}27-41 \\
(\text { low } \eta)\end{array}$ & $\begin{array}{c}27 \\
(\text { low } \eta)\end{array}$ \\
\hline $\mathbf{0 . 6}$ & $25-42$ & $25-43$ & $25-44$ & $25-45$ & $25-44$ & $\left(\Delta \mathrm{G}_{\mathrm{P}}\right)$ \\
& $\left(\mathrm{T}_{\mathrm{L}}\right)$ & $\left(\mathrm{T}_{\mathrm{L}}\right)$ & $\left(\mathrm{T}_{\mathrm{L}}\right)$ & $\left(\mathrm{T}_{\mathrm{L}}\right)$ & $($ low $\eta)$ & $\begin{array}{c}27-41 \\
(\text { low } \eta)\end{array}$ \\
\hline
\end{tabular}

Although the impact of the various $\mathrm{SO}_{4}$ solubility limits is not summarized in tabular form for all 20 options, the most significant impact would be the imposition of a $0.4 \mathrm{wt} \%$ limit. This would have a significant (negative) impact on the projected operating windows for almost all sludge options being considered - limiting upper WLs to $36 \%$ or less. The $0.5 \mathrm{wt} \%$ limit (coupled with the nominal $\mathrm{SO}_{4}$ concentrations assumed in the sludge) becomes a limiting factor at $\sim 45 \% \mathrm{WL}$. Most of the operating windows would not be impacted with the $0.5 \mathrm{wt} \% \mathrm{SO}_{4}$ limit. The exceptions include the 1100 Canister "Max Al" and "Max Ti" options and the 1200 canister "Max Al" and "Max Mg" options. Upper WLs for these blending options with the $\mathrm{SO}_{4}$ limit deactivated exceed the $45 \% \mathrm{WL}$ mark.

Obviously the least imposing $\mathrm{SO}_{4}$ limit or constraint would be the $0.6 \mathrm{wt} \%$ case - which would allow projected operating windows to exceed $\sim 54 \% \mathrm{WL}$ prior to $\mathrm{SO}_{4}$ becoming a limiting factor based on the nominal $\mathrm{SO}_{4}$ values used. With the exception of the "Max Al" cases for all three primary classifications (SB4-only, 1100 canister, and 1200 canister), the $0.6 \mathrm{wt} \% \mathrm{SO}_{4}$ limit would not restrict projected operating windows. For the cases for which a $0.6 \mathrm{wt} \%$ limit would restrict the model-based upper WL, it is unlikely that DWPF would process SB4 at WLs this high (> 54\%) given the dependence or interaction between melt rate and WL and the impact on waste throughput.

\subsection{Frittability of Candidate Frits}

One factor to be considered during frit selection is the ability to manufacture or produce the desired frit composition. Based on the six candidate frits being evaluated, there are no primary concerns associated with the fabrication potential. The most refractory frit utilized in this assessment of SB4 options was Frit 418 , which has been manufactured by a vendor and used to support the processing of SB3.

\subsection{Impact of Washing}

Selecting among alternative washing scenarios for the HLW that is to comprise SB4 may be one of the challenging decisions facing the $\mathrm{CBU}$ as it develops the integrated flowsheet. Technical issues associated with the consideration of less washing include $\mathrm{SO}_{4}$ solubility, Chemical Process Cell (CPC) processing 
(including rheology, acid addition strategies, $\mathrm{H}_{2}$ generation, and nitrate/nitrite destruction), and the ability to counter the increased $\mathrm{Na}_{2} \mathrm{O}$ concentration in sludge versus that in frit. These technical issues must be balanced with the fact that the ability to transfer a less washed sludge also has beneficial impacts to the tank farm system and evaporators (less water being transferred). To provide some feedback to CBU on the impact of going to less-washed scenarios for the 20 cases outlined in this report, additional SB4 options were developed and evaluated as part of this study. Specifically, for each of the 20 cases provided by Lilliston (2005), a "1 less-washed" case was considered using the assumption that if a sludge is washed one less time its elemental Na concentration would increase by $2 \mathrm{wt} \%$ - all other components being renormalized. ${ }^{13}$ More specifically, the elemental Na concentration was increased by $2 \%$, then the elemental compositions were converted to oxides by multiplying the concentrations by the appropriate gravimetric factor. Since $\mathrm{SO}_{4}$ is a component that is specifically impacted by washing and has the potential to impact waste loading, an adjusted $\mathrm{SO}_{4}$ level was used for the one less wash case. A $1.14 \mathrm{wt} \%$ $\mathrm{SO}_{4}$ was added to each sludge option and the compositions were normalized. ${ }^{14}$ This led to the 1 lesswashed sludge compositions listed in Table 5-6. It is noted that the 20 options provided by Lilliston (2005) were based on different tank blending strategies and did not include various washing scenarios.

\footnotetext{
${ }^{13}$ The assumptions used to develop the "1-less" wash cases are known not to fully represent the actual compositional impacts due to washing (i.e., the concentrations of other oxides besides $\mathrm{Na}_{2} \mathrm{O}$ will be affected). However, the compositional information supplied by Lilliston (2005) was based on a nominal wash endpoint. Based on the results of the MAR assessments, the use of the " $\mathrm{Na}_{2} \mathrm{O}$ sliding scale" concept does provide the opportunity to assess the impact of less washing. That is, as the sludge becomes $\mathrm{more}^{\mathrm{Na}} \mathrm{O}_{2} \mathrm{O}-\mathrm{rich}$, one would expect the use of more refractory frits (i.e., those containing less $\mathrm{Na}_{2} \mathrm{O}$ ).

14 Based on personnel communication with J.M. Gillam, the $\mathrm{SO}_{4}$ value for a "1 less washed" scenario was projected to be $1.14 \mathrm{wt} \%$ (compared to the "baseline" wash with a $1.09 \mathrm{wt} \% \mathrm{SO}_{4}$ value). Therefore, not only did the $\mathrm{Na}_{2} \mathrm{O}$ concentration change for the " 1 less washed" sludges but the $\mathrm{SO}_{4}$ value as well. This number reflects a change in $\mathrm{SO}_{4}$ supernate from 0.0220 to $0.0235 \mathrm{M}$, with the respective insoluble solids and supernate density changes.
} 
Table 5-6. SB4 Blending Options - “1 Less Wash” as Normalized Oxide Concentrations (wt\%)

\begin{tabular}{|c|c|c|c|c|c|c|c|c|c|c|c|c|c|c|c|c|c|c|c|c|}
\hline & $\begin{array}{c}\text { SB4 } \\
\text { Only } \\
\text { Baseline }\end{array}$ & \begin{tabular}{|l} 
SB4 Only \\
Min Al, \\
Na, Mg, \\
Ti; Max \\
Ce, Fe, \\
Mg, Ni, U
\end{tabular} & $\begin{array}{c}\text { SB4 Only } \\
\text { Max Al, } \\
\text { Na, Mg, } \\
\text { Ti; Min Ce, } \\
\text { Fe, Mn, Ni, } \\
\text { U }\end{array}$ & $\begin{array}{c}1100 \\
\text { Can } \\
\text { Baseline }\end{array}$ & $\begin{array}{c}1100 \\
\text { Can 2nd } \\
\text { Transfer, } \\
\text { Baseline }\end{array}$ & \begin{tabular}{|c|}
1100 \\
$\mathrm{Can} \mathrm{Min}$ \\
$\mathrm{Al}, \mathrm{Na} ;$ \\
$\mathrm{Max} \mathrm{Ce}$, \\
$\mathrm{Fe}, \mathrm{Mn}$, \\
$\mathrm{U}$ \\
\end{tabular} & \begin{tabular}{|c|}
1100 \\
Can Max \\
Al, Na; \\
Min Mn, \\
Ni, U
\end{tabular} & $\begin{array}{c}1100 \\
\text { Can Min } \\
\text { Ce, Mg, } \\
\text { Ti }\end{array}$ & $\begin{array}{c}1100 \\
\text { Can Min } \\
\text { Fe }\end{array}$ & $\begin{array}{c}1100 \\
\text { Can Max } \\
\text { Mg }\end{array}$ & $\begin{array}{c}1100 \\
\text { Can Max } \\
\mathrm{Ni}\end{array}$ & $\begin{array}{c}1100 \\
\text { Can Max } \\
\text { Ti }\end{array}$ & $\begin{array}{c}1200 \\
\text { Can } \\
\text { Baseline }\end{array}$ & \begin{tabular}{|c|}
1200 \\
Can 2nd \\
Transfer, \\
Baseline
\end{tabular} & \begin{tabular}{|c}
1200 \\
Can Min \\
Al, Na; \\
Max Ce, \\
Fe, Mn, \\
U
\end{tabular} & \begin{tabular}{|c|}
1200 \\
$\mathrm{Can} \mathrm{Max}$ \\
$\mathrm{Al}, \mathrm{Na}$ \\
$\mathrm{Min} \mathrm{Fe}$, \\
$\mathrm{Mn}, \mathrm{Ni}$, \\
$\mathrm{U}$ \\
\end{tabular} & $\begin{array}{c}1200 \\
\text { Can Max } \\
\mathrm{Ni}\end{array}$ & $\begin{array}{c}1200 \\
\text { Can Min } \\
\text { Ce }\end{array}$ & $\begin{array}{c}1200 \\
\mathrm{Can} \mathrm{Min} \\
\mathrm{Mg}, \mathrm{Ti}\end{array}$ & $\begin{array}{c}1200 \\
\mathrm{Can} \mathrm{Max} \\
\mathrm{Mg}, \mathrm{Ti}\end{array}$ \\
\hline Oxide & $\mathrm{wt} \%$ & wt $\%$ & $\mathrm{wt} \%$ & $\mathrm{wt} \%$ & $\mathrm{wt} \%$ & wt $\%$ & $\mathrm{wt} \%$ & $\mathrm{wt} \%$ & $\mathrm{wt} \%$ & $\mathrm{wt} \%$ & $\mathrm{Wt} \%$ & $\mathrm{wt} \%$ & $\mathrm{wt} \%$ & $\mathrm{wt} \%$ & wt $\%$ & $\mathrm{wt} \%$ & $\mathrm{wt} \%$ & $\mathrm{wt} \%$ & $\mathrm{wt} \%$ & $\mathrm{wt} \%$ \\
\hline $\mathrm{Al}_{2} \mathrm{O}_{3}$ & 30.237 & 24.903 & 45.398 & 22.065 & 24.472 & 18.998 & 30.676 & 25.815 & 27.703 & 21.076 & 21.820 & 27.706 & 23.619 & 24.888 & 20.020 & 32.357 & 21.851 & 27.893 & 25.641 & 29.416 \\
\hline $\mathrm{BaO}$ & 0.182 & 0.220 & 0.079 & 0.157 & 0.164 & 0.172 & 0.105 & 0.180 & 0.153 & 0.158 & 0.195 & 0.111 & 0.161 & 0.165 & 0.180 & 0.101 & 0.195 & 0.153 & 0.179 & 0.107 \\
\hline $\mathrm{CaO}$ & 1.615 & 1.551 & 1.676 & 2.173 & 1.979 & 2.207 & 2.150 & 1.743 & 1.860 & 2.202 & 1.838 & 2.265 & 2.045 & 1.944 & 2.072 & 2.083 & 1.833 & 1.845 & 1.758 & 2.196 \\
\hline $\mathrm{Ce}_{2} \mathrm{O}_{3}$ & 0.185 & 0.182 & 0.184 & 0.202 & 0.195 & 0.204 & 0.200 & 0.186 & 0.188 & 0.202 & 0.190 & 0.204 & 0.197 & 0.194 & 0.198 & 0.197 & 0.189 & 0.188 & 0.186 & 0.201 \\
\hline $\mathrm{Cr}_{2} \mathrm{O}_{3}$ & 0.278 & 0.295 & 0.231 & 0.245 & 0.254 & 0.250 & 0.223 & 0.266 & 0.249 & 0.242 & 0.270 & 0.222 & 0.250 & 0.255 & 0.257 & 0.222 & 0.270 & 0.249 & 0.265 & 0.222 \\
\hline $\mathrm{CuO}$ & 0.077 & 0.082 & 056 & 0.082 & 0.079 & 0.085 & 0.070 & 0.077 & 0.072 & 0.080 & 0.082 & 0.073 & 0.080 & 0.079 & 0.083 & 0.067 & 0.082 & 0.072 & 0.077 & 0.071 \\
\hline $\mathrm{Fe}_{2} \mathrm{O}_{3}$ & 19.852 & 21.390 & 14.802 & 25.309 & 23.379 & 26.593 & 22.102 & 21.595 & 21.562 & 25.819 & 23.550 & 23.796 & 24.049 & 23.035 & 25.479 & 21.130 & 23.510 & 21.411 & 21.740 & 22.804 \\
\hline $\mathrm{K}_{2} \mathrm{O}$ & 1.860 & 1.459 & 2.983 & 0.997 & 1.262 & 0.740 & 1.660 & 1.448 & 1.523 & 0.883 & 1.104 & 1.386 & 1.167 & 1.307 & 0.869 & 1.813 & 1.106 & 1.542 & 1.428 & 1.541 \\
\hline $\mathrm{La}_{2} \mathrm{O}_{3}$ & 0.077 & 0.078 & 0.066 & 0.090 & 0.085 & 0.093 & 0.083 & 0.080 & 0.079 & 0.090 & 0.084 & 0.088 & 0.087 & 0.084 & 0.089 & 0.081 & 0.084 & 0.078 & 0.080 & 0.085 \\
\hline $\mathrm{MgO}$ & 0.343 & 0.325 & 0.399 & 1.890 & 1.386 & 2.042 & 1.781 & 0.853 & 1.218 & 2.089 & 1.125 & 2.087 & 1.567 & 1.300 & 1.714 & 1.609 & 1.117 & 1.187 & 0.894 & 1.913 \\
\hline $\mathrm{MnO}$ & 4.989 & 5.764 & 3.183 & 5.681 & 5.416 & 6.102 & 4.652 & 5.373 & 5.230 & 5.942 & 5.848 & 4.995 & 5.521 & 5.379 & 6.022 & 4.471 & 5.853 & 5.219 & 5.395 & 4.812 \\
\hline $\mathrm{Na}_{2} \mathrm{O}$ & 22.101 & 21.536 & 23.547 & 24.079 & 24.056 & 23.817 & 24.909 & 23.869 & 24.218 & 24.019 & 23.598 & 24.761 & 24.065 & 24.052 & 23.739 & 24.986 & 23.596 & 24.220 & 23.873 & 24.839 \\
\hline $\mathrm{NiO}$ & 5.708 & 7.565 & 1.215 & 3.615 & 4.247 & 4.221 & 1.417 & 5.447 & 4.147 & 3.683 & 5.903 & 1.469 & 4.021 & 4.355 & 4.824 & 1.389 & 5.918 & 4.182 & 5.387 & 1.440 \\
\hline $\mathrm{PbO}$ & 0.195 & 0.168 & 0.258 & 0.161 & 0.170 & 0.147 & 0.197 & 0.172 & 0.178 & 0.153 & 0.156 & 0.185 & 0.166 & 0.171 & 0.149 & 0.203 & 0.156 & 0.178 & 0.172 & 0.191 \\
\hline $\mathrm{SO}_{4}$ & 1.118 & 1.114 & 1.129 & 1.118 & 1.118 & 1.116 & 1.124 & 1.117 & 1.119 & 1.118 & 1.115 & 1.123 & 1.118 & 1.118 & 1.116 & 1.124 & 1.115 & 1.119 & 1.117 & 1.123 \\
\hline $\mathrm{SiO}_{2}$ & 2.343 & 1.989 & 3.281 & 2.659 & 2.537 & 2.544 & 3.117 & 2.321 & 2.608 & 2.677 & 2.223 & 3.101 & 2.587 & 2.522 & 2.436 & 3.133 & 2.224 & 2.607 & 2.335 & 3.118 \\
\hline $\mathrm{ThO}_{2}$ & 0.039 & 0.030 & 0.064 & 0.034 & 0.035 & 0.030 & 0.048 & 0.035 & 0.040 & 0.033 & 0.029 & 0.044 & 0.034 & 0.035 & 0.029 & 0.049 & 0.029 & 0.040 & 0.034 & 0.046 \\
\hline $\mathrm{TiO}_{2}$ & 0.012 & 0.010 & 0.021 & 0.021 & 0.018 & 0.020 & 0.024 & 0.014 & 0.018 & 0.022 & 0.015 & 0.025 & 0.019 & 0.018 & 0.018 & 0.024 & 0.015 & 0.018 & 0.015 & 0.025 \\
\hline $\mathrm{U}_{3} \mathrm{O}_{8}$ & 8.370 & 10.887 & 1.137 & 9.026 & 8.746 & 10.209 & 5.133 & 9.002 & 7.467 & 9.130 & 10.430 & 6.020 & 8.850 & 8.701 & 10.293 & 4.640 & 10.434 & 7.436 & 9.018 & 5.519 \\
\hline $\mathrm{ZnO}$ & 0.111 & 0.123 & 0.063 & 0.125 & 0.119 & 0.132 & 0.098 & 0.114 & 0.103 & 0.122 & 0.125 & 0.106 & 0.120 & 0.118 & 0.128 & 0.093 & 0.125 & 0.102 & 0.114 & 0.100 \\
\hline $\mathrm{ZrO}_{2}$ & 0.308 & 0.330 & 0.229 & 0.271 & 0.281 & 0.277 & 0.232 & 0.293 & 0.262 & 0.260 & 0.301 & 0.234 & 0.275 & 0.281 & 0.284 & 0.229 & 0.300 & 0.261 & 0.291 & 0.230 \\
\hline Total & 100.00 & 100.00 & 100.00 & 100.00 & 100.00 & 100.00 & 100.00 & 100.00 & 100.00 & 100.00 & 100.00 & 100.00 & 100.00 & 100.00 & 100.00 & 100.00 & 100.00 & 100.00 & 100.00 & $100.0 \# 3$ \\
\hline
\end{tabular}


As an example of the impact of less washing on the composition of a sludge option, consider the SB4 Only Baseline case. Based on the nominal wash endpoint, this case had $19.996 \mathrm{wt} \% \mathrm{Na}_{2} \mathrm{O}$ on a normalized basis (see Table 5-1). The "1 less-washed" case has $22.101 \mathrm{wt} \% \mathrm{Na}_{2} \mathrm{O}$ concentration on a normalized basis. Given the higher $\mathrm{Na}_{2} \mathrm{O}$ concentrations in these "less washed" cases, the expectation is that frits with less $\mathrm{Na}_{2} \mathrm{O}$ must be used to "compensate" for the increased $\mathrm{Na}_{2} \mathrm{O}$ concentration in sludge in order to retain projected operating windows. These "less-washed" options for the 20 SB4 cases were combined with the 6 frits listed in Table 4-3 and MAR assessments were performed. It should be noted that the $\mathrm{SO}_{4}$ concentrations in glass were used in the model-based assessments but a $\mathrm{SO}_{4}$ solubility limit was not activated in determining the projected operating windows. As previously demonstrated, the impact of the $\mathrm{SO}_{4}$ solubility limit can be significant.

Table A2 in the Appendix provides a summary of the MAR results for the 1 less-washed case for the 20 SB4 options. Tables 5-7, 5-8, and 5-9 summarize the projected operating windows for the "1 less washed" SB4only, 1100 canister, and 1200 canister cases, respectively.

Table 5-7. Impact of Washing Strategy on Operating Windows for SB4-Only Options - MAR Results

\begin{tabular}{||l|c|c|c|c|c|c||}
\hline Case & Frit 418 & Frit 426 & Frit 425 & Frit 417 & Frit 320 & Frit 431 \\
\hline Baseline & $\begin{array}{c}(\text { high } \eta) \\
28-38 \\
\left(\mathrm{~T}_{\mathrm{L}}\right)\end{array}$ & $\begin{array}{c}25-39 \\
\left(\mathrm{~T}_{\mathrm{L}}\right)\end{array}$ & $\begin{array}{c}25-40 \\
\left(\mathrm{~T}_{\mathrm{L}}\right)\end{array}$ & $\begin{array}{c}25-41 \\
\left(\mathrm{~T}_{\mathrm{L}}\right)\end{array}$ & $\begin{array}{c}25-42 \\
\left(\mathrm{~T}_{\mathrm{L}}\right)\end{array}$ & $\begin{array}{c}25-43 \\
\left(\mathrm{~T}_{\mathrm{L}}\right)\end{array}$ \\
\hline Max Al & - & - & $\begin{array}{c}(\text { high } \eta) \\
43-60\end{array}$ & $25-60$ & $25-60$ & $25-60$ \\
\hline Min Al & $\begin{array}{c}25-34 \\
\left(\mathrm{~T}_{\mathrm{L}}\right)\end{array}$ & $\begin{array}{c}25-35 \\
\left(\mathrm{~T}_{\mathrm{L}}\right)\end{array}$ & $\begin{array}{c}25-36 \\
\left(\mathrm{~T}_{\mathrm{L}}\right)\end{array}$ & $\begin{array}{c}25-37 \\
\left(\mathrm{~T}_{\mathrm{L}}\right)\end{array}$ & $\begin{array}{c}25-37 \\
\left(\mathrm{~T}_{\mathrm{L}}\right)\end{array}$ & $\begin{array}{c}25-38 \\
\left(\mathrm{~T}_{\mathrm{L}}\right)\end{array}$ \\
\hline
\end{tabular}


WSRC-TR-2005-00103

Revision 0

Table 5-8. Impact of Washing Strategy on Operating Windows for 1100 Canister Options - MAR Results

\begin{tabular}{|c|c|c|c|c|c|c|}
\hline & Frit 418 & Frit 426 & Frit 425 & Frit 417 & Frit 320 & Frit 431 \\
\hline Baseline & $\begin{array}{c}25-45 \\
\left(T_{L}\right)\end{array}$ & $\begin{array}{c}25-46 \\
\left(T_{L}\right)\end{array}$ & $\begin{array}{l}25-46 \\
\text { (low } \eta \text { ) }\end{array}$ & $\begin{array}{l}25-43 \\
\text { (low } \eta \text { ) }\end{array}$ & $\begin{array}{l}25-41 \\
\text { (low } \eta \text { ) }\end{array}$ & - \\
\hline $\begin{array}{c}2^{\text {nd }} \\
\text { transfer } \\
\text { baseline }\end{array}$ & $\begin{array}{c}25-43 \\
\left(T_{L}\right)\end{array}$ & $\begin{array}{c}25-44 \\
\left(\mathrm{~T}_{\mathrm{L}}\right)\end{array}$ & $\begin{array}{c}25-45 \\
\left(\mathrm{~T}_{\mathrm{L}}\right)\end{array}$ & $\begin{array}{c}25-46 \\
\left(T_{L} / \text { low } \eta\right)\end{array}$ & $\begin{array}{l}25-43 \\
(\text { low } \eta)\end{array}$ & - \\
\hline Min Al & $\begin{array}{c}25-43 \\
\left(T_{L}\right)\end{array}$ & $\begin{array}{c}25-44 \\
\left(T_{L}\right) \\
\end{array}$ & $\begin{array}{l}25-44 \\
(\text { low } \eta)\end{array}$ & $\begin{array}{l}25-41 \\
(\text { low } \eta)\end{array}$ & - & - \\
\hline $\operatorname{Max} \mathrm{Al}$ & $\begin{array}{c}25-56 \\
\left(\mathrm{~T}_{\mathrm{L}}\right)\end{array}$ & $\begin{array}{l}25-56 \\
(\text { low } \eta)\end{array}$ & $\begin{array}{l}25-54 \\
(\text { low } \eta)\end{array}$ & $\begin{array}{l}25-51 \\
(\text { low } \eta)\end{array}$ & $\begin{array}{l}25-49 \\
(\text { low } \eta)\end{array}$ & $\begin{array}{l}25-46 \\
\text { (low } \eta)\end{array}$ \\
\hline Min Ce & $\begin{array}{c}25-40 \\
\left(T_{L}\right)\end{array}$ & $\begin{array}{c}25-41 \\
\left(\mathrm{~T}_{\mathrm{L}}\right)\end{array}$ & $\begin{array}{c}25-42 \\
\left(\mathrm{~T}_{\mathrm{L}}\right)\end{array}$ & $\begin{array}{c}25-43 \\
\left(T_{L}\right)\end{array}$ & $\begin{array}{c}25-44 \\
\left(T_{L}\right)\end{array}$ & $\begin{array}{c}\left(\Delta \mathrm{G}_{\mathrm{P}}\right) \\
41-42 \\
(\text { low } \eta)\end{array}$ \\
\hline Min Fe & $\begin{array}{c}25-44 \\
\left(T_{L}\right)\end{array}$ & $\begin{array}{c}25-45 \\
\left(T_{L}\right)\end{array}$ & $\begin{array}{c}25-46 \\
\left(T_{L}\right)\end{array}$ & $\begin{array}{c}25-47 \\
\left(\mathrm{~T}_{\mathrm{L}}\right)\end{array}$ & $\begin{array}{l}25-47 \\
\text { (low } \eta \text { ) }\end{array}$ & $\begin{array}{c}\left(\Delta \mathrm{G}_{\mathrm{P}}\right) \\
33-44 \\
(\text { low } \eta)\end{array}$ \\
\hline Max Mg & $\begin{array}{c}25-44 \\
\left(\mathrm{~T}_{\mathrm{L}}\right)\end{array}$ & $\begin{array}{c}25-45 \\
\left(T_{L}\right) \\
\end{array}$ & $\begin{array}{l}25-45 \\
\text { (low } \eta)\end{array}$ & $\begin{array}{l}25-43 \\
(\text { low } \eta)\end{array}$ & $\begin{array}{c}25-34 \\
\left(\Delta \mathrm{G}_{\mathrm{P}}\right)\end{array}$ & - \\
\hline $\mathrm{Max} \mathrm{Ni}$ & $\begin{array}{c}25-39 \\
\left(\mathrm{~T}_{\mathrm{L}}\right)\end{array}$ & $\begin{array}{c}25-40 \\
\left(\mathrm{~T}_{\mathrm{L}}\right) \\
\end{array}$ & $\begin{array}{c}25-41 \\
\left(\mathrm{~T}_{\mathrm{L}}\right)\end{array}$ & $\begin{array}{c}25-42 \\
\left(T_{L}\right)\end{array}$ & $\begin{array}{c}25-42 \\
\left.\text { (low } \eta / T_{L}\right)\end{array}$ & - \\
\hline Max Ti & $\begin{array}{c}25-54 \\
\left(T_{L}\right)\end{array}$ & $\begin{array}{l}25-53 \\
(\text { low } \eta)\end{array}$ & $\begin{array}{l}25-50 \\
(\text { low } \eta)\end{array}$ & $\begin{array}{l}25-48 \\
(\text { low } \eta)\end{array}$ & $\begin{array}{l}25-45 \\
(\text { low } \eta)\end{array}$ & $\begin{array}{c}\left(\Delta \mathrm{G}_{\mathrm{P}}\right) \\
38-42 \\
(\text { low } \eta)\end{array}$ \\
\hline
\end{tabular}


WSRC-TR-2005-00103

Revision 0

Table 5-9. Impact of Washing Strategy on Operating Windows for 1200 Canister Options - MAR Results

\begin{tabular}{|c|c|c|c|c|c|c|}
\hline & Frit 418 & Frit 426 & Frit 425 & Frit 417 & Frit 320 & Frit 431 \\
\hline Baseline & $\begin{array}{c}25-44 \\
\left(T_{L}\right)\end{array}$ & $\begin{array}{c}25-45 \\
\left(T_{L}\right)\end{array}$ & $\begin{array}{c}25-46 \\
\left(T_{L}\right)\end{array}$ & $\begin{array}{l}25-45 \\
(\text { low } \eta)\end{array}$ & $\begin{array}{l}25-42 \\
(\text { low } \eta)\end{array}$ & - \\
\hline $\begin{array}{l}2^{\text {nd }} \\
\text { transfer } \\
\text { baseline }\end{array}$ & $\begin{array}{c}25-43 \\
\left(\mathrm{~T}_{\mathrm{L}}\right)\end{array}$ & $\begin{array}{c}25-44 \\
\left(T_{L}\right)\end{array}$ & $\begin{array}{c}25-45 \\
\left(T_{L}\right)\end{array}$ & $\begin{array}{c}25-46 \\
\left(T_{L} / \text { low } \eta\right)\end{array}$ & $\begin{array}{l}25-44 \\
\text { (low } \eta)\end{array}$ & - \\
\hline Min Al & $\begin{array}{c}25-41 \\
\left(\mathrm{~T}_{\mathrm{L}}\right)\end{array}$ & $\begin{array}{c}25-42 \\
\left(\mathrm{~T}_{\mathrm{L}}\right)\end{array}$ & $\begin{array}{l}25-43 \\
(\text { low } \eta)\end{array}$ & $\begin{array}{l}25-42 \\
(\text { low } \eta)\end{array}$ & $\begin{array}{c}25-30 \\
\left(\Delta \mathrm{G}_{\mathrm{P}}\right)\end{array}$ & - \\
\hline Max Al & $\begin{array}{c}\text { (high } \eta) \\
26-52 \\
\left(T_{L}\right)\end{array}$ & $\begin{array}{c}25-58 \\
\left(\mathrm{~T}_{\mathrm{L}} / \text { low } \eta\right)\end{array}$ & $\begin{array}{l}25-56 \\
(\text { low } \eta)\end{array}$ & $\begin{array}{l}25-54 \\
\text { (low } \eta)\end{array}$ & $\begin{array}{l}25-51 \\
(\text { low } \eta)\end{array}$ & $\begin{array}{l}25-48 \\
\text { (low } \eta \text { ) }\end{array}$ \\
\hline Max Ni & $\begin{array}{c}25-39 \\
\left(T_{L}\right)\end{array}$ & $\begin{array}{c}25-40 \\
\left(\mathrm{~T}_{\mathrm{L}}\right)\end{array}$ & $\begin{array}{c}25-41 \\
\left(T_{L}\right)\end{array}$ & $\begin{array}{c}25-42 \\
\left(T_{L}\right)\end{array}$ & $\begin{array}{c}25-42 \\
\left(T_{L} / \text { low } \eta\right)\end{array}$ & - \\
\hline Min Ce & $\begin{array}{c}25-44 \\
\left(T_{L}\right)\end{array}$ & $\begin{array}{c}25-45 \\
\left(\mathrm{~T}_{\mathrm{L}}\right)\end{array}$ & $\begin{array}{c}25-46 \\
\left(\mathrm{~T}_{\mathrm{L}}\right)\end{array}$ & $\begin{array}{c}25-47 \\
\left(T_{L}\right)\end{array}$ & $\begin{array}{l}25-47 \\
(\text { low } \eta)\end{array}$ & $\begin{array}{c}\left(\Delta \mathrm{G}_{\mathrm{P}}\right) \\
32-44 \\
(\text { low } \eta)\end{array}$ \\
\hline Min $\mathrm{Mg}$ & $\begin{array}{c}25-40 \\
\left(T_{L}\right)\end{array}$ & $\begin{array}{c}25-41 \\
\left(T_{L}\right)\end{array}$ & $\begin{array}{c}25-42 \\
\left(T_{L}\right)\end{array}$ & $\begin{array}{c}25-43 \\
\left(T_{L}\right)\end{array}$ & $\begin{array}{c}25-44 \\
\left(T_{L}\right)\end{array}$ & - \\
\hline Max Mg & $\begin{array}{c}25-55 \\
\left(T_{L}\right)\end{array}$ & $\begin{array}{l}25-55 \\
(\text { low } \eta)\end{array}$ & $\begin{array}{l}25-52 \\
(\text { low } \eta)\end{array}$ & $\begin{array}{l}25-50 \\
(\text { low } \eta)\end{array}$ & $\begin{array}{l}25-47 \\
(\text { low } \eta)\end{array}$ & $\begin{array}{c}\left(\Delta \mathrm{G}_{\mathrm{P}}\right) \\
29-44 \\
(\text { low } \eta)\end{array}$ \\
\hline
\end{tabular}

In general (and compared to the nominal sludge options previously discussed), the results suggest that as sludge becomes "enriched" in $\mathrm{Na}_{2} \mathrm{O}$ (i.e., as less-washed versions of these sludge options are considered) there is less dependency on higher alkali frits to yield glass systems with attractive operating windows. More specifically, coupling high alkali frits with the higher alkali sludges typically results in predictions of low viscosity or durability either dramatically reducing the operating window size or completely eliminating the window. Consider the 1100 canister baseline options with Frit 320 and Frit 431 . For the nominal wash scenario, both frits yield relatively large operating windows of $25-$ $44 \%$ and $27-41 \%$, respectively (see Table 5-2). When the "1 less washed" 1100 canister baseline option is utilized, the model based predictions restrict the use of Frit 431 (i.e., no operating window due to predictions of low viscosity and/or durability) and show a negative impact when Frit 320 is considered (reduces the upper WL to $41 \%$ down from $44 \%$ ). Again, this needed shift (reduction) in the frit $\mathrm{Na}_{2} \mathrm{O}$ content to compensate for the higher $\mathrm{Na}_{2} \mathrm{O}$ content in the sludge was expected and conforms to the use of the "sliding $\mathrm{Na}_{2} \mathrm{O}$ scale" concept.

Although the use of higher alkali frits is somewhat limited when considering the "less washed" sludge options, the projected operating windows for the more refractory frits appear to be enhanced relative to the nominal wash cases. Again, consider the 1100 canister baseline option coupled with Frit 418, Frit 426, Frit 425, and Frit 417. Table 5-10 summarizes the projected operating windows for the 1100 canister baseline nominal and "1 less washed" cases. The results indicate that the projected operating windows are enhanced with the use of the "less washed" sludge for each frit. This observation is in-line with preliminary assessments which indicated that the ability of the "sliding $\mathrm{Na}_{2} \mathrm{O}$ scale" concept to account for or balance the alkali content was less effective for sludges containing less $\mathrm{Na}_{2} \mathrm{O}$. The 
hypothesis is based on the need to have more $\mathrm{Na}_{2} \mathrm{O}$ in the sludge than in the frit. If there is more $\mathrm{Na}_{2} \mathrm{O}$ in the sludge than in the frit, then as WL increases, the $\mathrm{Na}_{2} \mathrm{O}$ content in the glass increases which (in general) should reduce $T_{L}$ and provide access to higher WLs for $T_{L}$-limited systems. If the $\mathrm{Na}_{2} \mathrm{O}$ content in the sludge is less than that in the frit, as WL increases, the glass (in general) becomes more refractory, and predictions of $\mathrm{T}_{\mathrm{L}}$ and/or high viscosity not only restrict access to higher WLs but begin to collapse the projected operating window altogether.

Table 5-10. Impact of Washing on the 1100 Canister Baseline Sludge Options.

\begin{tabular}{||c|c|c|c|c||}
\hline & Frit 418 & Frit 426 & Frit 425 & Frit 417 \\
\hline Baseline & $25-42$ & $25-43$ & $25-44$ & $25-45$ \\
& $\left(\mathrm{~T}_{\mathrm{L}}\right)$ & $\left(\mathrm{T}_{\mathrm{L}}\right)$ & $\left(\mathrm{T}_{\mathrm{L}}\right)$ & $\left(\mathrm{T}_{\mathrm{L}}\right)$ \\
\hline $\begin{array}{c}\text { Baseline } \\
\text { "1 less } \\
\text { wash" }\end{array}$ & $25-45$ & $25-46$ & $25-46$ & $25-43$ \\
$\left(\mathrm{~T}_{\mathrm{L}}\right)$ & $\left(\mathrm{T}_{\mathrm{L}}\right)$ & $\left(\mathrm{T}_{\mathrm{L}} /\right.$ low $\left.\eta\right)$ & $($ low $\eta)$ \\
\hline
\end{tabular}

Again, numerous comparisons can be made between the nominal and "less washed" SB4 options. Although the reader is encouraged to draw conclusions between or among various systems, the general results of the "washing" assessment suggest that frits are available that provide relatively large operating windows for the "less washed" cases. In fact, there appears to be some advantage of having more $\mathrm{Na}_{2} \mathrm{O}$ in the sludge with respect to the ability of the existing frits to enhance the projected operating windows. These latter two statements are based solely on model-predictions and do not account for the potential impacts of $\mathrm{SO}_{4}$ solubility issues, melt rate, and/or CPC processing issues that may necessitate a more-washed sludge. 
WSRC-TR-2005-00103

Revision 0

\subsection{SUMMARY}

The model-based assessments of nominal Sludge Batch 4 (SB4) compositions suggest that a viable frit candidate does not appear to be a limiting factor as the Closure Business Unit (CBU) considers various tank blending options and/or washing strategies. This statement is based solely on the projected operating windows derived from model predictions and does not include assessments of $\mathrm{SO}_{4}$ solubility or melt rate issues. The viable frit candidates covered a range of $\mathrm{Na}_{2} \mathrm{O}$ concentrations (from $8 \%$ to $13 \%$ ) using a "sliding $\mathrm{Na}_{2} \mathrm{O}$ scale" concept (i.e., $1 \%$ increase in $\mathrm{Na}_{2} \mathrm{O}$ being balanced by a $1 \%$ reduction in $\mathrm{SiO}_{2}$ ), which effectively balanced the alkali content of the incoming sludge with that in the frit to maintain and/or increase the projected operating window size while potentially leading to improved melt rate and/or waste loadings. This strategy or approach allows alternative tank blending strategies and/or different washing scenarios to be considered and accounted for in an effective manner without wholesale changes to the frit composition.

In terms of projected operating windows, in general, the sludge / frit systems evaluated resulted in waste loading intervals from 25 to the mid- $40 \%$ 's or even the mid-50\%'s. The results suggest that a single frit could be selected for use with all 20 options which indicates some degree of frit robustness with respect to sludge compositional variation. In fact, use of Frit 418 or Frit 320 (the "cornerstone" frits given previous processing experience in the Defense Waste Processing Facility (DWPF)) are plausible for most (if not all) options being considered.

However, the frit selection process also needs to consider potential processing issues such as melt rate. Based on historical trends between melt rate and total alkali content, one may elect to use the frit with the highest alkali content that still yields an acceptable operating window. However, other constraints may restrict access to higher waste loading or the proposed blending option being considered (e.g., sulfate content of the high-level waste and/or Chemical Processing Cell (CPC) issues may necessitate a more-washed sludge).

Although various washing scenarios were not provided by Lilliston (2005), projected alternative washing scenarios for the 20 nominal options were developed using very basic or rudimentary assumptions. Specifically, for each of the 20 cases provided, a 1 "less-washed" case was developed using the assumption that if a sludge is washed one less time its elemental $\mathrm{Na}$ concentration would increase by $2 \mathrm{wt} \%$ - all other components being renormalized. The results of this assessment demonstrated the practicality of imposing or using the "sliding $\mathrm{Na}_{2} \mathrm{O}$ scale" concept. As the sludge compositions become more $\mathrm{Na}_{2} \mathrm{O}$-rich, adjustments to $\mathrm{Na}_{2} \mathrm{O}$ concentrations in frit can be made to accommodate the impact of "less washing" while retaining relatively large projected operating windows. Although these model-based assessments indicate the ability to accommodate "less washed" sludges, technical issues associated with $\mathrm{SO}_{4}$ solubility and CPC processing (including rheology, acid addition strategies, $\mathrm{H}_{2}$ generation, and nitrate/nitrite destruction) must be addressed. If no technical show-stoppers are identified, then a business decision regarding the ability to transfer a less-washed sludge to DWPF must be made in light of the potential beneficial impacts to the tank farm system and evaporators (less water being sent).

Based on the results of this assessment, use of the new durability limits do allow the possible use of higher alkali frits for a given sludge system. This is reflected in the fact the assessments performed by Lilliston and Shah (2004) suggest that more refractory frits (lower $\mathrm{Na}_{2} \mathrm{O}$ content) would be the primary candidates for most SB4 options being considered. Their assessments were based on the use of the existing (more conservative) durability limits which restrict assess to higher alkali-based systems. With the use of the proposed durability limits by Edwards et al. (2003), access to higher alkali systems is 
observed, and assuming the trend between melt rate and total alkali content holds for the SB4 system, this could be extremely beneficial to DWPF in terms of enhanced melt rates and/or waste throughput. Again, the challenge will be to assess the robustness of a candidate frit to anticipated compositional changes and then use historical trends (coupled with experimental confirmation tests) with respect to melt rate to select an optimal system that is robust and yields high throughputs. 
WSRC-TR-2005-00103

Revision 0

\subsection{REFERENCES}

ASTM 2002. Standard Test Methods for Determining Chemical Durability of Nuclear Waste Glasses: The Product Consistency Test (PCT), ASTM C-1285-2002.

Brown KG, CM Jantzen, and G Ritzhaupt. 2001. Relating Liquidus Temperature to Composition for Defense Waste Processing Facility (DWPF) Process Control, WSRC-TR-2001-00520, Westinghouse Savannah River Company, Aiken, South Carolina.

Brown, KG, RL Postles, and TB Edwards, 2002. SME Acceptability Determination for DWPF Process Control, WSRC-TR-95-0364, Revision 4, Westinghouse Savannah River Company, Aiken, South Carolina.

Edwards, TB, DK Peeler, and SL Marra. 2003. Revisiting the Prediction Limits for Acceptable Durability, WSRC-TR-2003-00510, Revision 0, Westinghouse Savannah River Company, Aiken, South Carolina.

Jantzen, CM, JB Pickett, KG Brown, TB Edwards, and DC Beam. 1995. Process/Product Models for the Defense Waste Processing Facility (DWPF): Part I. Predicting Glass Durability from Composition Using a Thermodynamic Hydration Energy Reaction Model (THERMO), WSRC-TR93-672, Revision 1, Volume 1, Westinghouse Savannah River Company, Aiken, South Carolina.

Lilliston, GR. 2005. Development of Elemental Sludge Compositions for Variations of Sludge Batch 4 (SB4), CBU-PIT-2004-00011, Revision 1, Westinghouse Savannah River Company, Aiken, South Carolina.

Peeler, DK and TB Edwards. 2002. Frit Development for Sludge Batch 3, WSRC-TR-2002-00491, Revision 0, Westinghouse Savannah River Company, Aiken, South Carolina.

Peeler, DK and ME Smith. 2004. Investigation to Increase the Overall Waste Throughput in the DWPF Melter, WSRC-RP-2004-00713, Revision 0, Westinghouse Savannah River Company, Aiken, South Carolina.

Peeler, DK. 2004. Sludge Batch 4 and MCU Frit Optimization, Task Technical and QA Plan, WSRC-TR-2004-00746, Revision 0, Westinghouse Savannah River Company, Aiken, South Carolina.

Peeler, DK, CC Herman, ME Smith, TH Lorier, DR Best, TB Edwards, and MA Baich. 2004. An Assessment of the Sulfate Solubility Limit for the Frit 418 - SB2/3 system, WSRC-TR-2004-00081, Revision 0, Westinghouse Savannah River Company, Aiken, South Carolina.

Shah, HB, GR Lilliston, and JM Gillam. Preliminary Blending, Washing, Additions, Feed and Glass Qualification Strategies for the Combination of Sludge Batch 4 (Tanks 4, 5, 6, 8, and 11) with Sludge Batch 3 as Feed into DWPF, CBU-PIT-2004-00021, Revision 0, Westinghouse Savannah River Company, Aiken, South Carolina.

Washburn, FA. 2004. Sludge Batch 4 and MCU Frit Optimization, Technical Task Request, HLW/DWPF/TTR-2004-0026, Revision 0, Westinghouse Savannah River Company, Aiken, South Carolina. 


\subsection{APPENDIX A}

\section{Results of MAR Assessments for SB4 Options}


Table A1. MAR Results and Various Predicted Properties for the Nominal SB4 Blending Options.

\begin{tabular}{|c|c|c|c|c|c|c|c|c|c|c|c|}
\hline Type & $\begin{array}{c}\text { Frit } \\
\text { ID }\end{array}$ & $\begin{array}{l}\text { Min } \\
\text { WL }\end{array}$ & $\begin{array}{l}\text { Max } \\
\text { WL }\end{array}$ & $\begin{array}{c}\text { Limited } \\
\text { Below By }\end{array}$ & $\begin{array}{c}\text { Limited } \\
\text { Above By }\end{array}$ & $\begin{array}{c}\begin{array}{c}\text { Del Gp } \\
\text { (min) }\end{array} \\
\text { (m) }\end{array}$ & $\begin{array}{c}\text { Visc } \\
\text { (min) }\end{array}$ & $\begin{array}{c}\text { TL } \\
\text { (min) }\end{array}$ & $\begin{array}{c}\text { Del Gp } \\
\text { (max) }\end{array}$ & Visc (max) & TL (max) \\
\hline SB4 Only Baseline & 320 & 25 & 40 & & $\mathrm{TL}$ & -11.6951 & 50.37 & 790.7 & -10.8755 & 66.81 & 1000.1 \\
\hline SB4 Only Baseline & 417 & 25 & 39 & & TL & -11.0022 & 59.3 & 801.9 & -10.3665 & 76.71 & 998.2 \\
\hline SB4 Only Baseline & 418 & 33 & 36 & hvisc & $\mathrm{TL}$ & -8.7817 & 94.1 & 956 & -8.7286 & 99.65 & 994.1 \\
\hline SB4 Only Baseline & 425 & 25 & 38 & & TL & -10.3092 & 69.48 & 813.5 & -9.839 & 87.75 & 996.6 \\
\hline SB4 Only Baseline & 426 & 25 & 37 & & $\mathrm{TL}$ & -9.6162 & 81.04 & 825.5 & -9.2931 & 100.03 & 995.2 \\
\hline SB4 Only Baseline & 431 & 25 & 40 & & $\mathrm{TL}$ & -12.3881 & 43.6 & 779.8 & -11.4299 & 57.97 & 990.6 \\
\hline SB4 Only Baseline & 441 & 30 & 42 & Del Gp & $\overline{T L}$ & -13.3623 & 30.72 & 837.9 & -12.3739 & 39.66 & 995.7 \\
\hline SB4 Only Max Al, Na, Mg, Ti; Min Ce, Fe, Mn, Ni, U & 320 & 25 & 60 & & & -10.7009 & 90.55 & 721.4 & -7.3962 & 95.19 & 971.9 \\
\hline SB4 Only Max Al, Na, Mg, Ti; Min Ce, Fe, Mn, Ni, U & 417 & . & . & & & . & . & . & . & . & . \\
\hline SB4 Only Max Al, Na, Mg, Ti; Min Ce, Fe, Mn, Ni, U & 418 & . & . & & & . & . & . & . & . & . \\
\hline SB4 Only Max Al, Na, Mg, Ti; Min Ce, Fe, Mn, Ni, U & 425 & . & . & & & . & . & . & . & . & . \\
\hline SB4 Only Max Al, Na, Mg, Ti; Min Ce, Fe, Mn, Ni, U & 426 & & . & & & . & & . & . & . & . \\
\hline SB4 Only Max Al, Na, Mg, Ti; Min Ce, Fe, Mn, Ni, U & 431 & 25 & 60 & & & -11.3938 & 78.95 & 713.5 & -7.7658 & 83.64 & 968.9 \\
\hline SB4 Only Max Al, Na, Mg, Ti; Min Ce, Fe, Mn, Ni, U & 441 & 25 & 60 & & & -12.7798 & 59.3 & 698.2 & -8.505 & 63.89 & 962.8 \\
\hline SB4 Only Min Al, Na, Mg, Ti; Max Ce, Fe, Mg, Ni, U & 320 & 25 & 35 & & $\mathrm{TL}$ & -12.0464 & 47.53 & 817.8 & -11.6404 & 60.27 & 984.8 \\
\hline SB4 Only Min Al, Na, Mg, Ti; Max Ce, Fe, Mg, Ni, U & 417 & 25 & 35 & & TL & -11.3534 & 54.8 & 830.5 & -11.0398 & 69.32 & 997.1 \\
\hline SB4 Only Min Al, Na, Mg, Ti; Max Ce, Fe, Mg, Ni, U & 418 & 27 & 32 & hvisc & $\mathrm{TL}$ & -9.2672 & 88.53 & 907.4 & -9.249 & 99.03 & 990.6 \\
\hline SB4 Only Min Al, Na, Mg, Ti; Max Ce, Fe, Mg, Ni, U & 425 & 25 & 34 & & TL & -10.6604 & 64.61 & 843.6 & -10.4614 & 79.42 & 994.7 \\
\hline SB4 Only Min Al, Na, Mg, Ti; Max Ce, Fe, Mg, Ni, U & 426 & 25 & 33 & & TL & -9.9674 & 75.81 & 857.2 & -9.8644 & 90.67 & 992.5 \\
\hline SB4 Only Min Al, Na, Mg, Ti; Max Ce, Fe, Mg, Ni, U & 431 & 25 & 36 & & TL & -12.7394 & 39.94 & 805.6 & -12.1912 & 52.21 & 987.9 \\
\hline SB4 Only Min Al, Na, Mg, Ti; Max Ce, Fe, Mg, Ni, U & 441 & 36 & 38 & Del Gp & TL & -13.3739 & 27.72 & 965 & -13.2373 & 29.43 & 994.7 \\
\hline 1100 Can Baseline & 320 & 25 & 44 & & lvisc & -12.7645 & 24.51 & 741.7 & -12.5389 & 51.08 & 989.7 \\
\hline 1100 Can Baseline & 417 & 25 & 45 & & TL & -12.0715 & 27.03 & 752.8 & -12.0189 & 58.85 & 1009.7 \\
\hline 1100 Can Baseline & 418 & 25 & 42 & & $\mathrm{TL}$ & -10.419 & 47.81 & 788.4 & -9.9925 & 88.04 & 1008.2 \\
\hline 1100 Can Baseline & 425 & 25 & 44 & & $\mathrm{TL}$ & -11.5041 & 32.9 & 764.2 & -11.3785 & 67.55 & 1008.9 \\
\hline 1100 Can Baseline & 426 & 25 & 43 & & $\mathrm{TL}$ & -10.9708 & 39.78 & 776.1 & -10.6855 & 77.25 & 1008.4 \\
\hline 1100 Can Baseline & 431 & 27 & 41 & Del Gp & lvisc & -13.4153 & 24.36 & 762.1 & -13.1197 & 41.56 & 946.9 \\
\hline 1100 Can Baseline & 441 & & . & & & . & & . & . & . & . \\
\hline
\end{tabular}




\begin{tabular}{|c|c|c|c|c|c|c|c|c|c|c|c|}
\hline Type & $\begin{array}{l}\text { Frit } \\
\text { ID }\end{array}$ & $\begin{array}{l}\text { Min } \\
\text { WL }\end{array}$ & $\begin{array}{l}\text { Max } \\
\text { WL } \\
\end{array}$ & $\begin{array}{c}\text { Limited } \\
\text { Below By }\end{array}$ & $\begin{array}{c}\text { Limited } \\
\text { Above By }\end{array}$ & $\begin{array}{c}\begin{array}{c}\text { Del Gp } \\
\text { (min) }\end{array} \\
\end{array}$ & $\begin{array}{c}\text { Visc } \\
\text { (min) }\end{array}$ & $\begin{array}{c}\text { TL } \\
\text { (min) }\end{array}$ & $\begin{array}{c}\text { Del Gp } \\
(\max )\end{array}$ & Visc (max) & TL $(\max )$ \\
\hline 1100 Can 2nd Transfer, Baseline & 320 & 25 & 44 & & $\mathrm{TL}$ & -12.5731 & 28.43 & 752.7 & -12.202 & 54.48 & 1000.9 \\
\hline 1100 Can 2nd Transfer, Baseline & 417 & 25 & 43 & & $\mathrm{TL}$ & -11.8801 & 34.42 & 763.7 & -11.6948 & 62.71 & 999.6 \\
\hline 1100 Can 2nd Transfer, Baseline & 418 & 25 & 40 & & TL & -10.0625 & 58.93 & 799.2 & -9.8011 & 93.6 & 997.4 \\
\hline 1100 Can 2nd Transfer, Baseline & 425 & 25 & 42 & & TL & -11.1871 & 41.41 & 775.1 & -11.1692 & 71.92 & 998.6 \\
\hline 1100 Can 2nd Transfer, Baseline & 426 & 25 & 41 & & TL & -10.6251 & 49.54 & 786.9 & -10.4941 & 82.19 & 997.8 \\
\hline 1100 Can 2nd Transfer, Baseline & 431 & 25 & 43 & & lvisc & -13.266 & 25.56 & 742 & -12.7482 & 47.14 & 980.9 \\
\hline 1100 Can 2nd Transfer, Baseline & 441 & . & . & & &. & . &. &. & . & . \\
\hline 1100 Can Min Al, Na; Max Ce, Fe, Mn, U & 320 & 25 & 41 & & lvisc & -12.9716 & 24.82 & 746.8 & -12.9142 & 47.91 & 971.7 \\
\hline 1100 Can Min Al, Na; Max Ce, Fe, Mn, U & 417 & 25 & 43 & & $\mathrm{TL}$ & -12.3803 & 25.94 & 758.4 & -12.2786 & 55.24 & 1005.9 \\
\hline 1100 Can Min Al, Na; Max Ce, Fe, Mn, U & 418 & 25 & 40 & & TL & -10.7002 & 46.32 & 795.8 & -10.1996 & 82.86 & 1004.5 \\
\hline 1100 Can Min Al, Na; Max Ce, Fe, Mn, U & 425 & 25 & 42 & & TL & -11.8388 & 31.68 & 770.4 & -11.5856 & 63.47 & 1005.1 \\
\hline 1100 Can Min Al, Na; Max Ce, Fe, Mn, U & 426 & 25 & 41 & & TL & -11.2787 & 38.42 & 782.9 & -10.8926 & 72.64 & 1004.6 \\
\hline 1100 Can Min Al, Na; Max Ce, Fe, Mn, U & 431 & . & . & & & . & . & . & . & . & . \\
\hline 1100 Can Min Al, Na; Max Ce, Fe, Mn, U & 441 & . & . & & & . & . & . & . & . & . \\
\hline 1100 Can Max Al, Na; Min Mn, Ni, U & 320 & 25 & 53 & & lvisc & -12.2079 & 25.61 & 715.3 & -11.252 & 60.89 & 991.3 \\
\hline 1100 Can Max Al, Na; Min Mn, Ni, U & 417 & 25 & 54 & & $\mathrm{TL}$ & -11.5149 & 28.23 & 724.7 & -10.7928 & 69.96 & 1003.9 \\
\hline 1100 Can Max Al, Na; Min Mn, Ni, U & 418 & 27 & 51 & hvisc & TL & -9.5093 & 49.05 & 781.3 & -9.4415 & 99.81 & 1002.5 \\
\hline 1100 Can Max Al, Na; Min Mn, Ni, U & 425 & 25 & 53 & & $\mathrm{TL}$ & -10.8219 & 34.14 & 734.4 & -10.3834 & 80.09 & 1003.2 \\
\hline 1100 Can Max Al, Na; Min Mn, Ni, U & 426 & 25 & 52 & & $\mathrm{TL}$ & -10.1289 & 41.04 & 744.4 & -9.9556 & 91.36 & 1002.7 \\
\hline 1100 Can Max Al, Na; Min Mn, Ni, U & 431 & 25 & 50 & & lvisc & -12.9008 & 25.27 & 706.1 & -11.8164 & 52.79 & 963.7 \\
\hline 1100 Can Max Al, Na; Min Mn, Ni, U & 441 & 40 & 42 & Del Gp & lvisc & -13.359 & 25.14 & 864.4 & -13.2352 & 26.81 & 883.4 \\
\hline 1100 Can Min Ce, Mg, Ti & 320 & 25 & 41 & & $\mathrm{TL}$ & -12.4479 & 35.59 & 770.9 & -12.0553 & 57.1 & 993.3 \\
\hline 1100 Can Min Ce, Mg, Ti & 417 & 25 & 41 & & $\mathrm{TL}$ & -11.7549 & 41.14 & 782.2 & -11.5101 & 65.7 & 1003.3 \\
\hline 1100 Can Min Ce, Mg, Ti & 418 & 25 & 38 & & $\mathrm{TL}$ & -9.8374 & 68.85 & 818.6 & -9.6759 & 97.92 & 1000.3 \\
\hline 1100 Can Min Ce, Mg, Ti & 425 & 25 & 40 & & $\mathrm{TL}$ & -11.0619 & 49.11 & 793.9 & -10.971 & 75.31 & 1002 \\
\hline 1100 Can Min Ce, Mg, Ti & 426 & 25 & 39 & & $\mathrm{TL}$ & -10.4134 & 58.3 & 806 & -10.3689 & 86.02 & 1001 \\
\hline 1100 Can Min Ce, Mg, Ti & 431 & 25 & 42 & & $\mathrm{TL}$ & -13.1409 & 29.52 & 760 & -12.5666 & 49.43 & 995.2 \\
\hline 1100 Can Min Ce, Mg, Ti & 441 & $\cdot$ & . & & & . & . & . & . & . & . \\
\hline 1100 Can Min Fe & 320 & 25 & 45 & & $\mathrm{TL}$ & -12.3563 & 32.67 & 753.2 & -11.7924 & 58.8 & 1002.1 \\
\hline 1100 Can Min Fe & 417 & 25 & 44 & & $\mathrm{TL}$ & -11.6634 & 39.25 & 763.8 & -11.3031 & 67.62 & 1000.8 \\
\hline
\end{tabular}




\begin{tabular}{|c|c|c|c|c|c|c|c|c|c|c|c|}
\hline Type & $\begin{array}{l}\text { Frit } \\
\text { ID }\end{array}$ & $\begin{array}{l}\text { Min } \\
\text { WL }\end{array}$ & $\begin{array}{l}\text { Max } \\
\text { WL }\end{array}$ & $\begin{array}{c}\text { Limited } \\
\text { Below By }\end{array}$ & $\begin{array}{c}\text { Limited } \\
\text { Above By }\end{array}$ & $\begin{array}{c}\text { Del Gp } \\
\text { (min) }\end{array}$ & $\begin{array}{c}\text { Visc } \\
\text { (min) }\end{array}$ & $\begin{array}{c}\text { TL } \\
(\mathrm{min})\end{array}$ & $\begin{array}{c}\text { Del Gp } \\
(\max )\end{array}$ & Visc (max) & TL (max) \\
\hline 1100 Can Min Fe & 418 & 26 & 41 & hvisc & $\mathrm{TL}$ & -9.7246 & 65.82 & 813.2 & -9.5931 & 98.49 & 998.6 \\
\hline 1100 Can Min Fe & 425 & 25 & 43 & & $\overline{T L}$ & -10.9704 & 46.88 & 774.8 & -10.7954 & 77.47 & 999.8 \\
\hline 1100 Can Min Fe & 426 & 25 & 42 & & $\mathrm{TL}$ & -10.2774 & 55.7 & 786.1 & -10.2692 & 88.44 & 999 \\
\hline 1100 Can Min Fe & 431 & 25 & 46 & & $\mathrm{TL}$ & -13.0493 & 27.03 & 742.8 & -12.2631 & 50.94 & 1003.6 \\
\hline 1100 Can Min Fe & 441 & . & . & & & . & . & . & . & . & . \\
\hline 1100 Can Max Mg & 320 & 25 & 43 & & lvisc & -12.8438 & 24.59 & 742 & -12.6872 & 50.02 & 982 \\
\hline 1100 Can Max Mg & 417 & 25 & 44 & & $\mathrm{TL}$ & -12.161 & 27.12 & 753.2 & -12.1508 & 57.64 & 1002.8 \\
\hline 1100 Can Max Mg & 418 & 25 & 41 & & $\mathrm{TL}$ & -10.524 & 48 & 789.2 & -10.0718 & 86.29 & 1001.2 \\
\hline 1100 Can Max Mg & 425 & 25 & 43 & & TL & -11.6338 & 33.01 & 764.8 & -11.4578 & 66.18 & 1001.9 \\
\hline 1100 Can Max Mg & 426 & 25 & 42 & & TL & -11.0881 & 39.93 & 776.8 & -10.7648 & 75.7 & 1001.4 \\
\hline 1100 Can Max Mg & 431 & 32 & 40 & Del Gp & lvisc & -13.4112 & 24.45 & 835.2 & -13.2677 & 34.13 & 937.7 \\
\hline 1100 Can Max Mg & 441 & . & . & & & . & . & . & . & . & . \\
\hline 1100 Can Max Ni & 320 & 25 & 40 & & TL & -12.7227 & 30.97 & 774.9 & -12.5195 & 52.27 & 997.3 \\
\hline 1100 Can Max Ni & 417 & 25 & 39 & & $\mathrm{TL}$ & -12.0297 & 37.42 & 786.9 & -11.9694 & 60.21 & 995.6 \\
\hline 1100 Can Max Ni & 418 & 25 & 36 & & $\overline{T L}$ & -10.2083 & 63.73 & 825.4 & -9.9507 & 90.06 & 992.2 \\
\hline 1100 Can Max Ni & 425 & 25 & 38 & & $\overline{T L}$ & -11.4009 & 44.94 & 799.3 & -11.3367 & 69.11 & 994.2 \\
\hline 1100 Can Max Ni & 426 & 25 & 37 & & $\overline{T L}$ & -10.8138 & 53.67 & 812.1 & -10.6437 & 79.03 & 993 \\
\hline 1100 Can Max Ni & 431 & 25 & 41 & & TL lvisc & -13.4157 & 25.47 & 763.4 & -13.0511 & 45.19 & 999.4 \\
\hline 1100 Can Max Ni & 441 & . & . & & & . & . & . & . & . & . \\
\hline 1100 Can Max Ti & 320 & 25 & 49 & & lvisc & -12.4189 & 25.2 & 715.4 & -11.8022 & 56.83 & 973.1 \\
\hline 1100 Can Max Ti & 417 & 25 & 52 & & lvisc & -11.7259 & 25.05 & 725.1 & -11.2816 & 65.36 & 1003 \\
\hline 1100 Can Max Ti & 418 & 25 & 50 & & $\mathrm{TL}$ & -9.9286 & 42.27 & 756.3 & -9.647 & 97.3 & 1009 \\
\hline 1100 Can Max Ti & 425 & 25 & 52 & & $\mathrm{TL}$ & -11.0329 & 28.94 & 735.2 & -10.8381 & 74.9 & 1009.6 \\
\hline 1100 Can Max Ti & 426 & 25 & 51 & & $\mathrm{TL}$ & -10.3926 & 35.09 & 745.6 & -10.34 & 85.51 & 1009.2 \\
\hline 1100 Can Max Ti & 431 & 25 & 46 & & lvisc & -13.1119 & 24.9 & 705.9 & -12.3783 & 49.22 & 941 \\
\hline 1100 Can Max Ti & 441 & . & . & & & . & . & . & . & . & . \\
\hline 1200 Can Baseline & 320 & 25 & 45 & & TL lvisc & -12.6418 & 25.73 & 748.7 & -12.3063 & 53.27 & 1007.5 \\
\hline 1200 Can Baseline & 417 & 25 & 44 & & $\mathrm{TL}$ & -11.9489 & 31.29 & 759.8 & -11.8056 & 61.34 & 1006.3 \\
\hline 1200 Can Baseline & 418 & 25 & 41 & & $\mathrm{TL}$ & -10.1928 & 54.26 & 795.3 & -9.8699 & 91.61 & 1004.4 \\
\hline 1200 Can Baseline & 425 & 25 & 43 & & TL & -11.2865 & 37.82 & 771.2 & -11.2559 & 70.36 & 1005.4 \\
\hline
\end{tabular}




\begin{tabular}{|c|c|c|c|c|c|c|c|c|c|c|c|}
\hline Type & $\begin{array}{l}\text { Frit } \\
\text { ID }\end{array}$ & $\begin{array}{l}\text { Min } \\
\text { WL }\end{array}$ & $\begin{array}{l}\text { Max } \\
\text { WL }\end{array}$ & $\begin{array}{c}\text { Limited } \\
\text { Below By }\end{array}$ & $\begin{array}{c}\text { Limited } \\
\text { Above By }\end{array}$ & $\begin{array}{c}\begin{array}{c}\text { Del Gp } \\
\text { (min) }\end{array} \\
\text { (m) }\end{array}$ & $\begin{array}{c}\text { Visc } \\
\text { (min) }\end{array}$ & $\begin{array}{c}\text { TL } \\
\text { (min) }\end{array}$ & $\begin{array}{c}\text { Del Gp } \\
(\max )\end{array}$ & Visc (max) & TL (max) \\
\hline 1200 Can Baseline & 426 & 25 & 42 & & $\mathrm{TL}$ & -10.7489 & 45.43 & 783 & -10.5629 & 80.43 & 1004.7 \\
\hline 1200 Can Baseline & 431 & 25 & 42 & & lvisc & -13.3348 & 25.43 & 738.1 & -12.8925 & 46.08 & 965.7 \\
\hline 1200 Can Baseline & 441 & . & . & & & . & . & . & . & . & . \\
\hline 1200 Can 2nd Transfer, Baseline & 320 & 25 & 44 & & $\mathrm{TL}$ & -12.5407 & 29.18 & 754.4 & -12.1451 & 55.1 & 1002.5 \\
\hline 1200 Can 2nd Transfer, Baseline & 417 & 25 & 43 & & TL & -11.8478 & 35.28 & 765.4 & $\begin{array}{l}-11.6393 \\
\end{array}$ & 63.42 & 1001.2 \\
\hline 1200 Can 2nd Transfer, Baseline & 418 & 25 & 40 & & TL & -10.0108 & 60.2 & 800.8 & -9.7688 & 94.61 & 998.9 \\
\hline 1200 Can 2nd Transfer, Baseline & 425 & 25 & 42 & & $\mathrm{TL}$ & -11.1548 & 42.4 & 776.8 & -11.1149 & 72.72 & 1000.1 \\
\hline 1200 Can 2nd Transfer, Baseline & 426 & 25 & 41 & & $\mathrm{TL}$ & -10.5721 & 50.67 & 788.6 & -10.4618 & 83.09 & 999.4 \\
\hline 1200 Can 2nd Transfer, Baseline & 431 & 25 & 44 & & lvisc & -13.2337 & 25.09 & 743.7 & -12.6625 & 47.68 & 993.4 \\
\hline 1200 Can 2nd Transfer, Baseline & 441 & . & . & & & . & . & . & . & . & . \\
\hline 1200 Can Min Al, Na; Max Ce, Fe, Mn, U & 320 & 25 & 42 & & TL lvisc & -12.8827 & 25.2 & 756.8 & -12.7612 & 49.45 & 997.7 \\
\hline 1200 Can Min Al, Na; Max Ce, Fe, Mn, U & 417 & 25 & 41 & & TL & -12.2232 & 30.73 & 768.6 & -12.1897 & 57.01 & 996.3 \\
\hline 1200 Can Min Al, Na; Max Ce, Fe, Mn, U & 418 & 25 & 39 & & TL & -10.5281 & 51.42 & 806.4 & -10.1107 & 85.42 & 1006.4 \\
\hline 1200 Can Min Al, Na; Max Ce, Fe, Mn, U & 425 & 25 & 40 & & TL & -11.6667 & 37.24 & 780.7 & -11.4967 & 65.47 & 995.2 \\
\hline 1200 Can Min Al, Na; Max Ce, Fe, Mn, U & 426 & 25 & 40 & & $\overline{T L}$ & -11.1123 & 42.87 & 793.3 & -10.8037 & 74.91 & 1006.7 \\
\hline 1200 Can Min Al, Na; Max Ce, Fe, Mn, U & 431 & 35 & 39 & Del Gp & lvisc & -13.4118 & 25.02 & 896.7 & -13.3463 & 29.81 & 949.8 \\
\hline 1200 Can Min Al, Na; Max Ce, Fe, Mn, U & 441 & . & . & & & . & . & . & . & . & . \\
\hline 1200 Can Max Al, Na; Min Fe, Mn, Ni, U & 320 & 25 & 56 & & TL lvisc & -12.0878 & 25.44 & 714.8 & -10.8808 & 63.34 & 1002.8 \\
\hline 1200 Can Max Al, Na; Min Fe, Mn, Ni, U & 417 & 25 & 55 & & TL & -11.3949 & 30.82 & 724 & -10.5039 & 72.74 & 1001.9 \\
\hline 1200 Can Max Al, Na; Min Fe, Mn, Ni, U & 418 & 29 & 53 & hvisc & TL & -9.308 & 50.72 & 803.9 & -9.2605 & 100.19 & 1006.5 \\
\hline 1200 Can Max Al, Na; Min Fe, Mn, Ni, U & 425 & 25 & 54 & & TL & -10.7019 & 37.1 & 733.5 & -10.1086 & 83.23 & 1001.2 \\
\hline 1200 Can Max Al, Na; Min Fe, Mn, Ni, U & 426 & 25 & 54 & & TL & -10.0089 & 42.54 & 743.3 & -9.6835 & 94.89 & 1006.8 \\
\hline 1200 Can Max Al, Na; Min Fe, Mn, Ni, U & 431 & 25 & 53 & & lvisc & -12.7808 & 25.15 & 705.8 & -11.4318 & 54.94 & 978.1 \\
\hline 1200 Can Max Al, Na; Min Fe, Mn, Ni, U & 441 & 37 & 45 & Del Gp & lvisc & -13.3669 & 25.01 & 831.6 & -12.8337 & 31.5 & 905.6 \\
\hline 1200 Can Max Ni & 320 & 25 & 40 & & $\overline{\mathrm{TL}}$ & -12.7206 & 31.04 & 775.1 & -12.5162 & 52.32 & 997.6 \\
\hline 1200 Can Max Ni & 417 & 25 & 39 & & $\overline{T L}$ & -12.0276 & 37.5 & 787 & -11.9662 & 60.28 & 995.8 \\
\hline 1200 Can Max Ni & 418 & 25 & 36 & & TL & -10.2053 & 63.84 & 825.6 & -9.9487 & 90.16 & 992.4 \\
\hline 1200 Can Max Ni & 425 & 25 & 38 & & $\mathrm{TL}$ & -11.3977 & 45.03 & 799.4 & -11.3346 & 69.19 & 994.4 \\
\hline 1200 Can Max Ni & 426 & 25 & 37 & & TL & -10.8108 & 53.77 & 812.3 & -10.6417 & 79.12 & 993.2 \\
\hline 1200 Can Max Ni & 431 & 25 & 41 & & TL lvisc & -13.4136 & 25.53 & 763.5 & -13.0477 & 45.24 & 999.6 \\
\hline
\end{tabular}




\begin{tabular}{|c|c|c|c|c|c|c|c|c|c|c|c|}
\hline Type & $\begin{array}{l}\text { Frit } \\
\text { ID }\end{array}$ & $\begin{array}{l}\text { Min } \\
\text { WL }\end{array}$ & $\begin{array}{l}\text { Max } \\
\text { WL } \\
\end{array}$ & $\begin{array}{c}\text { Limited } \\
\text { Below By }\end{array}$ & $\begin{array}{c}\text { Limited } \\
\text { Above By }\end{array}$ & $\begin{array}{c}\text { Del Gp } \\
\text { (min) }\end{array}$ & $\begin{array}{c}\text { Visc } \\
\text { (min) }\end{array}$ & $\begin{array}{c}\text { TL } \\
\text { (min) }\end{array}$ & $\begin{array}{c}\text { Del Gp } \\
(\max )\end{array}$ & Visc (max) & TL (max) \\
\hline 1200 Can Max Ni & 441 & . & $\cdot$ & & & . & $\cdot$ & $\cdot$ & . & $\cdot$ & $\cdot$ \\
\hline 1200 Can Min Ce & 320 & 25 & 45 & & $\mathrm{TL}$ & -12.3425 & 33.08 & 753.6 & -11.7675 & 59.11 & 1002.3 \\
\hline 1200 Can Min Ce & 417 & 25 & 44 & & TL & -11.6495 & 39.71 & 764.2 & -11.2788 & 67.97 & 1001 \\
\hline 1200 Can Min Ce & 418 & 26 & 41 & hvisc & TL & -9.7019 & 66.48 & 813.6 & -9.5788 & 98.99 & 998.8 \\
\hline 1200 Can Min Ce & 425 & 25 & 43 & & TL & -10.9565 & 47.41 & 775.2 & -10.7717 & 77.86 & 1000 \\
\hline 1200 Can Min Ce & 426 & 25 & 42 & & TL & -10.2636 & 56.29 & 786.6 & -10.246 & 88.88 & 999.2 \\
\hline 1200 Can Min Ce & 431 & 25 & 46 & & $\mathrm{TL}$ & -13.0355 & 27.38 & 743.3 & -12.2377 & 51.2 & 1003.8 \\
\hline 1200 Can Min Ce & 441 & . & . & & & . & . & . & . & . & . \\
\hline 1200 Can Min Mg, Ti & 320 & 25 & 42 & & $\mathrm{TL}$ & -12.4624 & 33.93 & 769.9 & -12.0552 & 56.83 & 1003.7 \\
\hline 1200 Can Min Mg, Ti & 417 & 25 & 41 & & $\mathrm{TL}$ & -11.7695 & 40.75 & 781.2 & -11.534 & 65.4 & 1002.2 \\
\hline 1200 Can Min Mg, Ti & 418 & 25 & 38 & & $\mathrm{TL}$ & -9.8596 & 68.29 & 817.6 & -9.6905 & 97.48 & 999.2 \\
\hline 1200 Can Min Mg, Ti & 425 & 25 & 40 & & $\mathrm{TL}$ & -11.0765 & 48.67 & 792.9 & -10.9944 & 74.97 & 1000.9 \\
\hline 1200 Can Min Mg, Ti & 426 & 25 & 39 & & $\mathrm{TL}$ & -10.4362 & 57.8 & 805 & -10.3835 & 85.63 & 999.9 \\
\hline 1200 Can Min Mg, Ti & 431 & 25 & 42 & & TL & -13.1554 & 29.22 & 759 & -12.5911 & 49.2 & 994.1 \\
\hline 1200 Can Min Mg, Ti & 441 & . & . & & & . & . & . & . & . & . \\
\hline 1200 Can Max Mg, Ti & 320 & 25 & 51 & & lvisc & -12.2967 & 25.75 & 715.3 & -11.5016 & 59.17 & 982.3 \\
\hline 1200 Can Max Mg, Ti & 417 & 25 & 54 & & TL lvisc & -11.6037 & 25.65 & 724.9 & -10.9848 & 68.02 & 1009.7 \\
\hline 1200 Can Max Mg, Ti & 418 & 26 & 51 & hvisc & $\mathrm{TL}$ & -9.6905 & 45.17 & 769.1 & -9.5311 & 98.98 & 1008.4 \\
\hline 1200 Can Max Mg, Ti & 425 & 25 & 53 & & $\mathrm{TL}$ & -10.9107 & 31.17 & 734.7 & -10.5718 & 77.89 & 1009 \\
\hline 1200 Can Max Mg, Ti & 426 & 25 & 52 & & TL & -10.2178 & 37.64 & 744.9 & -10.1404 & 88.89 & 1008.6 \\
\hline 1200 Can Max Mg, Ti & 431 & 25 & 48 & & lvisc & -12.9897 & 25.39 & 706 & -12.0738 & 51.28 & 952.5 \\
\hline 1200 Can Max Mg, Ti & 441 & . & . & & & . & . & . & . & . & . \\
\hline
\end{tabular}


Table A2. MAR Results and Various Predicted Properties for the “1 Less Washed” SB4 Blending Options.

\begin{tabular}{|c|c|c|c|c|c|c|c|c|c|c|c|}
\hline Type & $\begin{array}{l}\text { Frit } \\
\text { ID }\end{array}$ & $\begin{array}{l}\text { Min } \\
\text { WL }\end{array}$ & $\begin{array}{l}\text { Max } \\
\text { WL }\end{array}$ & $\begin{array}{c}\text { Limited } \\
\text { Below By }\end{array}$ & $\begin{array}{c}\text { Limited } \\
\text { Above By }\end{array}$ & $\begin{array}{c}\text { Del Gp } \\
\text { (min) }\end{array}$ & $\begin{array}{c}\text { Visc } \\
\text { (min) }\end{array}$ & $\begin{array}{c}\text { TL } \\
\text { (min) }\end{array}$ & $\begin{array}{c}\text { Del Gp } \\
(\max )\end{array}$ & $\begin{array}{c}\text { Visc } \\
(\max )\end{array}$ & $\begin{array}{c}\text { TL } \\
(\max )\end{array}$ \\
\hline SB4 Only Baseline (1 less wash) & 320 & 25 & 42 & & $\mathrm{TL}$ & -12.2102 & 40.84 & 771.7 & -11.6314 & 61.97 & 995.9 \\
\hline SB4 Only Baseline (1 less wash) & 417 & 25 & 41 & & TL & -11.5172 & 48.59 & 782.6 & -11.1203 & 71.23 & 994.3 \\
\hline SB4 Only Baseline (1 less wash) & 418 & 28 & 38 & hvisc & TL & -9.4761 & 79.31 & 863.2 & -9.4469 & 99.89 & 991.1 \\
\hline SB4 Only Baseline (1 less wash) & 425 & 25 & 40 & & $\mathrm{TL}$ & -10.8242 & 57.49 & 793.8 & -10.5907 & 81.56 & 992.9 \\
\hline SB4 Only Baseline (1 less wash) & 426 & 25 & 39 & & $\mathrm{TL}$ & -10.1312 & 67.69 & 805.4 & -10.0426 & 93.07 & 991.9 \\
\hline SB4 Only Baseline (1 less wash) & 431 & 25 & 43 & & $\mathrm{TL}$ & -12.9031 & 34.14 & 761.1 & -12.124 & 53.71 & 997.7 \\
\hline SB4 Only Baseline (1 less wash) & 441 & 40 & 43 & Del Gp & lvisc & -13.3626 & 25.11 & 946.7 & -13.1773 & 27.62 & 980.5 \\
\hline SB4 Only Min Al, Na, Mg, Ti; Max Ce, Fe, Mg, Ni, U (1 less wash) & 320 & 25 & 37 & & $\overline{\mathrm{TL}}$ & -12.5502 & 39.59 & 796.8 & -12.3049 & 56.06 & 985.3 \\
\hline SB4 Only Min Al, Na, Mg, Ti; Max Ce, Fe, Mg, Ni, U (1 less wash) & 417 & 25 & 37 & & $\mathrm{TL}$ & -11.8572 & 45.74 & 809 & -11.7228 & 64.54 & 997 \\
\hline SB4 Only Min Al, Na, Mg, Ti; Max Ce, Fe, Mg, Ni, U (1 less wash) & 418 & 25 & 34 & & TL & -9.9269 & 75.83 & 848.4 & -9.7783 & 96.32 & 992.1 \\
\hline SB4 Only Min Al, Na, Mg, Ti; Max Ce, Fe, Mg, Ni, U (1 less wash) & 425 & 25 & 36 & & $\mathrm{TL}$ & -11.1642 & 54.43 & 821.7 & -11.1426 & 74.02 & 995 \\
\hline SB4 Only Min Al, Na, Mg, Ti; Max Ce, Fe, Mg, Ni, U (1 less wash) & 426 & 25 & 35 & & $\mathrm{TL}$ & -10.544 & 64.41 & 834.8 & -10.4712 & 84.59 & 993.4 \\
\hline SB4 Only Min Al, Na, Mg, Ti; Max Ce, Fe, Mg, Ni, U (1 less wash) & 431 & 25 & 38 & & TL & -13.2432 & 32.94 & 785 & -12.8573 & 48.51 & 987.9 \\
\hline SB4 Only Min Al, Na, Mg, Ti; Max Ce, Fe, Mg, Ni, U (1 less wash) & 441 & . & . & & & . & . & . & . & . & . \\
\hline SB4 Only Max Al, Na, Mg, Ti; Min Ce, Fe, Mn, Ni, U (1 less wash) & 320 & 25 & 60 & & & -11.2478 & 66.53 & 707 & -8.709 & 83.27 & 954.9 \\
\hline SB4 Only Max Al, Na, Mg, Ti; Min Ce, Fe, Mn, Ni, U (1 less wash) & 417 & 25 & 60 & & & -10.5548 & 75.84 & 715 & -8.3394 & 95.28 & 958 \\
\hline SB4 Only Max Al, Na, Mg, Ti; Min Ce, Fe, Mn, Ni, U (1 less wash) & 418 & & . & & & . & . & . & . & . & . \\
\hline SB4 Only Max Al, Na, Mg, Ti; Min Ce, Fe, Mn, Ni, U (1 less wash) & 425 & 43 & 60 & hvisc & & -8.8888 & 86.16 & 879.7 & -7.9698 & 99.64 & 961 \\
\hline SB4 Only Max Al, Na, Mg, Ti; Min Ce, Fe, Mn, Ni, U (1 less wash) & 426 & . & . & & & . & . & . & . & . & . \\
\hline SB4 Only Max Al, Na, Mg, Ti; Min Ce, Fe, Mn, Ni, U (1 less wash) & 431 & 25 & 60 & & & -11.9408 & 58.17 & 699.3 & -9.0786 & 72.51 & 951.9 \\
\hline SB4 Only Max Al, Na, Mg, Ti; Min Ce, Fe, Mn, Ni, U (1 less wash) & 441 & 25 & 60 & & & -13.3268 & 43.98 & 684.2 & -9.8178 & 54.33 & 945.8 \\
\hline 1100 Can Baseline (1 less wash) & 320 & 25 & 41 & & lvisc & -13.372 & 24.64 & 723.4 & -13.2507 & 47.73 & 929.8 \\
\hline 1100 Can Baseline (1 less wash) & 417 & 25 & 43 & & lvisc & -12.8605 & 25.74 & 734.1 & -12.5578 & 55.04 & 960.4 \\
\hline 1100 Can Baseline (1 less wash) & 418 & 25 & 45 & & $\mathrm{TL}$ & -11.3695 & 35.41 & 768.5 & -10.4788 & 82.56 & 1008.7 \\
\hline 1100 Can Baseline (1 less wash) & 425 & 25 & 46 & & lvisc & -12.412 & 25.12 & 745.2 & -11.8648 & 63.23 & 999.5 \\
\hline 1100 Can Baseline (1 less wash) & 426 & 25 & 46 & & $\mathrm{TL}$ & -11.913 & 29.03 & 756.6 & -11.1718 & 72.38 & 1008.7 \\
\hline 1100 Can Baseline (1 less wash) & 431 & . & . & & & . & . & . & . & . & . \\
\hline 1100 Can Baseline (1 less wash) & 441 & & . & & & . & . & . & . & . & . \\
\hline
\end{tabular}




\begin{tabular}{|c|c|c|c|c|c|c|c|c|c|c|c|}
\hline Type & $\begin{array}{l}\text { Frit } \\
\text { ID }\end{array}$ & $\begin{array}{l}\text { Min } \\
\text { WL }\end{array}$ & $\begin{array}{l}\text { Max } \\
\text { WL }\end{array}$ & $\begin{array}{c}\text { Limited } \\
\text { Below By }\end{array}$ & $\begin{array}{c}\text { Limited } \\
\text { Above By }\end{array}$ & $\begin{array}{c}\text { Del Gp } \\
\text { (min) }\end{array}$ & $\begin{array}{c}\text { Visc } \\
\text { (min) }\end{array}$ & $\begin{array}{c}\text { TL } \\
\text { (min) }\end{array}$ & $\begin{array}{c}\text { Del Gp } \\
\text { (max) }\end{array}$ & $\begin{array}{c}\text { Visc } \\
\text { (max) }\end{array}$ & $\begin{array}{c}\text { TL } \\
(\max )\end{array}$ \\
\hline 1100 Can 2nd Transfer, Baseline (1 less wash) & 320 & 25 & 43 & & lvisc & -13.0666 & 25.42 & 734.3 & -13.0644 & 50.81 & 962.7 \\
\hline 1100 Can 2nd Transfer, Baseline (1 less wash) & 417 & 25 & 46 & & TL lvisc & -12.568 & 25.25 & 745 & -12.3714 & 58.55 & 1001.8 \\
\hline 1100 Can 2nd Transfer, Baseline (1 less wash) & 418 & 25 & 43 & & $\mathrm{TL}$ & -10.9599 & 45.1 & 779.3 & -10.2924 & 87.62 & 1000.3 \\
\hline 1100 Can 2nd Transfer, Baseline (1 less wash) & 425 & 25 & 45 & & TL & -12.0504 & 30.84 & 756 & -11.6784 & 67.21 & 1001 \\
\hline 1100 Can 2nd Transfer, Baseline (1 less wash) & 426 & 25 & 44 & & $\mathrm{TL}$ & -11.5144 & 37.41 & 767.4 & -10.9854 & 76.88 & 1000.5 \\
\hline 1100 Can 2nd Transfer, Baseline (1 less wash) & 431 & . & . & & & . & . & . & . & . & . \\
\hline 1100 Can 2nd Transfer, Baseline (1 less wash) & 441 & . & . & & & . & . & . & . & . & . \\
\hline 1100 Can Min Al, Na; Max Ce, Fe, Mn, U (1 less wash) & 320 & . & . & & & . & . & . & . & . & . \\
\hline 1100 Can Min Al, Na; Max Ce, Fe, Mn, U (1 less wash) & 417 & 25 & 41 & & lvisc & -13.1562 & 25.19 & 739 & -12.7586 & 51.75 & 953.4 \\
\hline 1100 Can Min Al, Na; Max Ce, Fe, Mn, U (1 less wash) & 418 & 25 & 43 & & $\overline{T L}$ & -11.6259 & 34.62 & 775.1 & -10.6796 & 77.83 & 1007.2 \\
\hline 1100 Can Min Al, Na; Max Ce, Fe, Mn, U (1 less wash) & 425 & 25 & 44 & & lvisc & -12.7133 & 24.48 & 750.6 & -12.0656 & 59.51 & 996.8 \\
\hline 1100 Can Min Al, Na; Max Ce, Fe, Mn, U (1 less wash) & 426 & 25 & 44 & & TL & -12.1959 & 28.31 & 762.7 & -11.3726 & 68.18 & 1007.1 \\
\hline 1100 Can Min Al, Na; Max Ce, Fe, Mn, U (1 less wash) & 431 & . & . & & & . & . & . & . & . & . \\
\hline 1100 Can Min Al, Na; Max Ce, Fe, Mn, U (1 less wash) & 441 & . & . & & & . & . & . & . & . & . \\
\hline 1100 Can Max Al, Na; Min Mn, Ni, U (1 less wash) & 320 & 25 & 49 & & lvisc & -12.7116 & 24.9 & 699.2 & -12.3759 & 56.61 & 939.1 \\
\hline 1100 Can Max Al, Na; Min Mn, Ni, U (1 less wash) & 417 & 25 & 51 & & lvisc & -12.0186 & 26.08 & 708.3 & -11.8951 & 65.11 & 959.4 \\
\hline 1100 Can Max Al, Na; Min Mn, Ni, U (1 less wash) & 418 & 25 & 56 & & $\mathrm{TL}$ & -10.6517 & 30 & 737.6 & -9.9396 & 96.95 & 1008.1 \\
\hline 1100 Can Max Al, Na; Min Mn, Ni, U (1 less wash) & 425 & 25 & 54 & & lvisc & -11.4559 & 25.54 & 717.8 & -11.3256 & 74.61 & 984.9 \\
\hline 1100 Can Max Al, Na; Min Mn, Ni, U (1 less wash) & 426 & 25 & 56 & & lvisc & -11.0583 & 26.1 & 727.5 & -10.6326 & 85.2 & 1002.6 \\
\hline 1100 Can Max Al, Na; Min Mn, Ni, U (1 less wash) & 431 & 25 & 46 & & lvisc & -13.4046 & 24.64 & 690.3 & -12.9168 & 49.02 & 909.7 \\
\hline 1100 Can Max Al, Na; Min Mn, Ni, U (1 less wash) & 441 & & & & & . & $\cdot$ & . & . & . & . \\
\hline 1100 Can Min Ce, Mg, Ti (1 less wash) & 320 & 25 & 44 & & TL & -12.9421 & 26.83 & 752 & -12.8515 & 53.19 & 998.6 \\
\hline 1100 Can Min Ce, Mg, Ti (1 less wash) & 417 & 25 & 43 & & $\mathrm{TL}$ & -12.3296 & 32.6 & 763 & -12.2491 & 61.26 & 997.3 \\
\hline 1100 Can Min Ce, Mg, Ti (1 less wash) & 418 & 25 & 40 & & $\overline{\mathrm{TL}}$ & -10.653 & 56.35 & 798.1 & -10.1701 & 91.56 & 995 \\
\hline 1100 Can Min Ce, Mg, Ti (1 less wash) & 425 & 25 & 42 & & $\overline{T L}$ & -11.7892 & 39.36 & 774.3 & -11.5561 & 70.29 & 996.2 \\
\hline 1100 Can Min Ce, Mg, Ti (1 less wash) & 426 & 25 & 41 & & $\overline{T L}$ & -11.2303 & 47.23 & 786 & -10.8631 & 80.36 & 995.5 \\
\hline 1100 Can Min Ce, Mg, Ti (1 less wash) & 431 & 41 & 42 & Del Gp & lvisc & -13.4109 & 25.28 & 956.5 & -13.3969 & 26.42 & 967.7 \\
\hline 1100 Can Min Ce, Mg, Ti (1 less wash) & 441 & . & . & & & . & . & . & . & . & . \\
\hline 1100 Can Min Fe (1 less wash) & 320 & 25 & 47 & & lvisc & -12.8542 & 24.95 & 735.2 & -12.6719 & 54.73 & 994 \\
\hline 1100 Can Min Fe (1 less wash) & 417 & 25 & 47 & & $\overline{T L}$ & -12.1822 & 28.94 & 745.5 & -12.1612 & 63 & 1001.9 \\
\hline
\end{tabular}




\begin{tabular}{|c|c|c|c|c|c|c|c|c|c|c|c|}
\hline Type & $\begin{array}{l}\text { Frit } \\
\text { ID }\end{array}$ & $\begin{array}{l}\text { Min } \\
\text { WL }\end{array}$ & $\begin{array}{l}\text { Max } \\
\text { WL }\end{array}$ & $\begin{array}{c}\text { Limited } \\
\text { Below By }\end{array}$ & $\begin{array}{c}\text { Limited } \\
\text { Above By }\end{array}$ & $\begin{array}{c}\text { Del Gp } \\
\text { (min) }\end{array}$ & $\begin{array}{c}\text { Visc } \\
\text { (min) }\end{array}$ & $\begin{array}{c}\text { TL } \\
\text { (min) }\end{array}$ & $\begin{array}{c}\text { Del Gp } \\
\text { (max) }\end{array}$ & $\begin{array}{c}\text { Visc } \\
\text { (max) }\end{array}$ & $\begin{array}{c}\text { TL } \\
\text { (max) }\end{array}$ \\
\hline 1100 Can Min Fe (1 less wash) & 418 & 25 & 44 & & $\mathrm{TL}$ & -10.627 & 50.6 & 778.6 & -10.0822 & 94.01 & 1000.3 \\
\hline 1100 Can Min Fe (1 less wash) & 425 & 25 & 46 & & $\mathrm{TL}$ & -11.6823 & 35.08 & 756.2 & -11.4682 & 72.25 & 1001.1 \\
\hline 1100 Can Min Fe (1 less wash) & 426 & 25 & 45 & & TL & -11.1639 & 42.26 & 767.2 & -10.7752 & 82.56 & 1000.6 \\
\hline 1100 Can Min Fe (1 less wash) & 431 & 33 & 44 & Del Gp & lvisc & -13.407 & 24.7 & 835.3 & -13.2142 & 37.57 & 957.4 \\
\hline 1100 Can Min Fe (1 less wash) & 441 & . & . & & & . & . & . & . & . & . \\
\hline 1100 Can Max Mg (1 less wash) & 320 & 25 & 34 & & Del Gp & -13.4239 & 33.1 & 723.5 & -13.3279 & 46.76 & 849.2 \\
\hline 1100 Can Max Mg (1 less wash) & 417 & 25 & 43 & & lvisc & -12.9932 & 24.6 & 734.4 & -12.6349 & 53.94 & 963.2 \\
\hline 1100 Can Max Mg (1 less wash) & 418 & 25 & 44 & & $\mathrm{TL}$ & -11.4608 & 35.79 & 769.2 & -10.5559 & 80.96 & 1002.8 \\
\hline 1100 Can Max Mg (1 less wash) & 425 & 25 & 45 & & lvisc & -12.5248 & 25.39 & 745.6 & -11.9419 & 61.98 & 993.2 \\
\hline 1100 Can Max Mg (1 less wash) & 426 & 25 & 45 & & $\overline{\mathrm{TL}}$ & -12.0166 & 29.35 & 757.1 & -11.2489 & 70.96 & 1002.8 \\
\hline 1100 Can Max Mg (1 less wash) & 431 & . & . & & & . & . & . & . & . & . \\
\hline 1100 Can Max Mg (1 less wash) & 441 & . & . & & & . & . & . & . & . & . \\
\hline 1100 Can Max Ni (1 less wash) & 320 & 25 & 42 & & TL lvisc & -13.309 & 24.45 & 755.2 & -13.2087 & 48.8 & 992.4 \\
\hline 1100 Can Max Ni (1 less wash) & 417 & 25 & 42 & & TL & -12.7731 & 28.41 & 766.8 & -12.5157 & 56.28 & 1002.8 \\
\hline 1100 Can Max Ni (1 less wash) & 418 & 25 & 39 & & $\overline{\mathrm{TL}}$ & -11.0368 & 50.21 & 803.9 & -10.4368 & 84.41 & 1000.7 \\
\hline 1100 Can Max Ni (1 less wash) & 425 & 25 & 41 & & $\overline{T L}$ & -12.2128 & 34.56 & 778.7 & -11.8227 & 64.65 & 1001.8 \\
\hline 1100 Can Max Ni (1 less wash) & 426 & 25 & 40 & & $\overline{T L}$ & -11.634 & 41.79 & 791.1 & -11.1298 & 74 & 1001 \\
\hline 1100 Can Max Ni (1 less wash) & 431 & . & . & & & . & . & . & . & . & . \\
\hline 1100 Can Max Ni (1 less wash) & 441 & . & . & & & . & . & . & . & . & . \\
\hline 1100 Can Max Ti (1 less wash) & 320 & 25 & 45 & & lvisc & -12.9165 & 25.44 & 698.9 & -12.8007 & 52.94 & 915.8 \\
\hline 1100 Can Max Ti (1 less wash) & 417 & 25 & 48 & & lvisc & -12.3029 & 25.3 & 708.3 & -12.2235 & 60.95 & 947.3 \\
\hline 1100 Can Max Ti (1 less wash) & 418 & 25 & 54 & & TL & -11.0485 & 27.22 & 738.6 & -10.1446 & 90.99 & 1009.6 \\
\hline 1100 Can Max Ti (1 less wash) & 425 & 25 & 50 & & lvisc & -11.8478 & 26.2 & 718.1 & -11.5306 & 69.9 & 969.2 \\
\hline 1100 Can Max Ti (1 less wash) & 426 & 25 & 53 & & lvisc & -11.4516 & 25.22 & 728.2 & -10.8376 & 79.89 & 996.8 \\
\hline 1100 Can Max Ti (1 less wash) & 431 & 38 & 42 & Del Gp & lvisc & -13.4141 & 25.17 & 843.5 & -13.354 & 29.79 & 881.9 \\
\hline 1100 Can Max Ti (1 less wash) & 441 & . & . & & & . & . & . & . & . & . \\
\hline 1200 Can Baseline (1 less wash) & 320 & 25 & 42 & & lvisc & -13.179 & 25.49 & 730.4 & -13.1314 & 49.71 & 948 \\
\hline 1200 Can Baseline (1 less wash) & 417 & 25 & 45 & & lvisc & -12.6792 & 25.3 & 741.1 & -12.4384 & 57.29 & 987.9 \\
\hline 1200 Can Baseline (1 less wash) & 418 & 25 & 44 & & TL & -11.1149 & 40.94 & 775.4 & -10.3594 & 85.82 & 1006.1 \\
\hline 1200 Can Baseline (1 less wash) & 425 & 25 & 46 & & $\mathrm{TL}$ & -12.1923 & 27.73 & 752.1 & -11.7454 & 65.79 & 1006.7 \\
\hline
\end{tabular}




\begin{tabular}{|c|c|c|c|c|c|c|c|c|c|c|c|}
\hline Type & $\begin{array}{l}\text { Frit } \\
\text { ID }\end{array}$ & $\begin{array}{l}\text { Min } \\
\text { WL }\end{array}$ & $\begin{array}{l}\text { Max } \\
\text { WL } \\
\end{array}$ & $\begin{array}{c}\text { Limited } \\
\text { Below By }\end{array}$ & $\begin{array}{c}\text { Limited } \\
\text { Above By }\end{array}$ & $\begin{array}{c}\begin{array}{c}\text { Del Gp } \\
\text { (min) }\end{array} \\
\end{array}$ & $\begin{array}{c}\text { Visc } \\
\text { (min) }\end{array}$ & $\begin{array}{c}\text { TL } \\
(\min )\end{array}$ & $\begin{array}{c}\begin{array}{c}\text { Del Gp } \\
(\max )\end{array} \\
\end{array}$ & $\begin{array}{c}\text { Visc } \\
(\mathbf{m a x})\end{array}$ & $\begin{array}{c}\mathrm{TL} \\
(\mathbf{m a x})\end{array}$ \\
\hline 1200 Can Baseline (1 less wash) & 426 & 25 & 45 & & $\mathrm{TL}$ & -11.6628 & 33.8 & 763.5 & -11.0524 & 75.27 & 1006.2 \\
\hline 1200 Can Baseline (1 less wash) & 431 & e & . & & & . & . & . & . & . & . \\
\hline 1200 Can Baseline (1 less wash) & 441 & & . & & & . & . & . & . & . & . \\
\hline 1200 Can 2nd Transfer, Baseline (1 less wash) & 320 & 25 & 44 & & lvisc & -13.0329 & 24.79 & 736 & -13.0114 & 51.37 & 974.7 \\
\hline 1200 Can 2nd Transfer, Baseline (1 less wash) & 417 & 25 & 46 & & TL lvisc & -12.5102 & 25.95 & 746.7 & -12.3399 & 59.19 & 1003.3 \\
\hline 1200 Can 2nd Transfer, Baseline (1 less wash) & 418 & 25 & 43 & & TL & -10.9058 & 46.16 & 780.9 & -10.261 & 88.55 & 1001.8 \\
\hline 1200 Can 2nd Transfer, Baseline (1 less wash) & 425 & 25 & 45 & & $\mathrm{TL}$ & -11.9939 & 31.65 & 757.7 & -11.647 & 67.94 & 1002.5 \\
\hline 1200 Can 2nd Transfer, Baseline (1 less wash) & 426 & 25 & 44 & & $\mathrm{TL}$ & -11.4591 & 38.34 & 769.1 & -10.954 & 77.7 & 1002 \\
\hline 1200 Can 2nd Transfer, Baseline (1 less wash) & 431 & & . & & & . & . & . & . & . & . \\
\hline 1200 Can 2nd Transfer, Baseline (1 less wash) & 441 & . & . & & & . & . & . & . & . & . \\
\hline 1200 Can Min Al, Na; Max Ce, Fe, Mn, U (1 less wash) & 320 & 25 & 30 & & Del Gp & -13.4256 & 38.44 & 737.6 & -13.3649 & 46.25 & 813.7 \\
\hline 1200 Can Min Al, Na; Max Ce, Fe, Mn, U (1 less wash) & 417 & 25 & 42 & & lvisc & -13.0354 & 25.38 & 748.9 & -12.6719 & 53.36 & 978.4 \\
\hline 1200 Can Min Al, Na; Max Ce, Fe, Mn, U (1 less wash) & 418 & 25 & 41 & & TL & -11.3785 & 41.17 & 785.4 & -10.5929 & 80.17 & 999.5 \\
\hline 1200 Can Min Al, Na; Max Ce, Fe, Mn, U (1 less wash) & 425 & 25 & 43 & & TL & -12.5301 & 27.8 & 760.7 & -11.9789 & 61.34 & 1000 \\
\hline 1200 Can Min Al, Na; Max Ce, Fe, Mn, U (1 less wash) & 426 & 25 & 42 & & $\mathrm{TL}$ & -11.9636 & 33.94 & 772.8 & -11.2859 & 70.25 & 999.5 \\
\hline 1200 Can Min Al, Na; Max Ce, Fe, Mn, U (1 less wash) & 431 & & . & & & . & . & . & . & . & . \\
\hline 1200 Can Min Al, Na; Max Ce, Fe, Mn, U (1 less wash) & 441 & 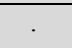 & . & & & . & . & . & . & . & . \\
\hline 1200 Can Max Al, Na; Min Fe, Mn, Ni, U (1 less wash) & 320 & 25 & 51 & & lvisc & -12.5951 & 25.27 & 698.9 & -12.1102 & 58.82 & 947.2 \\
\hline 1200 Can Max Al, Na; Min Fe, Mn, Ni, U (1 less wash) & 417 & 25 & 54 & & lvisc & -11.9021 & 25.13 & 707.9 & -11.6293 & 67.63 & 972.1 \\
\hline 1200 Can Max Al, Na; Min Fe, Mn, Ni, U (1 less wash) & 418 & 26 & 57 & hvisc & TL & -10.4091 & 32.37 & 749.5 & -9.8414 & 98.42 & 1005 \\
\hline 1200 Can Max Al, Na; Min Fe, Mn, Ni, U (1 less wash) & 425 & 25 & 56 & & lvisc & -11.2091 & 25.97 & 717.2 & -11.2039 & 77.46 & 989.2 \\
\hline 1200 Can Max Al, Na; Min Fe, Mn, Ni, U (1 less wash) & 426 & 25 & 58 & & TL lvisc & -10.8155 & 26.53 & 726.8 & -10.5161 & 88.4 & 1005.3 \\
\hline 1200 Can Max Al, Na; Min Fe, Mn, Ni, U (1 less wash) & 431 & 25 & 48 & & lvisc & -13.2881 & 24.97 & 690.2 & -12.6467 & 50.97 & 920.1 \\
\hline 1200 Can Max Al, Na; Min Fe, Mn, Ni, U (1 less wash) & 441 & . & . & & & $\cdot$ & $\cdot$ & $\cdot$ & $\cdot$ & . & $\cdot$ \\
\hline 1200 Can Max Ni (1 less wash) & 320 & 25 & 42 & & TL lvisc & -13.3056 & 24.5 & 755.4 & -13.2067 & 48.86 & 992.6 \\
\hline 1200 Can Max Ni (1 less wash) & 417 & 25 & 42 & & $\mathrm{TL}$ & -12.7697 & 28.47 & 766.9 & -12.5138 & 56.34 & 1003 \\
\hline 1200 Can Max Ni (1 less wash) & 418 & 25 & 39 & & TL & -11.0337 & 50.31 & 804.1 & -10.4348 & 84.5 & 1000.9 \\
\hline 1200 Can Max Ni (1 less wash) & 425 & 25 & 41 & & $\mathrm{TL}$ & -12.2095 & 34.64 & 778.9 & -11.8208 & 64.72 & 1002 \\
\hline 1200 Can Max Ni (1 less wash) & 426 & 25 & 40 & & $\mathrm{TL}$ & -11.6308 & 41.87 & 791.3 & -11.1278 & 74.08 & 1001.2 \\
\hline 1200 Can Max Ni (1 less wash) & 431 & & 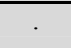 & & & . & . & . & . & . & . \\
\hline
\end{tabular}


WSRC-TR-2005-00103

Revision 0

\begin{tabular}{|c|c|c|c|c|c|c|c|c|c|c|c|}
\hline Type & $\begin{array}{c}\text { Frit } \\
\text { ID }\end{array}$ & $\begin{array}{l}\text { Min } \\
\text { WL }\end{array}$ & $\begin{array}{l}\text { Max } \\
\text { WL }\end{array}$ & $\begin{array}{c}\text { Limited } \\
\text { Below By }\end{array}$ & $\begin{array}{c}\text { Limited } \\
\text { Above By }\end{array}$ & $\begin{array}{c}\text { Del Gp } \\
\text { (min) }\end{array}$ & $\begin{array}{c}\text { Visc } \\
\text { (min) }\end{array}$ & $\begin{array}{c}\text { TL } \\
\text { (min) }\end{array}$ & $\begin{array}{r}\text { Del Gp } \\
\text { (max) }\end{array}$ & $\begin{array}{c}\text { Visc } \\
(\max )\end{array}$ & $\begin{array}{c}\text { TL } \\
(\max )\end{array}$ \\
\hline 1200 Can Max Ni (1 less wash) & 441 & . & . & & & . &. & . & . &. & \\
\hline 1200 Can Min Ce (1 less wash) & 320 & 25 & 47 & & lvisc & -12.8408 & 25.28 & 735.7 & -12.6467 & 55 & 994.2 \\
\hline 1200 Can Min Ce (1 less wash) & 417 & 25 & 47 & & TL & -12.157 & 29.32 & 746 & -12.1478 & 63.31 & 1002.1 \\
\hline 1200 Can Min Ce (1 less wash) & 418 & 25 & 44 & & TL & -10.6034 & 51.16 & 779 & -10.0688 & 94.45 & 1000.5 \\
\hline 1200 Can Min Ce (1 less wash) & 425 & 25 & 46 & & $\mathrm{TL}$ & -11.6576 & 35.51 & 756.6 & -11.4548 & 72.6 & 1001.3 \\
\hline 1200 Can Min Ce (1 less wash) & 426 & 25 & 45 & & TL & -11.1398 & 42.75 & 767.6 & -10.7618 & 82.95 & 1000.8 \\
\hline 1200 Can Min Ce (1 less wash) & 431 & 32 & 44 & Del Gp & lvisc & -13.4073 & 24.99 & 823.1 & -13.1906 & 39.06 & 957.7 \\
\hline 1200 Can Min Ce (1 less wash) & 441 & . & . & & & . & . & . & . & . & . \\
\hline 1200 Can Min Mg, Ti (1 less wash) & 320 & 25 & 44 & & $\mathrm{TL}$ & -12.9563 & 26.55 & 751 & -12.8765 & 52.94 & 997.5 \\
\hline 1200 Can Min Mg, Ti (1 less wash) & 417 & 25 & 43 & & $\overline{T L}$ & -12.354 & 32.28 & 762 & -12.2633 & 60.98 & 996.1 \\
\hline 1200 Can Min Mg, Ti (1 less wash) & 418 & 25 & 40 & & $\mathrm{TL}$ & -10.6757 & 55.87 & 797.1 & -10.1843 & 91.16 & 993.9 \\
\hline 1200 Can Min Mg, Ti (1 less wash) & 425 & 25 & 42 & & $\mathrm{TL}$ & -11.8131 & 38.99 & 773.3 & -11.5703 & 69.98 & 995.1 \\
\hline 1200 Can Min Mg, Ti (1 less wash) & 426 & 25 & 41 & & $\mathrm{TL}$ & -11.2536 & 46.81 & 785 & -10.8773 & 80.01 & 994.3 \\
\hline 1200 Can Min Mg, Ti (1 less wash) & 431 & . & . & & & . & . & . & . & . & . \\
\hline 1200 Can Min Mg, Ti (1 less wash) & 441 & . & . & & & . & . & . & . & . & . \\
\hline 1200 Can Max Mg, Ti (1 less wash) & 320 & 25 & 47 & & lvisc & -12.7979 & 25.46 & 699 & -12.5661 & 55.06 & 927.7 \\
\hline 1200 Can Max Mg, Ti (1 less wash) & 417 & 25 & 50 & & lvisc & -12.1049 & 25.34 & 708.3 & -12.0725 & 63.35 & 956.8 \\
\hline 1200 Can Max Mg, Ti (1 less wash) & 418 & 25 & 55 & & $\mathrm{TL}$ & -10.8187 & 29.04 & 738 & -10.026 & 94.43 & 1008.2 \\
\hline 1200 Can Max Mg, Ti (1 less wash) & 425 & 25 & 52 & & lvisc & -11.6264 & 26.24 & 717.9 & -11.4119 & 72.62 & 977.1 \\
\hline 1200 Can Max Mg, Ti (1 less wash) & 426 & 25 & 55 & & lvisc & -11.2345 & 25.25 & 727.8 & -10.7189 & 82.95 & 1002.4 \\
\hline 1200 Can Max Mg, Ti (1 less wash) & 431 & 29 & 44 & Del Gp & lvisc & -13.4118 & 25.16 & 742.1 & -13.1152 & 42.79 & 896.2 \\
\hline 1200 Can Max Mg, Ti (1 less wash) & 441 & . & . & & & . & . & . & . & . & . \\
\hline
\end{tabular}




\section{Distribution:}

J.E. Marra, 773-A

E.W. Holtzscheiter, 773-A

D.A. Crowley, 999-W

S.L. Marra, 999-W

T.B. Calloway, 999-W

N.E. Bibler, 773-A

C.M. Jantzen, 773-A

J.R. Harbour, 773-42A

G.G. Wicks, 773-A

D.K. Peeler, 999-W

T.B. Edwards, 773-42A

C.C. Herman, 773-42A

A.S. Choi, 999-W

M.E. Smith, 773-42A

M.E. Stone, 999-W

D.H. Miller, 999-W
T.M. Jones, 999-W

M.S. Miller, 704-S

T.H. Lorier, 999-W

J.E. Occhipinti, 704-S

R.M. Hoeppel, 704-27S

J.F. Iaukea, 704-30S

J.W. Ray, 704-S

F.A. Washburn, 704-27S

H.H. Elder, 766-H

G.R. Lilliston, 776-H

D.C. Bumgardner, 766-H

J.M. Gillam, 766-H

W.B. Van Pelt, 704-S

H. B. Shah, 766-H 